ucanate

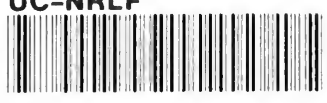

\$ 179536 

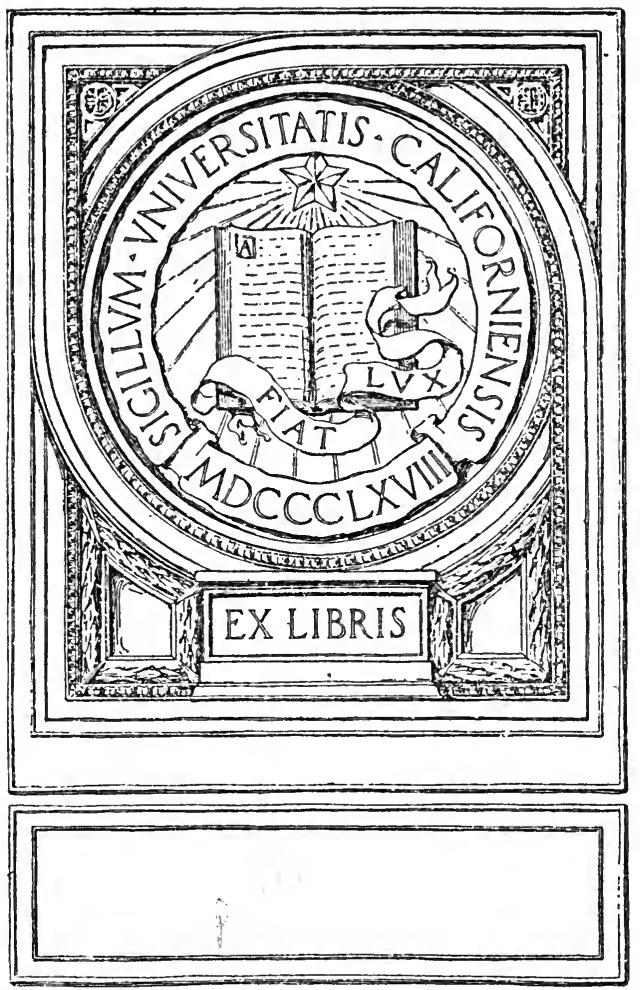
*

$+4$

\section{$+*$}

\section{$+$}

*

\section{* *}

iv

样

+

* *

\section{$++$}

样

*

* +

* +

* * *

*

** $+*$

*

* * *

*

$+$

$+$

*) $\rightarrow x^{2}-4 x^{2}$

政

*

*

*

*

4

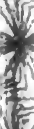

$+$

* *

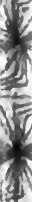

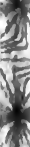

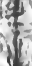

$+$

* + +

\section{$+$}

* *

* * * $+*+$

$*+*$

$+*+*+*+$

$*$

* * * * * * *

* * * * + * *

* * * * * *

$*$

$+*$

$+*+$

* * * * * *

* * * * * +

$+*+\ldots+\ldots$

* $+*+*+$

$+++*++$

$+, *+* *+*$

* * + * * * * *

*

$+*$

$+*+*+$

$+$

* * * * * * *

* * * * * *

*

$* *+$

$+\ldots$

$++*+$

$*+* * *+$

* * * * * * +

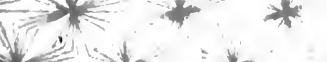

gis $*$

2

(

* *

* *

$+t$

$+$

to 4

*

th

*

$+\quad+$

$+$

$4 * *+$

$+$

$+$

$+*$

(t)

$+*$

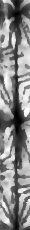

*

$+4$

* *

*

$+$

$+$

* * * * * 



\title{
THE DISTRIBUTION OF INCOMES IN THE UNITED STATES
}

\author{
BY \\ FRANK HATCH STREIGHTOFF, M. A. \\ Instructor in Economics, DePauw University \\ Sometime University Fellow, Columbia University \\ Author of The Standard of Living
}

\author{
SUBMTTTED IN PARTIAL FULFILMENT OF THE REQUIREMENTS \\ FOR THE DEGREE OF DOCTOR OF PHILOSOPHY \\ IN THE \\ Faculty of Political Science \\ in Columbia University
}

NEW YORK

I9I 2 
$H B .5$

Copyright, IgI2 BY

FRANK HATCH STREIGHTOFF

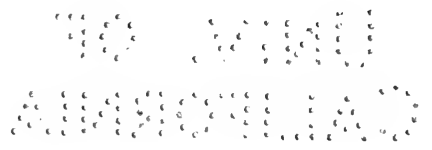




\section{PREFACE}

To Professors Edwin R. A. Seligman, Henry R. Seager, Henry L. Moore, and Robert E. Chaddock, the writer is indebted for much help in the preparation of this monograph. Especially is he grateful to Professor Seager for advice, criticism, and encouragement.

177]

5 
Digitized by the Internet Archive in 2007 with funding from Microsoft Corporation 


\section{CONTENTS}

LIST OF TABLES

\section{CHAPTER I}

The Utility of Income Statistics . . . . . . . . . . . . I5

\section{CHAPTER II}

\section{Ideal Income Statistics}

a. For the development of economic theory . . . . . . . . . 18

b. For the illumination of social problems ............. 19

Scope . . . . . . . . . . . . . . . . . . I9

Method of collection. . . . . . . . . . . . . 19

Accuracy ...................... 22

Presentation ..................... 22

A feasible plan.................... 25

CHAPTER III

SOURCES OF INCOME

a. Definition of income .................. 27

b. Classification of incomes . . . . . . . . . . . . . . 27

c. Incomes from labor . . . . . . . . . . . . . . . . 28

Classification . . . . . . . . . . . . . 28

Salaries . . . . . . . . . . . . . . . . $3^{I}$

d. Incomes from the ownership of property . . . . . . . . . $3^{\text {I }}$

Real estate. . . . . . . . . . . . . . . . . 33

Securities . . . . . . . . . . . . . . . 35

e. Incomes from the right of private property . . . . . . . . 40

Abroad ... . . . . . . . . . . . . . . . . 41

New York . . . . . . . . . . . . . . . 43

f. Summary . . . . . . . . . . . . . . . 43

179] 7 
The Sources of American Income Statistics

a. State labor reports . . . . . . . . . . . . . 46

Annual earnings ............... . . 47

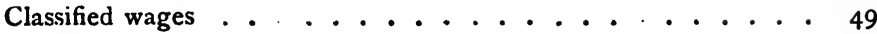

Manufacture ...................... 50

Organized laborers .................... $5^{1}$

b. Census publications

Manufactures, 1900 (Employees and Wages) . . . . . . 53

Mines and quarries ................. 54

Agriculture. . . . . . . . . . . 55

Manufactures, $1905 \ldots \ldots \ldots \ldots 5^{6}$

Special reports . . . . . . . . . . . 57

c. Other federal publications

Department of Agriculture . . . . . . . . . $5^{8}$

Interstate Commerce Commission . . . . . . . . . . 59

Bureau of Labor . . . . . . . . . . . 60

d. Statistics of income from ownership of property . . . . . . 63

e. Summary . . . . . . . . . . . . . . 65

\section{CHAPTER V}

Previous Treatment of American Income Statistics

a. The work of Dr. Spahr

Description ................... 66

Criticism..................... 69

b. Professor Nearing's study of wages

Description .................. $7 \mathbf{I}$

Criticism................ . $7^{6}$

c. Comparisons

Spahr and Nearing . . . . . . . . . . . . . . 79

Spahr and Leroy-Beaulieu . . . . . . . . . . 80

Prussian income-tax returns. . . . . . . . . . 80

British tax returns ................ 83

d. Conclusions ................. 87

\section{CHAPTER VI}

Statistics of the Distribution of Wages

a. The incidence of the burden of family support. . . . . . . 88

b. Limitation of study to earnings of men. . . . . . . . . . 94 
c. The course of wages

PAGE

New York State, manufactures . . . . . . . . . . . 96

United States. . . . . . . . . . . . . . . 98

New Jersey and Massachusetts . . . . . . . . . . I IOI

New York, organized workingmen. ............. 101

Summary ... . . . . . . . . . . . . . 103

d. The distribution of earnings

Manufactures. . . . . . . . . . . . . . 105

Recent trend .................. 108

Comparisons ................... . 110

Heads of industrial families

United States...................... 112

Kansas and Iowa . . . . . . . . . . . . . . . 113

Organized workingmen in New York .. . . . . . . . . 122

Telephone industry . . . . . . . . . . . . . . . 124

Central electric light and power stations . . . . . . . . 125

Incorporated mines and quarries . . . . . . . . . . 126

Male school teachers ................... 120

Clergymen. . . . . . . . . . . . . . . . 129

Farm families ................... 1 130

Civil service .................... . 132

e. Summary of conclusions . . . . . . . . . . . . . . I33

f. Estimate of distribution of annual earnings in some branches of industry. 35

CHAPTER VII

INCOMES FROM PROPERTY

a. Savings banks _................ 140

b. Life insurance....... . . . . . . . . . . . 14 1

c. Productive real estate . . . . . . . . . . . . . 142

d. Factories .. . . . . . . . . . . . . . . 143

e. Tax assessments . . . . . . . . . . . . . . 144

f. Earning power of capital. . . . . . . . . . . . 146

CHAPTER VIII

Summary and Conclusion ................. 151

CHAPTER IX

A Suggestion

a. Farm incomes . . . . . . . . . . . . . . 156

b. Urban incomes. . . . . . . . . . . . . . 158

The rent criterion. . . . . . . . . . . . . . 159

c. Summary . . . . . . . . . . . . . . . 165 
List of books to which reference is made in this essay. . . . . . . . . '167 Additional references . . . . . . . . . . . . . . . 170 


\section{LIST OF TABLES}

I. Classification of Recipients of Incomes from Labor in the United States, 1900 . . . . . . . . . . . . . 30

II. Ratio of Salaried Employees to Wage-Earners in Certain Indus. tries............... $3^{2}$

III. Holdings of Stock in Industrial and Railway Corporations, 190I-19II.

Express Company Holdings of Railway and Express Company Securities, 1907 . . . . . . . . . . . . . foot-note

Holders of Registered U. S. Bonds, 1880 . . . . . . foot-note

IV. Classification of Inheritances in France and England . . . . . 42 Returns of Capital and Labor in Eight Industries. . . foot-note 44

V. Distribution of Estates in New York . . . . . . . . 67

VI. Spahr's Estimate of Distribution of Property in the United State 67

VII. Spahr's Estimate of Distribution of Incomes in the United States. 69

VIII. Classified Wages, Males, Twenty-one Yéars and Over, Massachusetts, 1908 . . . .. . . . . . . . . . 7 I

IX. Cumulative Percentages of Adult Males Receiving Classitied Yearly Earnings (Unimployment Deducted) all Massachusetts Industries, 1908 ... . . . . . . . 72

X. Distribution of Waget inge Various Employments, Railroads of the United States, 1909 l. . . . . . . . . . . . . . . . 74

XI. Cumulative Percentâges of Males Receiving Certain Classified Weekly Earnings, Compiled from Certain Reports, 1908-1910. 75 Rents and Incomes in Parid. . . . . . . . . . . foot.note 81

XII. Income Taxes-Prussia, $190_{5}$. . . . . . . . . . . . 82

XIII. Income Tax-United Kingdom, 1909-10 . . . . . . . . . 84 Salaried Employees-Men and Lads . . . . . . . . foot-note 85

XIV. Rental Values of Houses in England and Scotland . . . . . 86

XV. Total Family Incomes and Earnings of Fathers, 391 New York City Families, 1907 . . . . . . . . . . . . . 90

XVI. Family Incomes and Earnings of Fathers, New Jersey, 1888 . 91

XVII. Variation of Probability that Husband's Earnings will be Supplemented, with Respect to High Limit of Husband's Earnings. 93

XVIII. Monthly Wages of Men in Manufactures, New York State, 1865. 97 
XIX. Weekly Wages of Men in Manufactures, Sixteen Years and Over, New York State, 1904 . . . . . . . . . . . 97

XX. Wages in Manufactures in the United States, Classified Weekly Earnings of Males Sixteen Years and Over . . . . . .

Compensation of Employees of the Railways of the United States, Showing Increase of Daily Wages, 1900 to 1910 . . foot-note 103 XXI. Classified:Weekly Wages of Males, Sixteen Years or Over, Engaged in Manufacture in the United States in 1904. . . . . 105

XXII. Comparison of the Classified Earnings of Heads of Families with Classsified Wage' Rates of Males Sixteen Years and Over, all Faétory Enployees ........... 107

XXIII. Wages of Males in Four States, Engaged in Manufacture . . . Io9

XXIV. Clasşfied A nnual Earnings of Heads of Families, 1901 . . . I I I

XXV. Per en of of of ads of Families in Each Group, of Classified Earnitigs, in Occupations Embracing 100 or more Persons [çondensed]

XXVI. Classified Incontestloe the Years 1903, 1904, 1906, and 1907, Family Obligatjons Wage-Earners in Kansas

XXVII. Classified Earnings of Certain Wage-Earners in Iowa, 1905,

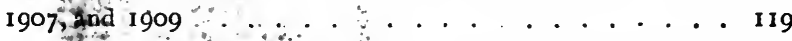

VIII. Summary Table of Classified Incomes of Certain Kansas WageEarners and "Classified Earhings of Certain Iowa Wage-

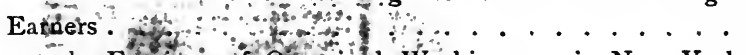

XXIX. Quartery Earmings of Ofganized Workingmen in New York State

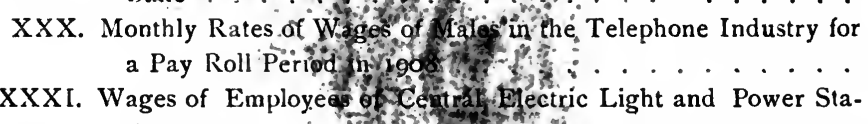

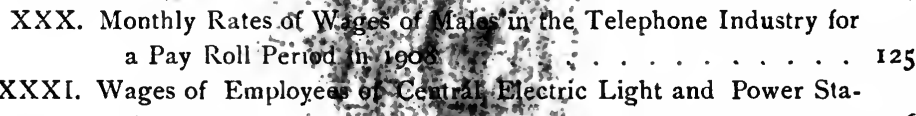

tions, I902 . . . . . . . 126

XXXII. Daily Wages of the Emplogees of Incorporated Companies, Mines and Quarries, in $190^{\circ}$ * $^{\circ}$ :

XXXIII. Salaries of Male Teachers in Public Schools in Cities of 8000 or

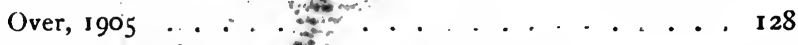

XXXIV. Incomes of Methodist Epistopal Ministers in 1910 . . . I 130

XXXV. Farms, Classified by the Value of Products not Fed to Live Stock, I899 . . . . . . . . . . . . I3I

XXXVI. Distribution of Compensation of Employees in Executive Civil Service, 1907 . . . . . . . . . I32

XXXVII. Estimate of the Distribution of Incomes Primarily from Labor. I 37

XXXVIII. Distribution of Assessments in Newark, Camden, Jersey City, and Patterson, in 1905. . . . . . . . . 144

XXXIX. Earnings of Invested Capital .......... 148 
XI. Relation of Rent to

XL. Relation of Rent to Earnings, St. Louis, 1890 . . . . . . . 159

XLI. Distribution of Rents among 254 St. Louis Families, 1890 . . . 160

XLII. Distribution of Incomes among 254 St. Louis Families as Computed from Rentals by First Method, and as Enumerated . . 161

XLIII. Distribution of Incomes among 254 St Lnwis Families as Com-

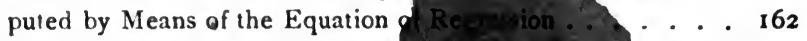

XLIV. Computation of Distribution of Coevenct trom Distribution of Rents, 254 St. Louis Families.

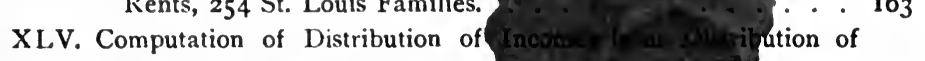
Rents, 391 New York Families . . 164

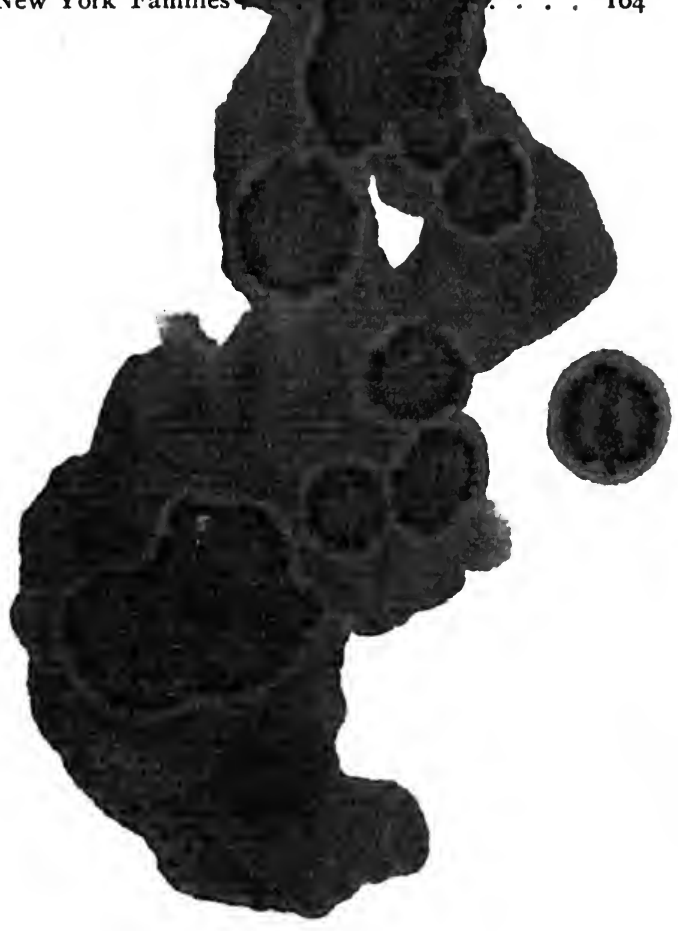




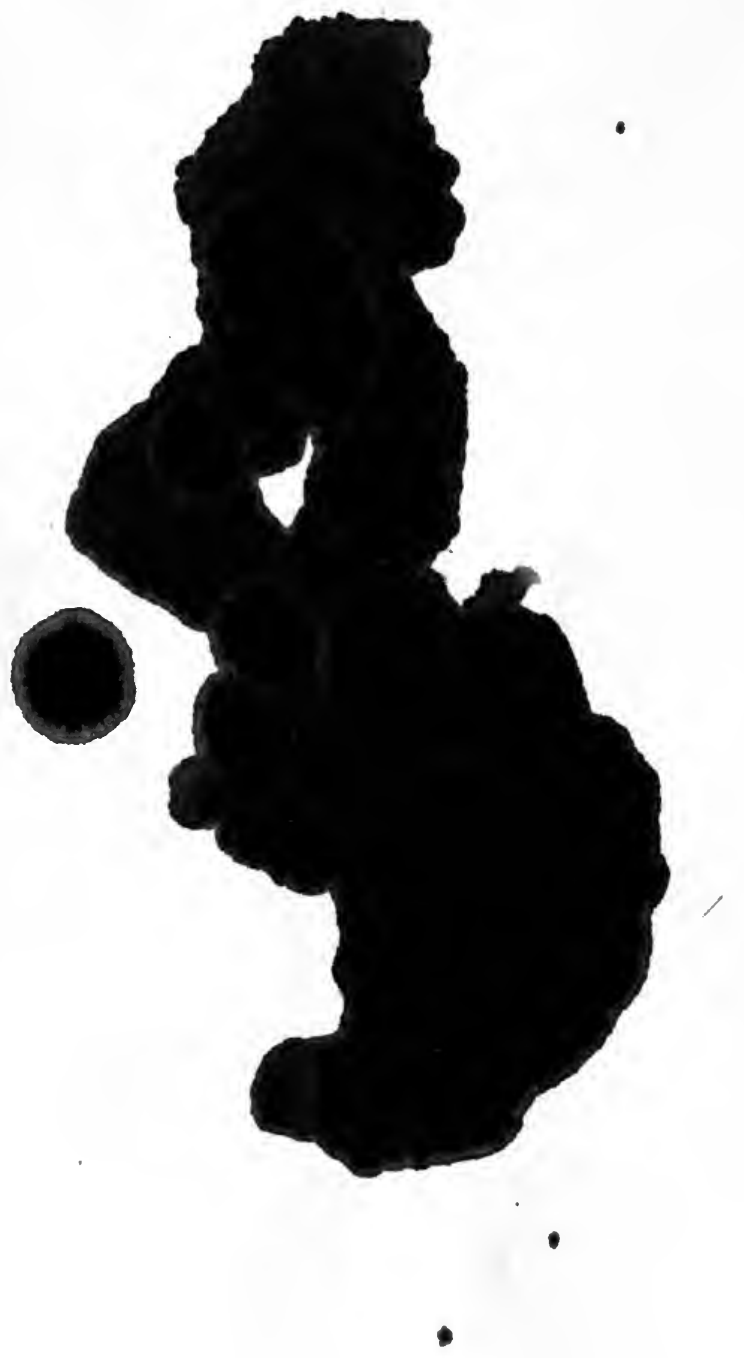




\section{CHAPTER I}

\section{The Utility of Income Statistics}

IN the evolution of certain industries, "costing" and the standardization of efficiency are potent factors. As, in the proper conduct of a large business, it is necessary to have within easy reach all the facts which would bear upon the solution of any great problem that may arise, so the possibility of perfect legislation is doubtful unless the law-makers possess an intimate knowledge of the conditions with which they are attempting to cope. This principle is recognized practically in the habit of appointing commissions to investigate important state and national questions. There is a considerable group of problems which must be considered, both by these legislative committees and by individuals, largely with reference to the distribution of incomes. For instance, the present organization of industry is accompanied by certain demands for social insurance-old-age pensions, workmen's compensation, sick benefits, and unemployment relief. Only by one who is well acquainted with the resources of the family groups in the classes involved can the desirability, or the necessity, of adopting any one of these proposals, or any combination of them, be discussed intelligently. The advisability of old-age pensions, for example, depends largely upon the answers of two questions: (I) Do a large majority of American workingmen have the opportunity, supposing they are no more thriftless than lack of education and their environment inevitably make them, to provide for their own years of decline? and (2) Can the I87] 
large majority of Americans, if necessary, support aged parents without real injury to themselves and their families, and how often does the necessity arise? These two questions cannot be answered without statistics of the distribution of incomes. But even if the legislators have decided to introduce a system of old-age pensions, they must determine the method of financing the new institutions; and here ability to make compulsory contributions to the fund, or to pay taxes, should be considered in the light of incomes.

Again, if the proposed Sixteenth Amendment is passed, and if an income tax is to be imposed, would it not be wise in fixing rates to consider the probable yield? Can this be done without knowledge of the base of the tax? And if this base is personal income, as it was in the impost of Civil War times, statistics of income are needed. Similar considerations should be recognized in imposing other taxes.

Minimum wage laws and child-labor regulations can hardly be classed either with social insurance in the narrower sense or with the income tax, and yet they are measures of such deep economic significance that they demand of the legislature scientific consideration as well as political attention-a deep knowledge of the actual state of affairs and of the probable effects of new enactments. Finally, it is hardly a matter of doubt that the majority of influential Americans are in ignorance of the actual amount and diffusion of wellbeing in their own country. Conclusive statistics are necessary to show them the facts, really to acquaint the citizens with one another. The attitude of many people upon the great social questions of the day is to a large extent influenced by their conception of the present distribution of wellbeing, and of the tendency toward improvement or the reverse.

So, in the framing of social legislation, in the assessing of certain kinds of taxes, and in influencing individual and 
public opinion, statistics of the distribution of incomes have a real utility.

It is the purpose of this essay to show that at present the United States lacks the income statistics that might have this utility, to point out what the figures, which are available, seem to indicate, and to suggest a plan by which more satisfactory statistics of incomes may be secured. 


\section{CHAPTER II}

\section{Ideal Income Statistics}

THE exact character of the ideal compilation of income statistics depends on the purpose in view. If, for example, following the lead of Professor Henry L. Moore, it is determined to submit to empirical test the current wage theories, the minimum necessary information concerning each individual would doubtless include, besides his actual earnings: (I) his race, sex, age, and experience; (2) the industry and exact occupation in which he is employed, the amount of skill involved being expressed, if possible, numerically; (3) the degree of organization of labor in the occupation, the membership or non-membership of the individual in the union, and the character of the employing establishment; (4) the size of the plant in which he is employed, the amount of capital invested, and the value of machinery and of net output, per laborer, in the whole business and in the department ; (5) his geographical location, and the regularity of employment in his trade. These data should be supplemented by other studies of the standards and costs of living, and of the purchasing power of money; the presentation would involve an indefinite number of two and three dimension tables. The first comprehensive attempt to furnish such a study for the United States has been made by the Bureau of Labor in its elaborate Report on Condition of Woman and Child Wage-Earners in the United States, a work which contains much that may be turned to account I8 
by the theorist. For the objects mentioned in the preceding chapter, however, no such elaboration is necessary; in truth, it might conceal the vital concerns under a mass of detail. The following sketch will, therefore, be confined to a description of the statistics necessary for an intelligent grasp of those great social questions which are now rising to recognized importance.

To be really complete, these income statistics must include returns from every gainfully-employed person, whether a high-salaried corporation official, or a child in the tenement. In addition, pensioners and individuals living upon the earnings of property should be tabulated, and the final summary should be a classification of the entire number of income-receiving individuals and families by the size of their total incomes. Doubtless any attempt to investigate the earnings of "business" men would to-day be deemed "inquisitorial" and be stoutly resisted; but the impossibility of such a study detracts nothing from its desirability. The wage earners, however, are those whose interests are most in need of protection in the crises of life; so, if it is impossible to secure returns from the men who are eminently qualified to take care of themselves, the social reformer may find a sufficient working basis in data covering the other classes in industrial society.

In the collection of statistics of income, recourse may be had to three sources; a canvass may seek returns from individuals, or the data may be gathered through the employers, or through the officials of labor organizations. The basis of the figures of earnings and of unemployment compiled by the New York State Department of Labor is the report of the secretary of the union; but even with complete returns from all the "Locals" in the country, a very small proportion of the gainfully employed would be represented, since the unskilled, unorganized. numerous but low paid, 
workers would be omitted. ${ }^{1}$ It would, therefore, be unwise to build largely upon statistics drawn merely from the organizations of laborers, even if complete confidence could be placed in the accuracy and extent of the knowledge of their officials. Of the other two sources of information, each has its peculiar merits and defects.

An excellent statement of the case in favor of securing data from employers is the following by Professor Davis R. Dewey:

In the collection of data it was decided to rely upon the payrolls of employers; only in this way is it possible to secure returns from all the constituent elements in a given establishment, for it is manifestly impracticable to visit each separate employee to obtain a personal return; and, moreover, it is clear that the pay-roll of the employer states in the most precise form available the actual rate of pay of each employee. This method removes all opportunity for either exaggeration or under-estimation, and also the possibility of substituting a customary wage for the actual one. ${ }^{2}$

This is true; yet in considering the value of the method it must be recognized that the employer may not be willing to furnish his pay rolls, that the agent may be careless as some census takers certainly have been, or that the records may be confused. To ask the employer to assume the expense and trouble of filling out the blanks himself, seems to invite hasty, slip-shod work; nevertheless, where this is done annually, as in Massachusetts and New Jersey, there may be established a high standard of accuracy. The one permanent fault of the pay roll as a source of income statis-

1 There were in 1910 about 2,625,000 members of American trade unions, United States and Canada, as compared with about 35,000,000 gainfully employed persons in the United States alone. Bulletin, New York Department of Labor, no. 48, Sept. I9I I, p. $4 \mathrm{I} 8$.

2 Twelfth Census, Report on Employees and Wages, p. xvi. 
tics is the difficulty of deriving annual earnings from weekly or fortnightly records ; especially is this true of factory people, who have a habit, in some towns, of shifting frequently from one mill to another, apparently for the sake of variety. Combine this difficulty with the complications which would follow upon the attempt to trace one man through twentysix or fifty-two separate pay rolls, a man who may have lost some time; then multiply by the number of employees in a large establishment, and the stupendousness of the task of arriving at annual earnings from the records of employers will be clear. Even supposing a satisfactory knowledge of annual earnings, the matter of family incomes is still untouched. The way out, however, is not far to seek; a large number of names may be chosen at random from the pay rolls, and the individuals visited. These individuals may be asked for details as to annual earnings, unemployment, and family incomes. This method has been used by the Bureau of Labor in recent investigations with gratifying results. ${ }^{1}$

An attempt to obtain income statistics by a canvass of individual families would have the advantage of going directly to those who should be able to say how much they have earned as individuals during the year, and what the combined family income, including that from property has been. On the other hand, there seem to be many households that would find it impossible to impart even this information, and, barring this complication, if a random selection were made, some industries and occupations might be inadequately represented. In view of all these considerations, the correct conclusion seems to be that the best source for income statistics is the pay roll of the employer, supplemented

'See for example the report on Women in Department Stores, vol. v of the Report on Condition of Woman and Child Wage-Earners in the United States, p. 12 et seq. 
by individual inquiries among his workers. If it could be made successfuly, however, there is no doubt that a houseto-house canvass would give exactly the data needed for social purpoiies.

It is by no means imperative that such investigations cover every gainfully-employed individual in the United States, or every family.

In any given locality there is a strong tendency toward uniformity of wages in the same occupation; if, therefore, the occupations are carefully designated, the number of returns for a given occupation need not necessarily be inclusive of all employees engaged in the same kind of work. The more precisely the occupation is described, with regard to sex, age, and gradations of skill, the fewer are the numbers needed. ${ }^{1}$

In determining the size of the sample, each occupation would probably need separate consideration. Of course, the larger the sample, the greater is the probability that the results are truly representative; but it must be borne in mind that for practical purposes it makes very little difference whether the percentage of adult male factory employees earning under \$12 per week in 1904 was 62.1 or 62.7 ; the point that is important is that it was about sixty, and not fifty or seventy. If, on the other hand, the inquiry be directed to ascertaining whether wages are rising or falling, then the fact that from 1890 to 1900 the average rate of weekly pay of male factory hands as shown by the Dewey Report, fell from $\$ \mathrm{II} .57$ to $\$ \mathrm{II} .5^{2}$ is extremely significant. So if absolute accuracy may not be necessary for the consideration of certain great social problems, whenever a question of tendency is involved, it is highly desirable.

Important as are these matters of scope and source in determining the value of income statistics, the manner of

${ }^{1}$ Twelfth Census, Report on Employees, and Wages, p. xvi, par. 2. 
presentation is just as vital to their utility. Arithmetic averages, so easily understood, are probably necessary for comparisons in time and in space; and the application of methods of correlation may disclose new and important uses for this summary expression. The mode, too, if only approximated by inspection, is a more concrete concept than the mean, and thus may show what a normal man might expect to earn in a given occupation at a certain place. But both the average and the mode lose much of their significance if applied to an entire state, or even to one branch of industry. These summary expressions must, therefore, be supplemented by classifications. Weekly wages should be presented in fifty-cent or dollar groups, annual incomes or earnings, in one-hundred-dollar groups, at least until $\$ \mathrm{r}, 500$ is reached. Only thus can distribution be shown.

In the presentation of income statistics, the time unit causes no small difficulty. The smallest period that can be considered economically complete is the year, for only the annual unit is unaffected by the succession of seasons which is so vitally connected with agriculture, lumbering, fishing, canning, rice cleaning and polishing, ice manufacture, millinery, and a host of other industries. Moreover, salaries are expressed in terms of the year. By the use of no other than the twelve-month unit can the factor of unemployment be adequately taken into account. As has been pointed out. however, incompetence, carelessness, and unwillingness of individuals in answering questions, coupled with the difficulty of following one person through many pay rolls are great obstacles to the practical application of the annual unit. It must be admitted, on the other hand, that in Igor, the Bureau of Labor actually did procure apparently reliable returns of the annual incomes of over twenty-five thousand families. $^{1}$

${ }^{1}$ See the Eighteenth Annual Report of the Commissioner of Labor, Wages and the Cost of Living. 
The natural pay time-unit seems to be the week, and it is the weekly rate, or the actual weekly wage which is most easily procured from the pay rolls. If the rate of pay is presented, as in the Dewey Report, the reader is not told what actual earnings are, but if the earnings are published the returns cannot be exactly interpreted without a knowledge of how many individuals have been shifted from one group to another by the lost days or over-time which may have been peculiar to their particular establishment in that week. From this dilemma the Census of Manufactures of I905 seeks escape by recording actual earnings for the "busy week" or week of largest employment in each establishment. Even this expedient is open to some objection, as in the busy week, there may have been employed an unusually large proportion of comparatively inexperienced and unskilled hands; this would tend to swell the lower wage groups; but on the other hand, there would probably be an unusual amount of over-time in this period. The selection of a "normal" week is probably one which secures the closest approximation to true representation of the distribution of earnings. This a priori discussion cannot settle the point; it may make little practical difference whether the busy, the normal, or a certain week arbitrarily fixed by the calendar is selected. Only experiment will afford the answer; but this much is certain and important-whether rates or earnings be tabulated, weekly pay is a very uncertain guide to annual incomes from labor. ${ }^{1}$

Another point at which the ideal and the possible conflict is in the choice of the unit of labor. It seems vital to know the facts about family incomes, but for this purpose

${ }^{1}$ Hourly and daily rates or earnings, provided they are accompanied by the hours of labor per day and per week, will usually lead to substantially the same results and are of course subject to the same limitations as weekly figures. 
the earnings of individuals are of little value. It is also desirable to know how many mature men are able, without the aid of wives and children, decently to support their families. For this purpose weekly figures fail, and the Census division between men and boys at the sixteenth birthday is futile.

In view of all these difficulties the claim of any feasible statistics of income to be called "ideal " must be advanced with modesty. In the first place, ideal income statistics would be separately tabulated for the urban and rural portions of each state or group of states, and would be supplemented by corresponding data on the costs and standards of living, or on the purchasing power of money. The families of each locality would be grouped by total annual income in classes of one hundred dollars, at least until the fifteen-hundred-dollar mark was reached and preferably as far as two thousand dollars; from that point five-hundred-dollar groups would suffice. Each income group would be again subdivided according to sources: is the revenue derived from the ownership of property, from the earnings of the family's head, ${ }^{1}$ from the earnings of the head increased by wages of other members of the household, from the ownership of property combined with the earnings of the head, or from property and earnings of the head and other family members? Another classification would divide men of at least twenty-one years according to earnings, occupation, residence, and race. The data would be collected by expert special agents, in a house-to-house visitation, all doubtful returns being ruthlessly discarded.

The funds being unavailable for so elaborate a study, the weekly wage rates of men of voting age might be drawn from the pay rolls of as many employers as possible. Names

${ }^{1}$ By head is meant here the earner of the largest wages. 
of men, selected in considerable numbers from each occupation, would be made the basis of a canvass for further facts concerning the amount and sources of the total family income and the amount of unemployment during the year. A special investigation would have to be made into the incomes of farm families, of fatherless households, and of as many employers and business men as would submit to the "inquisition". The results would establish with more or less accuracy the relations between wage rates and annual earnings for the different occupations, and between wage rates and family incomes, and from these relations the distribution of incomes among families might be approximated. In order to make this estimate possible, however, the distribution of family incomes among the men of each wage group would have to be shown.

Either one of these studies would fall short of the ideal: the first because it would be impossible to obtain the necessary data from a large group of fairly well-to-do and prosperous families, the second because it would depend so largely upon estimate. Yet either method would probably afford a sufficient foundation for the discussion of the problems outlined in the first chapter. 


\section{CHAPTER III}

\section{Sources of Incomes}

As is the case with many economic terms, the best meaning of "income" is a matter of dispute. The income of an individual may be defined psychologically as a sum of enjoyments available in a unit of time. Impossible it may be at present to measure "pleasures and pains"; yet the fact that increases in the rates of wages among certain groups of the population are regularly followed by augmented voluntary idleness, makes the "enjoyment" idea of real importance to the economist. Even if the scope of the word be limited to material things, there is no final agreement. Suppose, for example, that in the course of the year I9I2 Mr. A buys on various days fifty city lots at an aggregate cost of \$75,0oo, and subsequently sells them for a total price of $\$ 100,-$ ooo. He may have begun the year with $\$ 30,000$ and ended it with $\$ 55,000$, yet to the minds of some scientists his income was $\$ 100,000$, of which he spent a large proportion. Others would hold that Mr. A's income was $\$ 25,000$, or $\$ 25,000$ minus the cost of carrying on the business. In view of these differences of definition, it is necessary to state that, for the purposes of this essay, the income of an individual is the aggregate of economic goods which in the course of a unit of time become available to him for final consumption without entailing impairment of his capital. Unless otherwise stated, the time unit is the year, and the income is expressed in terms of money. So defined, personal incomes are derived from three sources: from LABOR, 
from the OW NERSHIP OF PROPERTY, and from the RIGHTS OF PRIVATE PROPERTY.

"Labor is a wealth-creating effort." 1 Any human exertion directed primarily toward the creation of utility is labor. Although the work of a child at school may create "productive power", the immediate end not being production, it is not economic labor. "The remuneration of labor," 2 " the earnings assigned to men for their work," 3 in other words, the recompense of human exertion in the production of utility is wages. Thus in the economic sense wages includes more than is popularly understood by the term, includes all material incomes which reward labor. Theoretically every one of the thirty million Americans engaged in gainful occupations either actually receives or should impute to himself wages. The salary of the president of the United States Steel Corporation, the profit of the underwriter, and the pay of the laborer fall in the same category. These examples, however, illustrate the three varieties of wages.

Perhaps it would be better to say that there are two classes of wages, one of which may be subdivided. In the first place, the amount of remuneration may be determined in advance by definite agreement. Such a stipend is a salary if the contract is for a year or more, wages (in the popular sense) if the time unit is less than twelve months. ${ }^{4}$ Although, perhaps, not strictly included by the definition, what are generally known as piece payments are rightly classed with wages proper for two reasons: first, the piece rate is usually determined in the beginning by what a normal oper-

' J. B. Clark, Essentials of Economic Theory, p. 9.

- Seligman, Principles of Economics, p. 4II.

- Seager, Introduction to Economics, p. 222.

- Abstract of the Twelfth Census, p. 300, note 2. 
ative produces in a given period, and is frequently reduced if this standard is much exceeded: ${ }^{1}$ second, the tasks of the piece worker, and his social position correspond very closely to those of the time worker. The other class of rewards of labor includes those forms of compensation which depend in a peculiar degree upon the skill, energy, and good fortune of the recipient. Under this head would fall, for example, the commissions of salesmen and of brokers, the "profits" of the farmer and shop-keeper (except interest on capital), the incomes of physicians and lawyers, and a large part of the speculator's gain. Although there seems to be no recognized name for this group of indeterminate remunerations, for convenience, and without essential inaccuracy, it may be styled " contingent earnings". The income of a particular individual may vary but little from year to year and still be in a proper sense "contingent". This distinction is by no means fanciful, for, in addition to the economic significance, there are corresponding lines of social cleavage. In society the salaried man seems to occupy a higher position than the wage earner, regardless of the comparative size of their incomes; in the four hundreds, are the families enjoying contingent earnings. Doubtless this social gradation is partly due to the distribution of property: the wage-worker is seldom a large owner, the salaried person may not possess property but often does, and a prime requisite for the enjoyment of a contingent income is frequently the control of some capital.

That one man may procure labor incomes of all three classes should require no explanation. A professor, for instance, may be paid a salary for teaching, he may be given a weekly wage for summer work in a government bureau. and may in addition be blessed with large checks for scien-

1 Adams and Sumner, Labor Problems, p. 264; Twelfth Census, Employees and Wages, p. xix. 
tific articles, or fees as a consulting expert. Thus one person may receive a salary, wages, and a contingent income.

Recognizing, then, this demarkation of the rewards of labor into wages, salaries, and contingent earnings, the question of the relative importance of these groups arises. A1though no attempt has ever been made in the United States to gather statistics upon the basis of such a classification, an approximation may be obtained from the data in the Census of Occupations and in the Census of Manufactures. The latter distinguishes between "firm members ", "salaried employees", and " wage-earners". In the light of this information, and of a general knowledge of the modes of remuneration in the various branches of industry it is possible to form a rough table.

TABLE I

CLASSIFICATION OF RECIPIENTS OF INCOMES FROM LABOR IN THE UNITHD SIATES, I,$O O$

\begin{tabular}{|c|c|c|c|}
\hline I. & II. & III. & IV. \\
\hline Division of industry. & Wages. & Salaries. & $\begin{array}{l}\text { Contingent } \\
\text { earnings. }\end{array}$ \\
\hline $\begin{array}{l}\text { Agricultural pursuits . } \\
\text { Professional service } \\
\text { Domestic and personal service } \\
\text { Trade and transportation } \\
\text { Manufacturing }{ }^{1} \text { and mechanical }\end{array}$ & $\begin{array}{r}4,863,000 \\
6,000 \\
5,154,000 \\
2,317,000 \\
6,001,000\end{array}$ & $\begin{array}{r}18,000 \\
819,000 \\
131,000 \\
1,079,000 \\
403,000\end{array}$ & $\begin{array}{r}5,557,000 \\
440,000 \\
409,000 \\
1,382,000 \\
709,000\end{array}$ \\
\hline 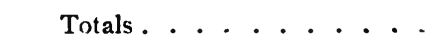 & $18,341,000$ & $2,45^{\circ}, 000$ & $8,497,000$ \\
\hline
\end{tabular}

From this it would appear that, of the twenty-nine million

1 Proprietors and firm members, 708,623; salaried officials, clerks, etc., 397,092; wage-earners (average number), 5,314,539. Abstract of the Truelfth Census, p. 300. 
persons gainfully employed in I900, about six-tenths were wage-earners, nearly one-tenth were on salaries, and approximately three-tenths enjoyed contingent incomes. ${ }^{1}$

In this connection it is interesting to note that the salary seems to be gaining in favor over the wage as a form of remuneration. In I899, the factories employed 5,079,225 persons, of whom 7.I 5 per cent were on salaries; in 1904, $5,990,072,8.68$ per cent being on salaries; in $1909,7,405,-$ 3r3, with 10.67 per cent salaried. Perhaps the magnitude of this change is made more apparent if it is stated thus: in 1899 , the factories employed one salaried person to every I2.9 wage earners; in I904, one to every 10.5 ; in 1909, one to every $8.4 .^{2}$ Table II shows that so far as the facts are revealed by published clata this movement toward the salary as a form of remuneration is general. Whatever may be the significance of this tendency, one inference can be drawn with some degree of assurance; an increase in the proportion of workers who receive salaries means an increase of the proportion of the employed class who, being able to count on a definite annual income, do not need to dread recurring periods of unemployment.

The second source of income is the ownership of property. The yield of lands and houses, the return from capital-whether invested in mortgages, bonds, stocks, partnerships, or individual businesses-royalties, and other less important forms of revenue, in fact all that the Economist calls rent, interest, and profits, are included in this class. Profits belong to the owner of a business, whether or not he owns the capital or manages the concern. In its pure form,

${ }^{1}$ It is interesting to note the rough agreement between these results and the estimate of Professor Seager-employing class, 9,830,000; employed class, 19,100,000.

2 Thirteenth Census Bulletin Manufactures: United States, p. 3. Table II of this essay also. 


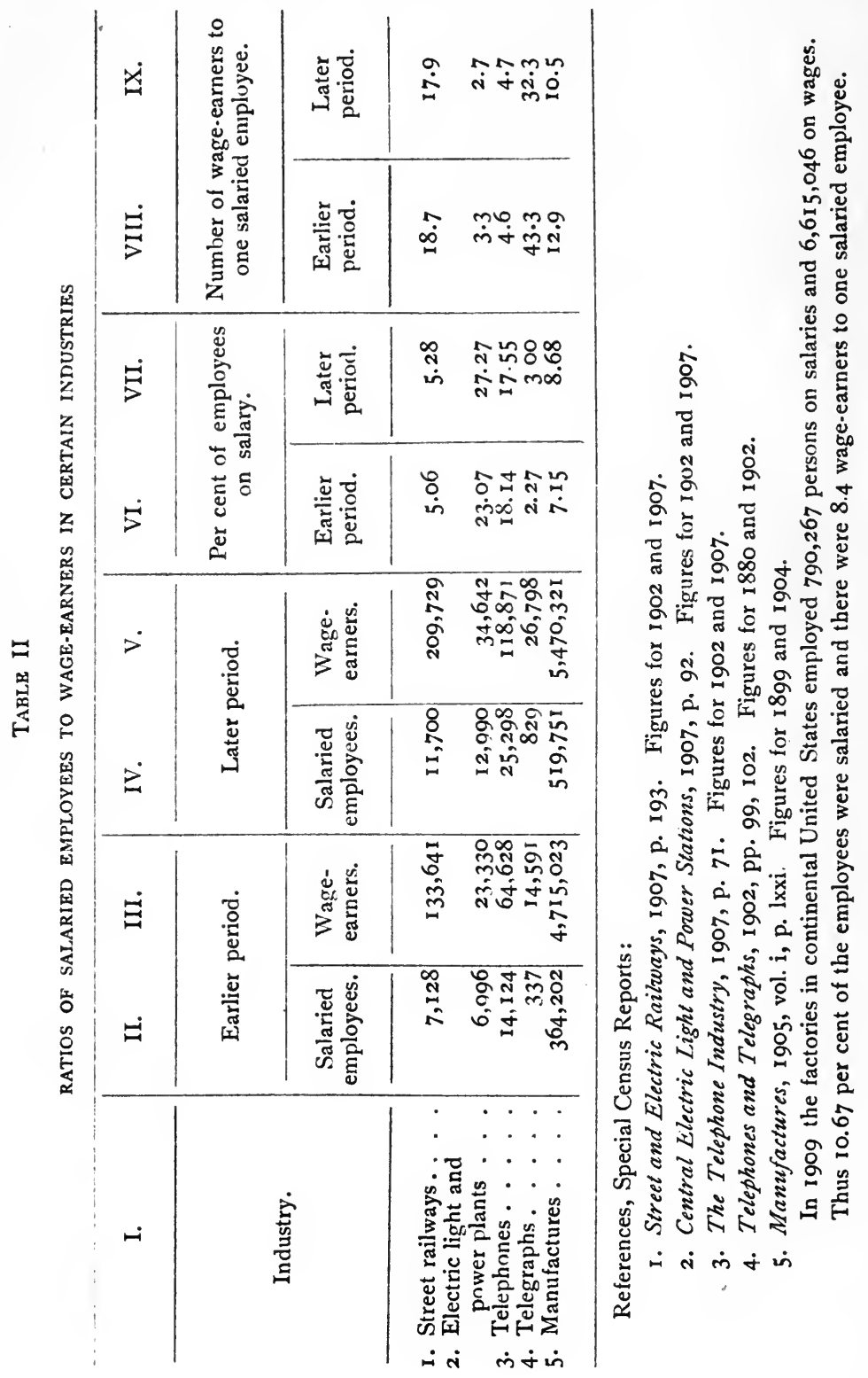


income from property ownership accrues, for example, to one whose fortune consists of stocks and long-term bonds, one who receives dividends and interest without the necessity of reinvesting; or to a person who leaves the administration of his wealth entirely in the hands of an agent, trustee, or attorney. If, however, the individual speculates on the exchange, rents his own houses, purchases short-time mortgages, tills his farm, or conducts his store, then his income is derived from two sources, labor and the ownership of property. However clever he may be, without the control of property, the speculator can not carry on his business, and so, although his skill enormously increases his earnings, they are due in part to capital, are not pure economic wages. There seems to be a considerable number of men, who, with a small sum of, say, ten thousand dollars, by devoting their entire time to the stock market, extract annual incomes of an approximately equal amount. By way of contrast, it is not an extremely infrequent phenomenon for the proprietor of a business to continue year after year with a net income less than his capital would earn if otherwise safely invested. His wages are either negative, or else they are entirely psychological and consist of the pleasure of being an entrepreneur; considering the situation from another viewpoint, his wages are ample, but his investment bears scant interest. Thus it is apparent how difficult may be the attempt to distinguish between income from the ownership of property and income from labor: in practice they are frequently inseparable.

How many American citizens own property is a question that defies statistical answer. It is, however, possible to present some facts in regard to holdings of real estate and of corporation securities. The Census of 1900 shows that, of the $10,488,8$ I 4 families not on farms, $2,338,533$, or 23.4 per cent, owned their own homes clear of encumbrance; 
I, IOI,8O2, or I2.9 per cent, lived in mortgaged houses to which they held title; and the remaining 6,35I,836 hired their dwellings. ${ }^{1}$ That a large proportion of the non-rural families do not possess real estate, is, therefore, perfectly clear, but to the actual number of owners of these six million hired tenements, no clue is evident. Again, in 1900, there were $5,739,657$ farms, of which 3,654 , I 58 were occupied by owners and part owners, over a million being mortgaged. Hired managers cultivated 59,2 I 3 farms, and the other 2,026,286 were rented. ${ }^{2}$ The ownership of 95.5 per cent of these rented farms could be traced, and it was found that their titles were held by $1,257,716$ individuals. ${ }^{3}$ Since seventy-five per cent of the rented farms were in the county of the owners' residence, it is highly probable that many of these landlords lived upon other farms which they owned. It may therefore be concluded that there were not more than five million nor less than thirty-six hundred thousand title holders of the 5,739,657 American farms. ${ }^{4}$ Uncertain as these figures are, they become still more vague when the mortgage complication is introduced. Thus, the number

1 Abstract of the Twelfth Census, p. 28.

2 Twelfth Census of the United States, vol. v, Agriculture, pt. i, p. lxvi. The Advance Statement of General Agricultural Data, issued by Director Durand of the Census Bureau in September, I9II, shows that of the 6,340,357 farms in 1910, 3,933,705 were worked by the owners, I,3II,364 being mortgaged; 2,349,254 were held by tenants, and 57,398 were in charge of managers. Thus the per cent of farms held by tenants had increased from 35.3 in 1900 to 37.1 in 1910 . During the same period it seems that the per cent of mortgaged farms among those inhabited by owners increased from about 30.4 to 33.3 .

${ }^{3}$ Twelfth Census of the United States, vol. v, Agriculture, pt. i, p. Ixxxvii.

4 For strict accuracy this number should be increased by about 45I,515 , the number of part owners on farms, making the maximum 5,450,ooo owners. 
of owners of real estate can not even be guessed. And were this number known, a new problem would arise in determining how many put their land to productive uses, for there are persons who are "land poor", others own parks, or run expensive dilletanti farms, and there are always vacant houses. Even to approximate the number of persons deriving incomes from the ownership of real propperty, is, therefore, impossible.

If the distribution of ownership of real estate is hidden, what of industrial capital? The Wall Street Journal of $3^{1}$ August, I9I r, presented a list of some 242 railroad and industrial corporations, giving for each the par value of the outstanding capital stock, the number of shares, the number of shareholders, and the average number of shares per stockowner, at the closing of the books nearest to July $\mathrm{I}$, I90I, I906, and I9II. These figures are summarized as follows :

TABLE III

HOLDINGS OF STOCK IN INDUSTRIAL AND RAILWAY CORPORATIONS, IgOI-IgII

\begin{tabular}{|c|c|c|c|}
\hline I. & II. & III. & IV. \\
\hline & I9II. & I 906. & I901. \\
\hline $\begin{array}{l}\text { Capitalization (stock) } \ldots \ldots \ldots \\
\text { Shares } \ldots \ldots \ldots \ldots \ldots \ldots \ldots \\
\text { Shareholders } \ldots \ldots \ldots \ldots \ldots \\
\text { Average shares per holder..... } \\
\text { Average par value of stock per } \\
\text { holder } \ldots \ldots \ldots \ldots \ldots \ldots \ldots\end{array}$ & $\begin{array}{r}\$ 8,997.347,426 \\
110,426,197 \\
872,392 \\
126.5 \\
\\
\$ 10,313\end{array}$ & $\left|\begin{array}{r}\$ 7,323,147,307 \\
86,634,251 \\
394,842 \\
219.4 \\
\\
\$ 18,547\end{array}\right|$ & $\begin{array}{r}\$ 5,559,275,316 \\
60,254.988 \\
226,480 \\
266.1 \\
\$ 24,546\end{array}$ \\
\hline
\end{tabular}

Among other interesting deductions, the Wall Street Journal maintains the following:

I. Only a little more than $\$ 10,000$ par value is in the hands 
of each holder, or in the terms of shares of stock which aggregated about II0,000,000, less than I30 shares to each average holder.

2. Broadly speaking, despite the growing capitalization, stocks are receiving larger distribution year by year. The unit shareholder owns a smaller amount to-day than five years ago, and a still smaller one as compared with I90I. Corporations, in other words, are owned not by the great financiers, but by the Ioo-share men, the owners of $\$ 10,000$ worth of stock each.

3. What an army of shareholders is summed up in 870,000 holders from 242 reporting companies!

It must be recognized that, in preparing this table, the Wall Street Journal has rendered a valuable service. There is no apparent ground for doubting the soundness of many of the writer's conclusions, but some of his assertions are so worded as to make upon the casual reader an impression which the figures certainly do not warrant. Among these doubtful propositions are the three quoted.

In the first place, the sum of the numbers of stockholders in the several corporations is not necessarily the number of individuals who own the stock. For example, the shares of the United States Steel Corporation were owned by one hundred twenty thousand persons, and those of the Pennsylvania Railroad by sixty-nine thousand. Is it possible that there were no individuals who were investors in both of these companies? One does not have to seek very far in some parts of New York City in order to find men who are interested in several corporations! It is, indeed, mathematically possible that the one hundred twenty thousand owners of the "Steel Trust" were also the owners of the entire two hundred forty-two concerns on the list. ${ }^{1}$

${ }^{1}$ The writer for the Wall Street Journal ignores the great importance of inter-corporate holdings. The Special Report of the Census Bureau 
The true number of individuals actually holding the stock of these companies could be discovered only by eliminating duplications through a comparison of the names on the registry books. As an illustration of the possible import of this criticism, it may be illuminating to cite the case of the Standard Oil Company. In July, I9 I , according to the Wall Street Journal, this company had a capital stock of $\$ 98,388,300$, divided among 6, IO I persons. Since that time, the corporation has been dissolved into thirty-three companies, each shareholder receiving a proportionate amount of stock in each concern. Thus, supposing no sales to have taken place, if the article were being written to-day,

on the Express Companies, 1907 (pp. 19, 20), shows the following holdings by express companies:

EXPRESS COMPANY HOLDINGS OF RAILWAY AND EXPRESS COMPANY SECURITIES, I907

\begin{tabular}{|c|c|c|c|}
\hline I. & II. & III. & IV. \\
\hline Express company. & Railway stock. & Railway bunds. & Express stock. \\
\hline 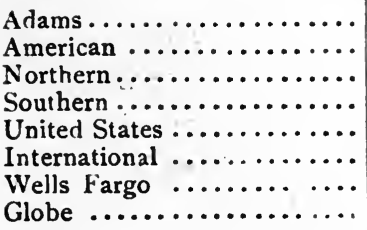 & $\begin{array}{r}\$ 13,865,650 \\
8,002,800 \\
100,000 \\
55,000 \\
195,500 \\
\ldots \ldots \ldots \\
\ldots \ldots \ldots \ldots\end{array}$ & $\begin{array}{r}\$ 902,000 \\
6,730,000 \\
\cdots \ldots \ldots \ldots \\
215,000 \\
3,454,000 \\
\cdots \cdots \cdots \\
1,001,000 \\
22,000\end{array}$ & $\begin{array}{r}\$ 3,295,925 \\
2,546,400 \\
5,000,000 \\
300,300 \\
56,200 \\
345,000 \\
74,300 \\
\ldots \ldots \ldots . .\end{array}$ \\
\hline Total............ & $\$ 22,218,950$ & $\$ 12,324,000$ & $\$ 111,618,125$ \\
\hline
\end{tabular}

Total holdings of stock, $\$ 33,837,075$ par value.

On the other hand, the railways held, June $30,1906, \$ 20,668,000$ of express company stock (p. 19).

Of the $\$ 18,417,132,238$ outstanding railway securities June 30 , 1910, $\$ 5,100,814,274$ was held by railway corporations. Statistics of the Railroads, 1910, p. 52. 
the total number of shareholders would be 201,333 . This change, hidden among the statistics of other companies, the Wall Street Journal would herald as a remarkable diffusion of ownership. It is not intended to intimate that the writer in question could perpetrate so obvious a fallacy; yet to an analogous error, more serious because better concealed, he has certainly fallen victim. What is the average holding of a shareholder in these two hundred and fortytwo corporations? \$10,3I3? The data do not warrant the conclusion. How many shareholders are in this army? It is impossible to say at present; surely less than 872,392 .

Perhaps further criticism is unnecessary, but clearness may be gained by a consideration of the extent of that change of distribution of ownership claimed in the second of the quoted conclusions. In I9OI, according to the table, the corporations reported outstanding stock of a par value of $\$ 5,559,275,316$, in the hands of 226,480 shareholders. Now in this total of over five and a half billions, is included $\$ \mathrm{I}, 46 \mathrm{I}, 709,545$, the capitalization of thirty-eight companies which failed to make public the numbers of their shareholders. For three companies, owned by 5,2 I 5 persons, the capital was not recorded. Correcting for these two errors of opposite tendency, it appears that the average block in those corporations which reported both items was $\$ 18,519$, $\$ 6,027$ less than the $\$ 24,546$ of the table. Likewise in the totals for I9I I are included II,I 54 stockholders the aggregate value of whose interests is not given, and $\$ 12,905,200$, the capital of concerns not numbering their owners. These corrections raise the average holdings by $\$$ I I 9 , to $\$ 10,432$. Thus, whereas the reduction of the average block according to the figures of the Wall Street Journal was $\$ 14,233$, or fifty-eight per cent of $\$ 24,546$, the actual diminution was $\$ 8.087$, or forty-four per cent of $\$ 18,519$. The Journal's figures, therefore, exaggerate the rate of decrease by over 
thirty per cent and the absolute reduction by seventy-five per cent. ${ }^{1}$

It appears, therefore, that any conclusions as to the num-

1 Suppose there actually were 872,000 individual stockowners in these corporations, what is the distribution of holdings among them? In 1880, 42,262 men owned $\$ 327,185,500$ in government bonds, an average of nearly $\$ 8,000$. However, 13,309 of these men owned an aggregate of but $\$ 4,067,050$-an average of $\$ 306$; and 830 held $\$ 176,239,350$-an average of over $\$ 212,000$. In other words, two per cent of the male bondholders owned over half the bonds held by men. The details are as follows :

HOLDERS OF REGISTERED UNITED STATES BONDS, I 880

\begin{tabular}{|c|c|c|c|c|c|c|}
\hline I. & II. & III. & IV. & V. & VI. & VII. \\
\hline & \multicolumn{3}{|c|}{ Number of holders. } & \multicolumn{3}{|c|}{ Amount of holdings by } \\
\hline Size of holding. & 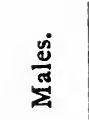 & 䢰 & 它 & $\frac{\dot{0}}{\stackrel{⿹}{J}}$ & 离 & 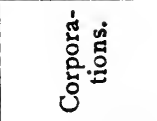 \\
\hline$\$ 50,000$-over .... & 830 & 168 & 531 & $\$ 176,2.39,35^{\circ}$ & $\$ 22,344,900$ & $\$ 210,695,150$ \\
\hline $25,000-\$ 50,000 \ldots$ & 1,018 & 281 & 224 & $38,668,100$ & $10,747,850$ & $9,3^{1} 4,650$ \\
\hline $10,000-25,000 \ldots$ & 2,326 & 953 & 259 & $38,861,750$ & $15,395,600$ & $4,886,5 \mathrm{co}$ \\
\hline $5,000-10,000 \ldots$ & 3,416 & $1,57 \mathrm{I}$ & 196 & $27,090,900$ & $12,235,400$ & $1,753,600$ \\
\hline $2,500-5,00(1)$ & 5,490 & 2,861 & 149 & $21,406,300$ & I $1,032,950$ & $63 \mathrm{I}, 7 \mathrm{CO}$ \\
\hline $1,000-\quad 2,500$. & 7,505 & 4,871 & 53 & $13,402,300$ & $8,532,850$ & 97,400 \\
\hline $500-\quad 1,000 \ldots$ & 8,368 & 6,372 & 59 & $7,449,75^{\circ}$ & $5,591,100$ & 56,400 \\
\hline $50-\quad 500$ & 13,309 & I 2,248 & 56 & $4,067,050$ & $3,47^{2,700}$ & 16,150 \\
\hline Totals ...... & 42,262 & 29,325 & 1,527 & $\$ 327,185,500$ & $\$ 90,353,350$ & $\$ 227,45^{1,55^{\circ}}$ \\
\hline
\end{tabular}

Tenth Census of the United States, Public Indebtedness, p. 235. The United States Steel Corporation and the International Paper Company have been selling stock on easy terms to their employees. Such a policy might largely increase the number of stockholders and decrease the average block without in the slightest impairing or altering the size of the blocks owned by individuals at the inauguration of the plan. Thus conclusions based on these averages are particularly illusory. 
ber of persons in the United States deriving incomes from the ownership of property, real or industrial, must be based more upon speculation than upon facts. It is not denied that the ownership of stock companies may be in a process of diffusion; the simple fact is that the magnitude of this extension, the character of the distribution is not known. ${ }^{1}$

Incomes of the third class are neither the rewards of labor, nor the returns to the owner of productive property. For want of a better term, they may be said to arise from the RIGHT OF PRIVATE PROPERTY ; they include, mainly, gifts, bequests, and inheritances. "That the inheritance is an income to him who secures it there can be no doubt." ${ }_{2}$ A peculiarity of income from the right of private property is that it is not normally a part of the distribution of products, but is rather a transfer of the ownership of capital. In a completely socialized state, whether or not interest were legally abolished, there would still be incomes from labor, and income from capital; but there would be no incomes from the right of private property-save perhaps small inheritances of personal effects. Incomes from the right of private property differ from such windfalls as speculative

${ }^{1}$ In 1904 the total stock of the American Railways, $\$ 6,339,899,329$ (Statistical Abstract of the United States, 1908, p. 256), was owned in 327,85 I blocks. According to the I9I f figures of the Wall Street Jour$n a l$, about forty railways with a stock issue of $\$ 3,658,760,390$ were owned in 290,145 blocks. The eighteen railway companies reporting stock lists in I90I and I9I s show a total of $61,96 \mathrm{I}$ holders at the earlier, and 138,406 at the later date. Probably greater diffusion of ownership plays some part in this enormous increase, yet the warning of Martin A. Knapp must not be forgotten: "It cannot, however, be said that this figure $(327,851)$ accurately represents the number of individuals interested in railway securities. ... To the extent to which the same individual is an investor in the stock of more than one company, the above figure includes duplications." Sen. Doc. no. 188, 58th Cong., 3 d Ses.

${ }^{2}$ H. C. Adams, Finance, p. 360. 
profits in that, except in such cases as those involving the capture of affections, they do not as a rule presuppose the element of shrewdiness or the control of capital. Although the sum of inheritances in the United States in any one year must be considerable, it is not a great factor in the nature of the distribution of regular incomes in this sense, that the inheritance is, if large, normally a transfer between individuals of an income from property ownership.

The importance of these incomes from the right of private property is better known abroad than it is in the United States. During the years 1903 to 1907, among the French population of approximately $38,333,000$, there were annually about 780,000 deaths, an average of 356,3 Io, over forty-five per cent, of these decedents leaving estates of one franc or more. Nineteen per cent $\left(148,55^{6}\right)$ of those who died were possessed of property worth not less than $\mathfrak{E}$ Ioo. In England, by way of contrast, but nine and four-tenths per cent of the 546,000 decedents left estates valued as high as $\mathfrak{f r o o}^{1} \quad$ A curious custom in France is that of the father handing over property to his son some time before death (donations); in the course of the year these gifts have amounted to one-seventh, and at times almost to a fourth of the inheritances. ${ }^{2}$ Only three and eight-tenths per cent of the decedents in England leave property to the amount of $\mathfrak{E r , O o O}$ or over. The following table gives interesting details of inheritances in France and England.

${ }^{1}$ Journal of the Royal Statistical Society, June, I9Io, vol. 73, p. 636.

'Ibid., 1893, vol. 56, p. 600. 


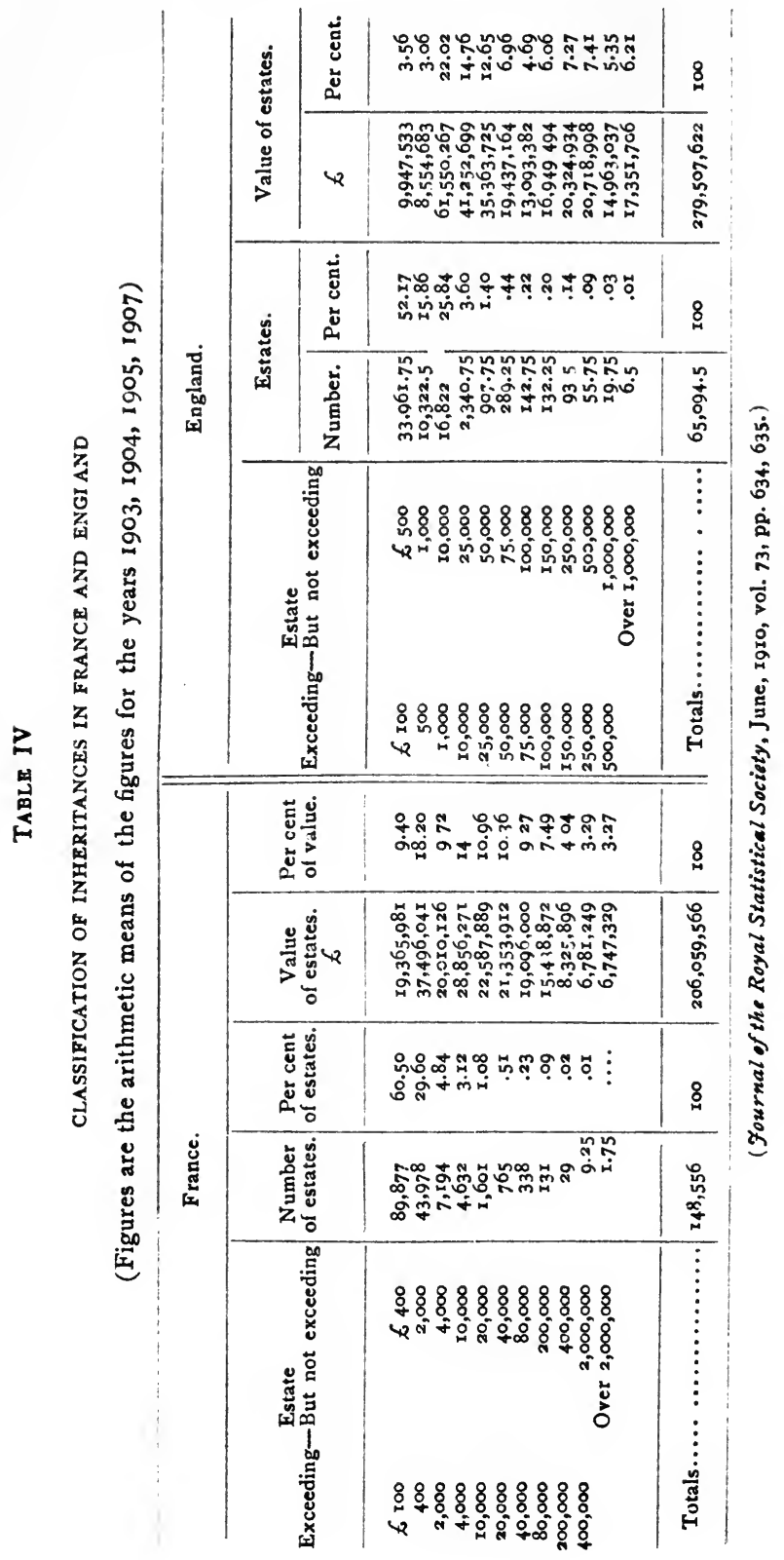


Possibly because of the blessings of decentralized government, the United States has no general inheritance tax. Although several of the commonwealths have instituted such duties, but few classified returns are available. In the aggregate value of property, New York is certainly the richest of the states, and her per capita wealth is surpassed probably only in the District of Columbia, Nebraska, Montana, Wyoming, Colorado, Arizona, Nevada, Oregon, and California. $^{1}$ Between 1904 and 1908, the average annual number of deaths in New York was about I41,000, and the mean number of estates taxed as being worth $\$ 5$,ooo or more was 5,900 ; thus about four per cent of the decedents in the Empire State leave property worth as much as $\$ 5,000$. Of the 138,883 persons who died in $1908,47,202$ were males over twenty-five years of age. ${ }^{2}$ In that year 6,233 estates were taxed. Thus, in one of the richest commonwealths in the Union only one man in eight dies worth $\$ 5,000$. Further than this it is impossible to go, as no record is kept of the total values of all the estates taxed.

There are, then, three sources of income, labor, the ownership of property, and the right of private property. Incomes from labor, the rewards of personal exertion, may be subdivided into three classes, salaries which are enjoyed by about one-tenth of the gainfully employed, wages which are earned by approximately six-tenths, and contingent incomes which accrue to the remaining three-tenths. Among the employed, the salary seems to be gaining over the wage

${ }^{1}$ Census, Weealth, Debt, and Taxation, 1904, pp. 42, 44.

${ }^{2}$ Calculated from figures in Mortality Statistics, 1908, Bureau of the Census, pp. 368, 454; see also pp. 103. 120. From the Reports of the Comptroller of the State of New York, it appears that the number of estates taxed in 1905 was 5,431 ; in $1906,5,88 \mathrm{I}$; in $1907,6,04 \mathrm{I}$, and in 1908, 6,233-average, 5,897. After 1908 only the number of appraisals is given; not all appraisals result in a tax. Reports, 1906, p. xlii; 1908, p. xlix; 1909, p. xxxii. 
as the preferred method of remuneration. A determination of the number of persons enjoying incomes from property is impossible on the basis of existing data; it is not known how many persons are interested in real estate, how many are holders of industrial or railroad stocks, or how many own United States bonds. Finally, for the last three years not even the aggregate value of the estates of at least $\$ 5,000$ actually taxed in New York has been made available. It is therefore apparent that the people of the United States are in profound ignorance of the sources from which they derive their incomes. ${ }^{1}$

${ }^{1}$ Dr. Spahr, in his Essay on the Present Distribution of Wealth in the United States, pp. 88-92, 120, has concluded that in Basel, France, Saxony, the United Kingdom, and the United States, forty per cent of the national income goes to capital and sixty per cent to labor. Recent available figures for eight large American industries, employing over three million laborers, give to capital a return in dividends and interest of $\$ \mathrm{I}, 276,4 \mathrm{I}, 050$, and to labor in salaries and wages of $\$ 2,03 \mathrm{I}, 402,2 \mathrm{IO}$, a total income of $\$ 3,307,821,260$, of which the share of labor is sixtyone per cent, and that of capital thirty-nine per cent. That these figures are typical of the whole field of American industry is questionable.

RETURNS OF CAPITAL AND LABOR IN EIGHT INDUSTRIES

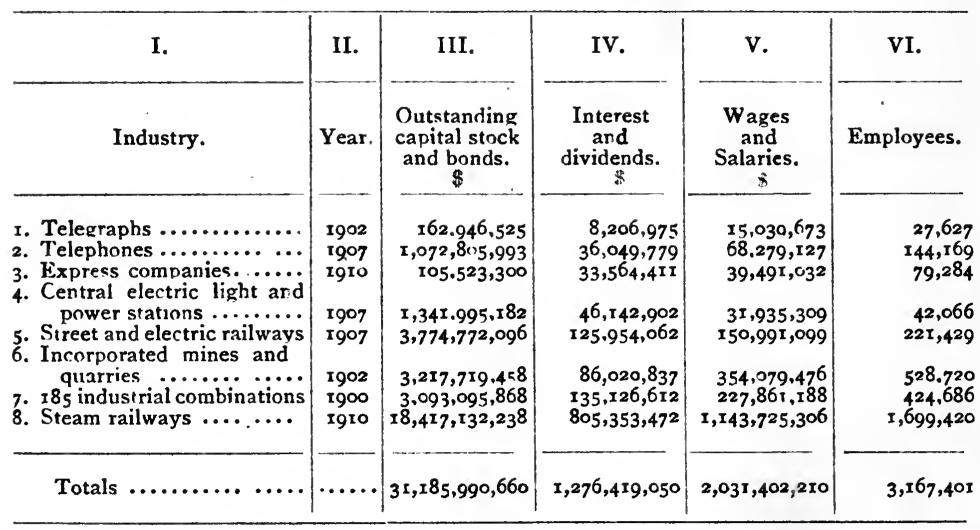


References-Special Census Reports:

I. Telephones and Telegraphs, 1902, p. 99.

2. Telephones, 1907, pp. 57, 59, $7 \mathrm{I}$.

3. Interstate Commerce Commission, Report on Statistics of Express Companies for year ending June 30, 1910, pp. I5, 30. The dividends are abnormal, including a $\$ 24,000,000$ dividend by the Wells Fargo Company (capital $\$ 12,000,000$ ) -wages and salaries, and number of employees from Census Bulletin, Express Business in the United States, 1907, pp. 14,15 .

4. Central Elec. Light and Pozver Stations, I907, pp. 61, 89, 92 (commercial).

5. Street and Electric Railways, 1907, pp. 97, 193.

6. Mines and Quarries, 1902, pp. 88, 68, 72.

7. Manufactures, I900, pt. ii, pp. 1xxix-1xxxvi (interest of $\$ 216,412$,759 worth of bonds not reported).

8. Statistics of the Railways, I910, pp. 33, 44, 50, 5I, 55, 57. 


\section{CHAPTER IV}

The Sources of American Income Statistics

Since, as was shown in the previous chapter, not even the number of persons enjoying incomes from the ownership of property and from the right of private property is known, it is presumptuous to expect to find any figures of the distribution of these revenues. The rewards of labor, on the other hand, have long attracted the attention of the statisticians. American statistics of annual incomes, it is true, are scanty enough, but a great mass of wage data has been published by the state bureaus of labor and by the Federal Government.

A detailed description of these state reports is unnecessary, but it may be well to point out just what material they offer to the serious investigator of the distribution of incomes. It must constantly be borne in mind, that in the various commonwealths the purposes of these bureaus are very different. For example, judging simply by their reports, some of the states, especially in the west, conceive of a labor or industrial commission as an advertising agency, the prime purpose of which is to attract immigration of men and capital. The natural result of such a concept is the publication of some photographs of genuine artistic merit, and a series of vague, but glowing, generalizations, printed in beautiful type and supported by a few figures apparently conjured out of the air, or deduced by introspection. Other states devote their energies largely to studying the "industrial opportunities" in each town or county, to 46 
a manufacturing or labor " chronology", to directories of organizations, to studies of accidents in factories and mines, to attempts at conciliation in labor disputes, to special investigations resulting in monographs, or to the compilation of various classes of industrial data. Indeed, one unfamiliar with them would be surprised at the multi-form activities of the state bureaus of labor. The reports of Massachusetts, New Jersey, New York, Wisconsin, and Illinois in particular abound in valuable articles on special subjects. Therefore to condemn the reports of the majority of the state labcr departments, simply because they contain no adequate wage data, would be rank injustice: what follows relates only to their offering of material to aid in a study of incomes. However, it can in fairness be said that in very few states have there been exhibited both an appreciation of the importance of collecting such statistics and a knowledge of valuable methods of gathering and presenting them. In none has there been made an extensive study of annual incomes.

Rather limited compilations of yearly incomes and earnings, however, have until recently, been made annually in Kansas and biennially in Iowa. ${ }^{1}$ In the labor reports of these states have been incorporated the complete individual replies to an elaborate questionnaire sent out to working men of many occupations, including even "clerks". Among the questions is one calling for the total earnings during the year, in Kansas, income also, and another asking whether the worker has a family dependent upon him for support. These data have much to commend them. First, from the individual returns the investigator can make any tabulation he finds useful. Second, the earnings for a year being given, the allowance for unemployment is automati-

${ }^{1} 1907$ is the last year for which Kansas compiled these statistics. 
cally made. Third, the same system has been followed for a series of years, thus allowing some estimate of the shorttime trend of wages. Fourth, the replies are from mature men, nearly all of whom are heads of families; this is a decided advantage over so many statistical presentations wherein all males over sixteen or over twenty years of age are included in the same tabulation. Fifth, the data cover occupations but scantily touched, if at all in the other compilations of wage statistics, which are so frequently confined to manufactures; and in addition the studies are statewide. There is, therefore, much to commend this part of the work of the Kansas and Iowa Bureaus of Labor, but there are some countervailing weaknesses: First, four or five hundred cases is a rather small sample to be surely representative of the conditions even in a thinly-populated state. Second, as about twenty occupations are included, the number in each must be quite limited. Third, the returns are almost universally from members of trade-unions, and cannot, therefore, be used to shed any light upon the condition of non-union men, or of workers " in general ". Fourth, it is not improbable that the men who have the ability and the interest to fill out such long blanks, are rather above the "average" in intelligence and consequently in earning power. Fifth, it is sometimes questioned whether any workmen are capable of accurately answering questions regarding their financial status. But this danger can hardly be considered serious, for although it is difficult to "keep accounts", absolute exactness of the individual returns is not a necessity to good statistics; it is probable that the errors are at least partially compensating, and, if his pay is small, a man is not likely to make a very large mistake in estimating his earnings. In brief, then, these two states furnish data which, if used with care, are of considerable value. 
For the sake of completeness, three recent studies should be mentioned. The report of the Wisconsin Bureau of Labor Statistics for 1907-1908 gives the classified incomes of eighty-two families, female members of which were employed in the Milwaukee tanneries. The 1906 and 1908 reports of the Illinois Bureau of Labor contain the results of searching investigations among the women employed in factories and in department stores. For those women whose names appeared on fifty or more weekly pay rolls, the total earnings during the year are given, individually, and in classified tables. A large number of individuals is included in each case, and there is good ground for believing that the statistics are truly typical. The number of girls in the department stores whose wages are given is 2,556 , but the annual earnings of only 1,660 are presented. ${ }^{1}$ What were the incomes of the other 896 ? Their case is just as interesting as that of the full-time workers; whether the unemployment was voluntary or involuntary, their problems are doubtless more acute. The income of the person who is steadily employed can be determined just as well from the weekly as from the yearly earnings; in order to estimate the welfare of those who suffer from idleness, their annual incomes must be known. This should not be construed as adverse criticism of the excellent report under discussion, it is merely evidence that the most-needed information is hardest to obtain. It seems, then, that a search through the state publications for statistics of annual incomes, or family earnings is fruitless so far as results of general applicability are concerned; but in certain limited fields, Kansas, Iowa, Illinois, and Wisconsin offer valuable material.

If annual earnings have not been tabulated, there are still large possibilities in the statistics of classified wages. These

1 Biennial Report, Bureau of Labor Statistics, Illinois, 1908, pp. 426, 445 . 
are regularly furnished by four states. The Wisconsin Bureau of Labor early undertook a regular publication of such figures; Massachusetts adopted the plan the very same year, 1889, New Jersey in 1896, and Kansas in 1900. All four of these commonwealths still furnish these annual tables of classified wages of the employees in manufacturing industries. Kansas adds similar information concerning the miners and meatpackers. ${ }^{1}$ Wisconsin presents a compilation of daily pay, distinguishing males and females; the other three states tabulate weekly wages and distinguish men, women, and children or young persons. ${ }^{2}$ In each of these states, every important manufacturing industry is accorded separate presentation, and a summary is made for all industries. These reports undoubtedly contain the best wage statistics that are regularly made available in the United States to-day. In the first place, the classified presentation shows how earnings are distributed-averages alone could not do this. Second, continued use of a good method allows a study of the trend of wages from year to year. Third, an accurate comparison of the conditions of employment in the different groups of industry is made possible. Fourth, the figures are furnished regularly by manufacturers from their books, and should, therefore, be as exact as it is possible for statistics to be. Fifth, supplementary data regarding the state of employment, the proportion of business done in the industry, and the hours of labor are available, especially for Massachusetts and New Jersey. Sixth, the returns are complete, covering nearly every factory wage-worker in each of the states. With

1 The rgI Kansas report, the latest, omits these statistics. It is to be hoped that the omission is for one year only.

${ }^{2}$ In Kansas and New Jersey employees under sixteen years of age are reckoned children; in Massachusetts those under twenty-one are styled young persons. 
all these merits there are some minor defects. First, except in the Wisconsin reports, the distribution is not given for the extremes, the groups being " under \$3" and "\$25 and over", and the classes are not uniform, running " $\$ 8$ but under \$9 ”, “\$9 but under \$10”, “ \$10 but under \$12”, “\$1 2 but under $\$ I_{5} ", " \$ I_{5}$ but under $\$ 20 ":$ this is a defect for some theoretic purposes, interpolation not being entirely satisfactory. Second, as the data refer to one week only, it is impossible to draw safe conclusions as to the annual earnings. Third, the practice of some bureaus of having each firm make returns for its "busy week", the week of largest employment, makes it impossible to be sure that duplications are avoided; that is, the same individual may figure in the statistics from more than one concern: probably, however, no better week could be chosen as a sample, although a normal or typical week, as used by Wisconsin, might serve. Fourth, a suspicion has been expressed that the manufacturers are not always as careful as they might be to have the replies accurate, the filling of detailed questionnaires is expensive; there may be a difference between the possibility and the probability of securing exact figures from the books of the employer, if he does the compiling. Fifth, the average weekly earnings are not given except in Wisconsin. Taken all in all, however, the wage data furnished by these four commonwealths is unequaled in the United States for scope and method, and reliability.

The valuable data furnished in these reports for factory operatives are supplemented by the publications of New York. In the annual reports of the Bureau of Labor Statistics, appear what amount to the individual returns of the total earnings of the men and women trade-unionists during the first quarter and during the third quarter of the year. These are summarized by trade groups, and the earnings classified as being, for the three months, "less than 
$\$ 75$ ”, “\$75 to \$I49”, “\$I 50 to \$224”, “\$225 and over ”. The raw material for this compilation is furnished by the secretaries of the locals, and may, therefore, be more or less inaccurate. New York's policy has been open to objection also on the ground that the figures cover only organized workers. In a way, these criticisms are both well taken. Yet it cannot be denied that, in furnishing regularly statistics of the earnings of union men and women, a unique service is rendered; although it might be wished, perhaps, that the earnings of unorganized workers were given in parallel columns for the sake of comparison. But with such excellent wage data for the employees of the manufacturers furnished by the neighboring states of New Jersey and Massachusetts, it is surely an advantage to have New York spend its energies in investigating the building trades, public employment, theaters and music, and transportation. Of course the conditions in no two states are exactly alike, and yet, until larger appropriations are available, a division of tasks seems wise. Finally, the adoption of three months instead of the week as the unit of time seems to be a step in advance; on the other hand, it would be well to have the income group intervals in the summaries smaller, say twenty-five instead of seventy-five dollars. On the whole, then, New York's contribution is inferior to none.

Besides these five states which regularly present classified statistics, there are a number which publish averages, sometimes minutely subdivided with regard to sex, industry, occupation, and locality. Chief among these commonwealths is Ohio; but Pennsylvania, Michigan, Missouri, Washington, and Tennessee compile some excellent figures of this class. The other state bureaus, with occasional exceptions, print no wage data worthy the name. With respect to salaries. a few means are to be found in the Ohio, Michigan, and Missouri reports, but the information is hardly in usable form; and of contingent incomes, no figures are published. 
Since but five states publish classified wage statistics, and only two have made any pretense of securing periodic data upon annual earnings, very little can be gained for a study of the Distribution of Incomes from these reports. Much that is valuable should be credited to these bureaus of labor, but, to say the least, they fail to throw a flood of light upon the important problem of this essay. Therefore, recourse must be had to federal sources. Among the publications of the Census, the Bureau of Labor, and the Department of Agriculture, there appears, at first blush, an enormous amount of pertinent data-not, to be sure, information dealing directly with incomes, but what are, nevertheless, desirable wage studies. In order to determine just what is available for the purpose of this essay, it will be well to subject these figures to closer scrutiny.

By all odds the best of the Census wage data are to be found in the study entitled Employees and Wages, a special volume published in 1903, and known, because it was prepared under the supervision of Professor Davis Rich Dewey, as the "Dewey Report". For a large number of factory employees, male and female, above and below the sixteen-year line, the hourly and weekly wages are minutely classified. Separate presentations are accorded to the chief occupations of each of thirty-four leading manufacturing industries, the absolute numbers and the cumulative per cents in the several pay groups for 1890 and 1900 in identical establishments being set down in parallel columns. A further distinction is drawn between the different sections of the country. This report has many merits, among which may be mentioned: first, that the collection and the criticism of the data seems to have been more intelligently painstaking in this investigation than in any other; second, that the classification is so minute that many rearrangements are possible at the will of the student; third, that, as the occu- 
pational figures for I890 and I900 are published in parallel columns, it is possible to compare the wages paid by identical establishments for the two periods; fourth, that piece pay is put upon a time basis. Thus, the Dewey Report has the three prime virtues of a statistical publication, accuracy, detailed presentation, and a foundation for comparisons; yet, in certain respects, it might have been rendered more serviceable. First, there is no summary either for all the male factory employees, or for all those having the same occupation though employed in different industries, or for all those in one section of the country. Thus, the student being lost in a mass of detail, any general idea of the state of wages is impossible, as few persons have the ability, the facilities, and the time, to make their own summaries from such minute classifications. It was not until four years after the publication of the Dewey Report that Professor Moore made generally available a summary of its contents so far as they concerned adult males. Second, rates of pay are published, and, as has been pointed out, the whole effect of unemployment is necessarily neglected. This, however, is a disadvantage which attaches itself to nearly every wage study and will not be referred to again, although it should be kept constantly in mind. It might be wished that the scope of this investigation had been extended beyond the somewhat narrow field of manufactures, but the task would probably have been too great for one effort. At any rate, the Dewey Report is a model of most that is desirable in a work on wages.

In addition to this excellent Dervey Report, the Twelfth Census, in the volume on Mines and Quarries, offers statistics of the classified wages of the employees of "incorporated companies". Separate presentations are given for each branch of mining in which a thousand or more wageearners are employed, including anthracite and bituminous 
coal, copper, lead, iron, gold, and silver, and for mines and quarries as a whole. The value of these figures is impaired by the following considerations: first, no occupational divisions are made, inside and outside workmen, for instance, being included in the same tabulation; second, no distinction is made for age, I I,857 boys being included among the total of 58I,728 employees; third, mining and quarrying as a whole are not perfectly represented by the incorporated companies; fourth, the demand for labor in mining coal is notoriously irregular. On the other hand, the choice of the classified method of presentation is a great step in advance of most wage studies, and one should remember that this investigation of earnings was but an incidental part of a much larger study.

Never intended to reveal incomes, the Twefth Census, ${ }^{1}$ in the report on Agriculture, presents a tabulation of farms by the "Value of Products of I 899 not fed to Live Stock." This classification would be exactly what is needed to show the distribution of incomes among farmers were it not that two important allowances ought first to be made. A large proportion of farmers find it necessary to employ outside help, and another group hire their lands. Obviously unless wages and rent are first subtracted from the product, the amount available to the agricultural family for actual enjoyment is not disclosed. It may be asked why rent should be deducted from the income of the farmer, and not from that of the urbanite. The answer is that the rent paid by the agriculturalist is largely one of his costs of production; he hires acres somewhat as others borrow capital; shelter for himself and family is only one consideration. In spite of their shortcomings for this purpose, these tables may be used to show with some precision the number of farm families whose in-

' Vol. v, Agriculture, pt. i, pp. lix et seq. 
comes do not exceed a certain minimum. This use, however, is liable to one source of error which may be very important. In the case of some farmers, instead of a subtraction for rent and wages, an addition should be made for the return from a second place owned and let out; the number of such cases is unknown. The use of these tables in a study of the distribution of incomes, is, therefore, limited.

The schedules of the Census of Manufactures, taken in I 905 to cover the year 1904, called for classifications of the wages of men, women, and children under sixteen years of age. These returns were compiled in a table covering some $3,297,819$ individual operatives of whom 2,619,053 were men. ${ }^{1}$ Upon this basis, an estimate was made for the five and a half million wage-earners employed in all the manufacturing establishments of the United States. This estimate was derived with great care, the distribution of earnings in each industry being calculated separately for the average number of persons of each class employed in 1904; what was lacking in the Dewey Report was here supplied. The good features of this study may be mentioned: first, a broad base was used, forty-seven per cent of the factory wage-earners being included; second, not rates but earnings for the busy week were tabulated; third, the returns were prepared from actual records, verbal statements being accepted only in case there were less than ten employed in an establishment; fourth, the summary is excellently presented. Yet there are some things that might have been wished. In the first place, no details are given for those paid less than \$3 per week, and such important groups as "\$10 to \$I2", and " $\$ 12$ to $\$ 15$ " might better have been broken into classes with a one-dollar interval. This, however, is not a

${ }^{1}$ Special Reports of the Census Office, Manufactures, 1905, pt. iv, pp. 645 et seq. 
vital point, particularly when one recalls the classification used in Massachusetts, New Jersey, and Kansas, and the fact that a more minute grouping would have made cumbrous the publication of the details by industries and by states. In the second place, there is a justifiable suspicion that the collection of the data was not as careful as might have been desired. ${ }^{1}$ How much allowance should be made for carelessness of special agents is a question that cannot be answered. It would seem safe to assume that the estimates of proprietors would not minimize wages, and that a check was placed upon the size of errors by comparisons of the wage classification in each establishment with the amount of the weekly pay roll. ${ }^{2}$ Finally, the marked similarity between the results of the Census of 1905 and the Dewey Report would seem to indicate approximate accuracy. ${ }^{3}$

In a special report upon Central Electric Light and Power Plants, 1902, the Census Bureau compiled the classified daily wages of the 18,878 employees in the most important occupations of about eighty per cent of the stations in the country. This seems to be the only other Census publication that thoroughly treats the subject of wages, although in the bulletins on the Express Business, Telephones and Telegraphs, Street Railways, and the Shipping Industry, many averages are presented.

There are, then, four recent reports of the Census office which are of service in a study of the distribution of in-

1 "There is every reason to believe that at prior censuses the information in most cases was not taken from actual records, but was based on more or less inaccurate estimates of the operator of the factory." E. Dana Durand, Quarterly Pub. American Statistical Association, vol. xii, p. 65, March, 1910.

'Census, Manufactures, 1905, pt. iv, p. 644, a.

3 Infra, p. 99. 
comes; two of them deal with wages in manufactures, one with the pay of miners and quarrymen, and one with the receipts of farm families. Each of these investigations has certain defects for the purpose of this essay, and yet each, having also many excellencies, may furnish valuable material. The principal regret is that the field covered is so narrow, no effort having been made to study the wages of agricultural laborers, railway employees, and many other large groups of workingmen. A second sorrow is that the Thirteenth Census is to include no investigation of this important subject, and, consequently, in comparison with the new population and occupational figures now appearing, the available income statistics will seem even more ancient. It may be because the Census has done so much, that it seems to have left so much undone.

Satisfactory data not being found in the Census publications, it is natural to look elsewhere. As farming is such a fundamental branch of enterprise, and as labor forms so important a part of the cost of producing crops, it is reasonable to suppose that the Department of Agriculture would be able to furnish good wage statistics. And yet the search for adequate figures is vain. True, some nineteen or twenty studies have been made, but the total result is a collection of averages so general that they are almost devoid of meaning. Perhaps this use of the average may be justified: the employer wants to know what a hired man ought to cost him, and the average tells that well enough. Doubtless this is in a measure true, and yet, even from the viewpoint of the farmer it might be better to know the range and the distribution of wages; to know what must be paid for a good hand and what is the price of a poor one. But waving this as impracticable, the arithmetic mean has no significance to the agricultural laborer; it does not tell him what he can reasonably expect, nor how peculiar efficiency will be re- 
warded. If the problem of securing farm labor is really as acute as it is pictured, the figures which would allure men into the field would be those showing classified annual earnings, and the chances for a hired man to rise to ownershipprovided these figures are attractive when compiled. Significant for this essay is the fact that there are no good statistics of the distribution of earnings among agricultural workers.

Another federal organization that compiles wage statistics on a large scale is the Interstate Commerce Commission. In the Statistics of the Railways, there are regularly tables showing separately for the ten geographic groups and for the country as a whole, the average daily rates of pay of the employees in each large occupational division-general officers, office clerks, station agents, and conductors, for example. Highly probable it may be that in a given occupation remuneration is fairly uniform, nevertheless, it is unsafe to accept, with Professor Nearing, these daily averages, as an indication of the distribution of annual incomes among the labor force. Then, too, there are some women among the employees of these carriers, but they are not distinguished in the tables. This, however, is not a matter of great importance, since in I900 only 1,688 of the 582,150 railway workers were females. ${ }^{1}$ Members of the Interstate Commerce Commission correctly believe that for inclusiveness and accuracy their wage data are unsurpassed.

Special documents submitted to Congress contain a great deal of scattered and often unusable material relevant to the subject of distribution of incomes. One of the most recent of these, for instance, the Report of the Select Committee on Wages and Prices of Commodities, ${ }^{2}$ is little more than a

1 Abstract of the Twelfth Census, p. 25.

2 Sen. Doc. no. 847 , 61st Cong., 3d Ses. 
new edition of data already available in other federal publications. Although here and there the testimony of an individual brings out a few particular facts as to wages in some one branch of industry, these persons speak only from their own more or less limited experience, and their information cannot be considered sufficient for statistical use.

There remains for consideration the work of one other federal agency. Upon the Bureau of Labor naturally falls the duty of providing information relative to standards of living in the United States, and to the distribution of the means of maintaining those standards. The Eighteenth Annual Report of the Commissioner of Labor (I903), well conceived and skilfully executed, is the most extensive existing compendium of material upon these subjects. Although the title of this study was "The Cost of Living", the subject was treated so broadly as to make it useful in many different lines of research. Special agents visited at random working-class families. An attempt was made to distribute these households among the various industries approximately in proportion to their importance, and among the commonwealths according to population; thus the final result may be considered fairly typical of the whole United States. It was further intended to deal only with families having a total income not over $\$ \mathrm{I}, 200$. Both these aims seem to have been fairly achieved. The agents secured answers to quite an elaborate set of questions, calculated to show the amount and the composition of the income, the details of its expenditure, and the membership of the households. In all, 25,440 schedules were returned. The wages for the year of the 24,402 male heads of families were classified, by occupations and by industries, in one-hundred-dollar groups, and thus were made to afford an excellent presentation of the distribution of annual earnings among mature men in the industrial pursuits. There are many 
reasons for commending this report. First, the information was gathered by trained special agents, and an endeavor was made to secure consistency in each return by various checking expedients. ${ }^{1}$ Second, classification is undoubtedly the best arrangement of data on incomes, earnings, and unemployment. Third, annual compensations, not wage rates, are tabulated. Fourth, the remuneration of heads of families is presented; it is an important question whether the mature man is able by his own exertion to support a home. Fifth, great effort was made to have the result typical of the entire industrial people of the United States. Sixth, the base is the broadest in all the American studies of household budgets and revenues. From the standpoint of the student of Social Science, this Eighteenth Annual Report of the Commissioner of Labor is certainly the best index of the possibilities of the American workingman for self realization. As a treatment of the distribution of incomes, however, it leaves something to be desired. In the first place, the schedules apply to the years 1900, I901, and 1902, and consequently, it is questionable whether in this rapidly-developing country, the conclusions as to the distribution of earnings are still valid. In the second place, although many occupations were represented among the twenty-four thousand men, only fifty-seven trades contributed as many as a hundred schedules each. Moreover, as the investigation was confined largely to families having incomes not over $\$ 1,200$, the tables cannot show the exact state of affairs except in those occupations where the absolute high limit of earnings is $\$ \mathrm{I}, 200$ or less. These two facts considerably narrow the usefulness of this report. Finally, the nomenclature of occupations is not identical with that of the Census. In spite of these limitations, the results of this investigation may prove to be of great value.

${ }^{1}$ For details, consult the opening pages of the report itself. 
Studies, similar in general scope to that just discussed, have been made in the cotton, woolen, and glass industries, but they are too old for use to-day. In the bi-monthly Bulletins of the Bureau of Labor there are many articles on wages, but none of any importance presents classified data. Until 1907, an index number of wages was annually published. Although some criticism might be passed upon the method of computing this index, it had the merit of taking into consideration the rates of pay in the building trades as well as in manufactures. Two recent special studies of the Bureau of Labor deserve mention, the Report on the Strike at the Bethlehem Steel Works, and the Investigation of Telephone Companies. ${ }^{1}$ The former presents classified hourly, and the latter monthly earnings. But these are both very special for the purposes of this essay. The latest work of the Bureau is the Report on Condition of Woman and Child Wage-Earners in the United States, ${ }^{2}$ in nineteen volumes. The method of arranging the data in this report is admirable, and the material has undoubtedly been collected with great care. The figures of earnings, however, relate almost exclusively to women, or children, or to men in occupations where women and children are normally employed, and are therefore of little value to this study.

This survey of the sources of information seems clearly to indicate that material for a convincing study of the distribution of incomes in the United States, does not exist. In this field, the Iowa and Kansas returns from individual workingmen being at once haphazard and too narrow in scope, the states have no regularly-organized statistics. Four commonwealths, however, Massachusetts, New Jersey, Kansas, and Wisconsin, periodically publish tables classify-

${ }^{1}$ Sen. Doc. nos. 521 and 380, 6rst Cong., $2 \mathrm{~d}$ Ses.

Sen. Doc. no. 645, 6rst Cong., $2 \mathrm{~d}$ Ses. 
ing the pay of factory operatives; and New York renders similar service for the quarterly earnings of organized workers. Only these five states furnish information in any way satisfactory for the purpose in hand. Nor does the Federal Government fully meet the need. The Dewey $R e$ port and the 1905 Census of Manufactures offer a mass of excellent wage data for the one branch of industry; the volumes on Mines and Quarries, and on Agriculture afford valuable hints; the Eighteenth Annual Report of the Commissioner of Labor furnishes a real tabulation of the distribution of earnings in certain occupations; special studies, excellent in their fields, are diverse in method, and rarely throw light on the problem. Thus is the conclusion enforced that a plain statement of the distribution of labor incomes in the United States is impossible.

So much for the statistics of labor earnings; even less satisfactory is the material for a study of other forms of income. In the Census is recorded the number of families, urban and rural, owning their dwellings; the value of this real estate is approximately known; but, as was pointed out in Chapter III, even in the case of farms, the number of owners cannot be ascertained from any published data, much less their returns from property. So far as they go, the accuracy and the value of the Census figures are not here questioned, but they are simply insufficient to show the distribution of real property in the United States.

Many valuable special investigations have been made by the Census Bureau, for instance, that of 1880 into the ownership of United States bonds, the summary of which was presented in Chapter III, and that of 1904 into the debts of the states and minor civil divisions. ${ }^{1}$ Other reports have been prepared on the Street Railways, the Tele-

${ }^{1}$ Census-Wealth, Debt and Taxation, 1904. 
phone Companies, the Telegraph Companies, Central Electric Light and Power Stations, and Mines and Quarries. All of these show the stock and bond capitalization, the interest, and the dividends, but they are inadequate for the present study, in that they give no idea of the number of stock and bond holders. In the Census of Mamufactures it is customary to print a warning against trying to determine net gain from the published figures, which are collected with the distinct understanding that profits are not to be revealed. There was, however, one departure from this policy when, in I900, the dividends of each of the I85 "Industrial Combinations" were published, but in this case no computation was made of the interest on the funded debt. It is, therefore, apparent that little aid can be expected from the Census publications.

The Interstate Commerce Commission annually compiles the book, already mentioned, entitled, Statistics of the Railway's. This volume includes excellent material on the earnings of both stocks and bonds, classifying the stocks according to the rate of dividend. The last two years have seen the beginning of a new publication by this Commission, the Report on Express Companies, which contains complete information as to the capitalization and earnings of these enterprises. But since the special computation of the number of stockholders in 1904, nothing has been done to show the public the number of persons owning railway or express securities.

Accurate figures of the capitalization and earnings of all classes of banks are published in the annual reports of the Comptroller of Currency. The new special excise tax on corporations has occasioned the introduction into the reports of the Secretary of the Treasury of a table showing the capitalization and net income of all the incorporated companies in the United States. 
For the data as to the capitalization and earnings of individual corporations, recourse must be had to private publications, such as the stock exchange manuals, and the financial journals.

The information in all of these publications has but one fault for the purpose of this study; the matter of ownership is not treated. There is no basis for the determination either of the number of recipients of property incomes, or of the distribution of these incomes according to size.

This completes the survey of the sources of material for a study of the distribution of incomes in the United States. It remains to point out what inferences have been drawn from the available data, what inferences are permissible, and what steps are necessary in order to secure adequate statistics. 


\section{CHAPTER V}

Previous Treatment of American Income Statistics

THE first elaborate study of the distribution of incomes in the United States was based upon very special sources. Although it is true that Dr. Charles B. Spahr both availed himself of official figures showing the distribution among individuals of taxable property in the rural portion of Massachusetts in 1873 and quoted from the 1890 Census returns of home ownership, his really constructive work was founded entirely upon an original compilation of the probate statistics of New York. Estates worth as much as $\$ 5,000$ were subject to an inheritance tax. It appeared that almost exactly one-eighth of the men who died after passing the twenty-fifth birthday, left such estates, and that the number of males over twenty-five years of age was practically identical with the number of private families. Consequently, the distribution of estates among dying men should be typical of the distribution of property among households. With this preface, the conclusions may be outlined in Dr. Spahr's own words:

The distribution of wealth in the whole state of New York is of less importance than the distribution in the district lying outside of the two great cities. This district is typical of the country at large; for if the distribution of property is wider in the distinctively agricultural states, it is much narrower in the excluded Metropolis. The table for the state at large, outside of New York and Brooklyn ran as follows: ${ }^{1}$

${ }^{1}$ The Present Distribution of Wealth in the United States, p. 64. Spahr's records covered thirty-six of the sixty-one counties. 
TABLE V

DISTRIBUTION OF ESTATES IN NEW YORK

\begin{tabular}{|c|c|c|c|c|}
\hline I. & II. & III. & IV. & v. \\
\hline Value of estates. & Number. & Realty. & Personalty. & Tutal. \\
\hline \multirow[t]{2}{*}{$\begin{array}{l}\$ 50,000 \text { or over } \ldots \ldots \ldots \ldots \ldots \ldots \\
5,000 \text { to } \$ 50,000 \ldots \ldots \ldots \ldots \ldots \\
\text { Under } \$ 5,000 \ldots \ldots \ldots \ldots \ldots\end{array}$} & $\begin{array}{r}36 \\
409 \\
1,427\end{array}$ & $\begin{array}{r}\$ 2,188,540 \\
2,950,325 \\
989,608\end{array}$ & $\begin{array}{r}\$ 6,606,123 \\
2,233,871 \\
1,095,430\end{array}$ & $\begin{array}{r}\$ 8,794,663 \\
5,184,196 \\
2,085,098\end{array}$ \\
\hline & 1,872 & $\$ 6,128,533$ & $\$ 9,935,424$ & $\$ 16,063,957$ \\
\hline
\end{tabular}

The table for New York City showed that one-eighth of all the families held more than $\$ 5,000$ worth of property. The census investigation of mortgages showed that about one-eighth of the farms of the country were worth more than $\$ 5,000$. With a normal death rate the table for New York outside the two great cities shows just the same proportion of well-to-do families. We may therefore say with much precision, that approximately one-eighth of the families of the nation, city, town, and country hold more than $\$ 5,000$. The proportion holding over $\$ 50,000$ is exceptionally great in the large cities, and exceptionally small in the country districts; but the proportion in the intermediate territory selected may be safely assumed for the entire nation. The table for the nation at large would therefore read: ${ }^{1}$

\section{TABLE VI}

SPAHR'S ESTIMATE OF DISTRIBUTION OF PROPERTY IN THF UNITED STATES

\begin{tabular}{|c|c|c|}
\hline I. & II. & III. \\
\hline Property group. & Number of families. & Aggregate wealth. \\
\hline $\begin{array}{l}\$ 50,000 \text { and over } \ldots \ldots \ldots \ldots \ldots \ldots \\
50,000 \text { to } \$ 5,000 \ldots \ldots \ldots \ldots \ldots \ldots \ldots \\
\text { Under } \$ 5,000 \ldots \ldots \ldots \ldots \ldots \ldots \ldots\end{array}$ & $\begin{array}{r}125,000 \\
1,375,000 \\
11,000,000\end{array}$ & $\begin{array}{r}\$ 33,000,000,000 \\
23,0 c 0,000,000 \\
9,000,000,000\end{array}$ \\
\hline & $12,500,000$ & $\$ 65, \infty 00,000, c 00$ \\
\hline
\end{tabular}

1 The Present Distribution of Wealth in the United States, p. 66. 
To sum up the reasoning so far: there are in the United States $12,500,000$ private families. Of these one-eighth, $I, 500,000$ ( $I, 562,500)$, own not less than $\$ 5,000$ worth of property each; $\frac{3^{6}}{409+3^{6}}$ or $\frac{36}{445}$ of these $I, 500,000$, or 125,000 $(\mathrm{I} 2 \mathrm{I}, 348)$ families are possessed of at least $\$ 50,000$. The average wealth of the thirty-six families is about $\$ 264,000$ $(\$ 8,794,663 \div 36=\$ 244,295)$, therefore, their total wealth is $\$ 264,000 \times 125,000$ or $\$ 33,000,000,000$. Similarly $\$ 23,000,000,000$ is obtained as the total wealth of the $\mathrm{I}, 375,000$ families worth from $\$ 5,000$ to $\$ 50,000$. The $\$ 9$,$000,000,000$ seems to be obtained by subtracting $\$ 56,000$,ooo,000 from $\$ 65,000,000,000$. $^{1}$

From the distribution of property, it is but a step to the distribution of incomes. "Nearly every family possessing $\$ 50,000$ worth of property receives an aggregate family income of $\$ 5,000$. Likewise, most families possessing over $\$ 5,000$ receive an aggregate income exceeding $\$ \mathrm{I}, 200 \ldots$ exceptions are practically offset by the families who receive the income specified without possessing the specified amount of property." Since, however, six per cent of Boston families then dwelt in houses the rental value of which would indicate an income not under $\$ 5,000$, and since in New York City there were " as many families with $\$ 5,000$ incomes as with $\$ 30,000$ property," it was concluded that about two hundred thousand households enjoyed such incomes. The incomes of the families worth less than $\$ 5,000$ are almost entirely from labor, and are reckoned as less than $\$ \mathrm{I}, 200$. Thus, with some observations as to the averages, it is concluded that the distribution of incomes in the United States is as follows :

${ }^{1}$ See Census, Wealth Debt, and Taxation, 1904, p. 29. 
TABLe VII

SPAHR'S ESTIMATE OF IISTRIBUTION OF INCOMES IN THE UNITED STATES ${ }^{2}$

\begin{tabular}{|c|c|c|c|c|c|}
\hline I. & II. & III. & IV. & v. & VI. \\
\hline \multirow{2}{*}{ Family income. } & \multirow{2}{*}{$\begin{array}{l}\text { Number of } \\
\text { tamulies. }\end{array}$} & \multirow{2}{*}{$\begin{array}{l}\text { Average income } \\
\text { trom labor. }\end{array}$} & \multicolumn{3}{|c|}{ Aggregate incoine. } \\
\hline & & & From labor. & From capital. & Total. \\
\hline$\$ 5,000$ and over & 200,000 & $\$ 3,500$ & $\$ 700, \infty 00, \infty 00$ & $\$ 2,410,000$, coo & $\&_{3}, 110, \infty 00,000$ \\
\hline$\$ 5,000$ to $\$ x, 200$ & $1,300,000$ & $x, 200$ & $x, 560,000,000$ & $1,330,000,000$ & $2,890,000,000$ \\
\hline \multirow[t]{2}{*}{ Under $\$ 1,200 .}$. & $11 x, \infty 00, \infty 00$ & 380 & $4,200,000,000$ & $600,000,000$ & $4,800,000,000$ \\
\hline & $12,500,000$ & $\$ 517^{2}$ & $\$ 6,460, \infty 00, \infty 00$ & $\$ 4,340,000,000$ & $\{10,800,000, \infty 00$ \\
\hline
\end{tabular}

These estimates of Dr. Spahr have been so widely quoted that they must be accorded some attention. In this brief compass it is impossible to do full justice to his argument, but surely the foregoing bald summary does not materially misrepresent his reasoning. Dr. Spahr's conclusion rests upon the assumption that, so far as the distribution of wealth is concerned, thirty-six counties in New York State are typical of the entire Union. The facts, if ever observed, may justify this premise, but they may not. Moreover, the postulate that the revenues of households worth less than $\$ 5,000$ never exceed $\$ \mathrm{I}, 200$, that the ownership of $\$ 5,000$ worth of property indicates an income of over $\$ 1,200$, and that possessions aggregating $\$ 50,000$ insure the opportunity of annually expending at least $\$ 5,000$, may be a very shrewd surmise, but is none the less a guess based upon the experience of one man. Resting thus on two rather questionable assumptions, the estimate of Dr. Spahr is not as satisfactory as it might be. ${ }^{3}$

${ }^{1}$ Spahr, op. cit., p. 128.

${ }^{2}$ Not in Spahr's table.

3 Every estimate involves assumptions, but some assumptions are much more venturesome than others. Both of Dr. Spahr's assumptions are rather bold. 
In the reasoning of Dr. Spahr, there are other points worthy of attention. For instance, it is not clear whether the estates of women are included in the tabulations, or whether any allowance should be made for property held in the wife's name. Again, it is probable that many farms are passed from father to son as gifts or sales, transfers which would not be recorded in probate returns. ${ }^{1}$ Professor MayoSmith raised the point that no account was taken of the ages of those who left estates: it may very well be true that many young men who died without wealth, were on the road to acquisition, and would have accumulated considerable property had they lived longer. Thus the argument tends to over-emphasize the concentration of wealth. Finally, Dr. Spahr's trust in "common observation" may not be quite justified, for it is so extremely easy to see "what is behind one's eyes." 2

It appears, then, that Dr. Spahr's conclusions cannot be accepted as a satisfactory description of the distribution of incomes. The estimate may be a close approximation to the facts, but the method is open to so many valid criticisms that without confirmation the results are inconclusive. With a larger base, perhaps, such as the French returns on "Successions and Donations" or the statistics of the English "Death Duties", analogous processes might be used to advantage in discussing the ownership of property, but even this data would hardly be a sound foundation for an estimate of the distribution of incomes.

${ }^{1}$ Census, 1900, vol. v, Agriculture, pt. i, pp. 1xxx, 1xxxix, col. 2.

2 " The writer has learned, and hopes to teach, that, upon matters coming within its field, the common observation of common people is more trustworthy than the statistical investigations of the most unprejudiced experts. Indeed, he has come to believe that social statistics are only trustworthy when they show to the world at large what common observation shows to those personally familiar with the conditions described." Spahr, op. cit., preface. 
Another attempt to formulate a general description of the distribution of compensation in the United States was made in I9r I, but the study was confined almost exclusively to an investigation of the earnings of factory operatives and railway employees. In his primary task of calling attention to the inadequacy of American wage statistics, Professor Nearing ${ }^{1}$ has been eminently successful, but in his method of attack, in utilizing the available material, he is not quite so fortunate. His argument may be briefly illustrated.

The classified wages of men in the factories of Massachusetts are presented in the following table.

TABLE VIII

CLASSIFIED WAGES, MALES TWENTY-ONE YEARS AND OVER, MASSACHUSETTS, $1908^{2}$

\begin{tabular}{|c|c|c|c|}
\hline I. & II. & III. & IV. \\
\hline $\begin{array}{c}\text { Classified } \\
\text { weekly earnings. }\end{array}$ & $\begin{array}{c}\text { Males } 2 \text { I years } \\
\text { and over. }\end{array}$ & Per cent. & $\begin{array}{c}\text { Cumulative }^{3} \\
\text { per cent. }\end{array}$ \\
\hline 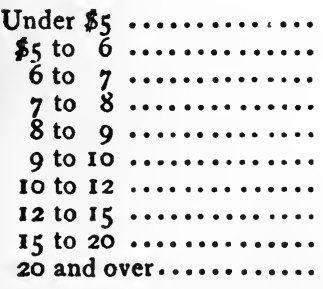 & $\begin{array}{r}5,049 \\
6,216 \\
13,584 \\
22,469 \\
31,472 \\
41,399 \\
61,632 \\
70,293 \\
69,996 \\
28,008\end{array}$ & $\begin{array}{r}1 \\
2 \\
4 \\
7 \\
9 \\
12 \\
17 \\
20 \\
20 \\
8\end{array}$ & $\begin{array}{r}1 \\
3 \\
7 \\
14 \\
23 \\
35 \\
52 \\
72 \\
92 \\
100\end{array}$ \\
\hline Totals $\ldots \ldots \ldots$. & 350,118 & 100 & \\
\hline
\end{tabular}

These wage rates, however, taken by themselves, are by

${ }^{1}$ Wages in the Uniled States, Igo8-rgro.

2Wages in the United States, p. 43; or 23d Ann. Rep't. Statistics of Manufactures, Mass., p. 82.

${ }^{3}$ Cumulative per cents not given by Nearing. 
no means representative of annual earnings, ${ }^{1}$ for allowances must be made for unemployment. The factories of the state reported 275 days worked out of 305 business days; in other words, these concerns were idle twelve per cent of the working time. Therefore, "the table of Classified Weekly Earnings, after being multiplied by 52 , must be reduced by 12 per cent, in order to represent an accurate average for the year. The stated weekly earnings, after subtracting I 2 per cent for unemployment, would give, in annual earnings, the percentages" in the following table:

\section{TABLE IX}

CUMULATIVE PERCENTAGES OF ADUIT MALES RECEIVING CLASSIFIED YEARLY EARNINGS (UNEMPLOYMENT DEDUCTED), ALI MASSACHCSETTS INDUSTRIES, $1908^{2}$

\begin{tabular}{|c|c|c|c|}
\hline $\begin{array}{c}\text { Classified yearly } \\
\text { earnings. }\end{array}$ & $\begin{array}{l}\text { Adult males, } \\
\text { per cent. }\end{array}$ & $\begin{array}{c}\text { Classified yearly } \\
\text { earnings. }\end{array}$ & $\begin{array}{l}\text { Adult males, } \\
\text { per cent. }\end{array}$ \\
\hline $\begin{array}{cr}\text { Under } & \$ 229 \ldots \ldots \ldots \\
\text { “ } & 275 \ldots \ldots \ldots \\
\text { “ } & 320 \ldots \ldots \ldots \\
\text { “ } & 366 \ldots \ldots \ldots \\
\text { “ } & 412 \ldots \ldots \ldots\end{array}$ & $\begin{array}{r}1 \\
2 \\
5 \\
12 \\
21\end{array}$ & 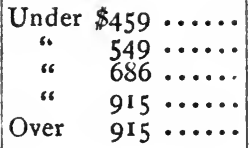 & $\begin{array}{r}35 \\
52 \\
72 \\
92 \\
8\end{array}$ \\
\hline
\end{tabular}

After corresponding tables have been presented for the four leading industries of the state the conclusion is reached

that not more than one adult male wage-earner in every twenty employed in the industries of Massachusetts receives, in annual earnings, for a normally prosperous year, more than \$I,000. On the other hand, more than one-third of all the adult males are paid wages under $\$ 500$; more than one-half receive wages under $\$ 600$; while nearly three-quarters receive less than $\$ 700$ annually. ${ }^{3}$

1 Nearing, op. cit., pp. 49, 51, 52.

${ }^{2}$ Ibid., p. 5I, table on p. 52. Compare Table VIII, column iv.

Ibid., p. 57. 
Tables, similarly altered, are drawn from the New Jersey and Kansas reports, the results showing a marked harmony. Additional certainty is given to the deductions by figures quoted from the special reports of the Bureau of Labor on the Strike at the Bethlehem Steel Works, and the Telephone Companies.

An exceedingly novel method is introduced in dealing with the wages of railway employees. The second, third, and fourth columns of the following table are taken from the Statistics of the Railways, ${ }^{1}$ the first and fifth being supplied by Professor Nearing.

From this table it is concluded that " in 1909, $5^{\text {I }}$ per cent of the million and a half railroad employees of the United States received less than $\$ 625$ per year ; ${ }^{2}$ that 93 per cent received less than $\$ 1,000$ per year, leaving 7 per cent who earned more than $\$ \mathrm{I}, 000$ annually."

1 1909, pp. 34, 40.

Nearing, op. cit., p. 176 . 
TABLE $\mathrm{X}$

DISTRIBUTION OF WAGES IN THE VARIOUS EMPLOYMENTS. RAILROADS OF THE UNITED STATES, $1909^{1}$

\begin{tabular}{|c|c|c|c|c|}
\hline I. & II. & III. & IV. & V. \\
\hline $\begin{array}{c}\text { Average } \\
\text { daily wages. }\end{array}$ & & Number. & $\begin{array}{c}\text { Average } \\
\text { daily wages. }\end{array}$ & Per cent. \\
\hline $\begin{array}{l}\text { Over } \$ 10 . . . \\
\$ 5 \text { to } 10 \ldots \\
4 \text { to } 5 \ldots \\
3 \text { to } 4 \ldots \\
2 \text { to } \quad 3 \ldots .\end{array}$ & 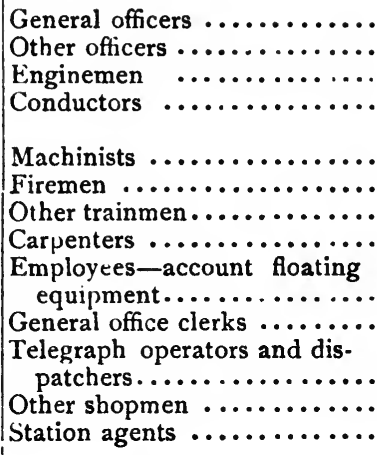 & $\begin{array}{r}5,492 \\
8,022 \\
57,077 \\
43,608 \\
48,237 \\
60,349 \\
114,760 \\
60,867 \\
8,758 \\
69,959 \\
39,115 \\
195,110 \\
36,519\end{array}$ & $\begin{array}{r}\$ 12.67 \\
6.40 \\
4.44 \\
3.81 \\
\\
2.98 \\
2.67 \\
2.59 \\
2.43 \\
\\
2.31 \\
2.31 \\
\\
2.30 \\
2.13 \\
2.08\end{array}$ & $\begin{array}{l}4 \\
3\end{array}$ \\
\hline I to & $\begin{array}{l}\text { Total } \$ 2 \text { to } \$ 3 \ldots \ldots \ldots \\
\text { All other employees and labor } \\
\text { ers } \ldots \ldots \ldots \ldots \ldots \ldots \\
\text { Section foremen } \ldots \ldots \ldots \ldots \\
\text { Other station men } \ldots \ldots \ldots \ldots \ldots \\
\text { Switch tenders, crossing tend } \\
\text { ers and watchmen } \ldots \ldots \ldots \ldots \\
\text { Other trackmen } \ldots \ldots \ldots \ldots \ldots \ldots\end{array}$ & $\begin{array}{r}633,674 \\
210,898 \\
41,859 \\
136,733 \\
44,698 \\
320,762\end{array}$ & $\begin{array}{r}1.98 \\
1.96 \\
1.82 \\
\\
1.73 \\
1.38\end{array}$ & 42 \\
\hline & $\begin{array}{l}\text { Total } \$ 1 \text { to } \$ 2 \ldots \ldots \ldots \\
\text { Total employees } \ldots \ldots \ldots\end{array}$ & $\frac{754,950}{1,502,823}$ & & $\frac{5^{1}}{100}$ \\
\hline
\end{tabular}

The most important of the tables presented by Professor Nearing are brought together for comparison in the last chapter of his book as follows:

1 Nearing, op. cit., p. 175. 
TABLE XI

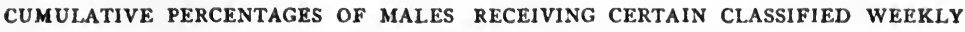
EARNINCS, COMPILED FROM CERTAIN REPORTS, 1908-1910'

\begin{tabular}{|c|c|c|c|c|c|c|c|}
\hline I. & II. & III. & IV. & v, & VI. & VII. & V11I. \\
\hline $\begin{array}{c}\text { Classified } \\
\text { weekly earnings. }\end{array}$ & 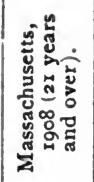 & 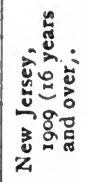 & 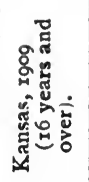 & 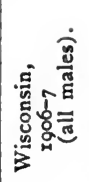 & 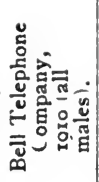 & 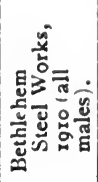 & 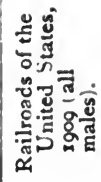 \\
\hline Under $\$ 8 \ldots \ldots \ldots \ldots \ldots$ & 12 & 18 & 8 & 12 & 5 & 8 & 22 \\
\hline Under $\$ 12 \ldots \ldots \ldots \ldots \ldots \ldots$ & 52 & 57 & 46 & 59 & 23 & 60 & $5^{I}$ \\
\hline Under $\$ 15 \ldots \ldots \ldots \ldots \ldots$ & 72 & 74 & 70 & 89 & 32 & 75 & $7^{8}$ \\
\hline Under $\$ 20 . . . . . . . . . \ldots \ldots$ & 92 & $9 x$ & $9 x$ & 98 & 80 & 92 & 92 \\
\hline$\$ 20$ and over ............... & 8 & 9 & 9 & 2 & 20 & 8 & 8 \\
\hline Total employed. ....... & 350,118 & 204,782 & 50,720 & 228,334 & 171,139 & 9,184 & $\mathrm{I}, 502,823$ \\
\hline
\end{tabular}

But in proceeding to annual earnings some allowance must be made for unemployment. This is done by the following reasoning: approximately "one-half of the adult males working in the industrial sections of the United States" are employed at a rate not over $\$ 12$ per week, or $\$ 600$ per year.

Three-quarters are paid less than $\$ 75^{\circ}$ annually and less than one-tenth earn $\$ 1,000$ a year. . . . These figures are not accurate, however, since they are all gross figures, including unemployment. They should be reduced by, perhaps, 20 per cent, varying with the year, the location and the industry. There may be no general agreement as to what reduction should be made,-but some reduction is obviously necessary. Making, therefore, a reduction of one-fifth, it appears that half of the

1 Nearing, op. cit., p. 210. The total at the foot of column vi should be 15,326. Investigation of Telephone Companies, p. 294. A similar summary is made for the wages of women. 
adult males of the United States are earning less than $\$ 500$ a year; that three-quarters of them are earning less than $\$ 600$ annually; that nine-tenths are receiving less than $\$ 800$ a year; while less than ten per cent receive more than that figure.

This proportion applies to the United States " east of the Rockies and north of the Mason and Dixon Line". ${ }^{1}$

These interesting conclusions of Professor Nearing have received so much publicity that it is necessary to consider the method by which they were reached. In the first place, although all the data, which serve as a base for the final estimate of annual wages of males, relate to the limited field of manufactures, railroading, and telephoning, the natural inference of the reader is that the conclusions apply to " the annual earnings of adult males (and females) employed east of the Rockies and north of the Mason and Dixon Line." In just what sense this inference is altered by the earlier allusion to "the industrial sections of the United States" can hardly be determined. Does the estimate, for instance, include all men employed at all tasks in urban communities, or only those who are engaged in what are generally known as "industrial pursuits"-manufactures, trade and transportation? Doubtless the latter is the correct interpretation, but it might advantageously be indicated more clearly in Professor Nearing's closing section.

It is the deduction of a certain per cent for unemployment,

1 Nearing, $o p$. cit., pp. 213, 2r4. Perhaps it would be only just to add Professor Nearing's closing words: "It is not important that the reported wages be reduced by one-fifth. The available unemployment data indicates that such a reduction is an approximately correct one; if, however, later studies show this estimate of unemployment to be excessive or inadequate, a corresponding alteration will be made in the summary of wages, but until such a study appears, the answer to the question, "What are wages?' is contained in the above summary." The summary in Professor Nearing's book includes parallel deductions concerning the wages of adult females. 
however, that particularly challenges attention. This process has been explained at length in connection with the general figures for Massachusetts, and later summarized in Professor Nearing's own words. Nine-tenths of the adult male factory operatives are employed at wage rates less than $\$ 20$ per week; the average idleness is one-fifth of the working time; therefore, ninety per cent of these operatives earn less than $\$ 800$ per annum. Such reasoning entirely disregards the actual distribution of unemployment. About half of the workers are unemployed for a week or more during the course of a normal year; of this half probably forty per cent are out of work at least ten weeks; thus approximately a fifth of the American factory or industrial people are idle as much as one-fifth of their time. This is not a dogmatic statement but is probably not far from the truth. ${ }^{1}$ It is then preposterous to argue that, since the maximum earning power of nine-tenths of the adult males engaged in manufacturing is $\$ \mathrm{I}, 04 \mathrm{O}$, and since the average loss of working time is twenty per cent, all these ninety per cent earn less than $\$ 800(\$ 832)$. Possibly some of these men worked continuously, perhaps a half did not lose more than two weeks or at most a month. Nearly sixty per cent of the 24,402 heads of families studied by the Bureau of Labor in I90 I were idle less than two weeks if at all; 1,660 of the $2,55^{6}$ female department store employees investigated in Illinois in 1908, it will be remembered, figured in fifty weekly pay rolls; 32 blacking factories in Massachusetts were busy in 1908 an average of 305.22 days, six billiard table works, 306.33 days; six cotton-waste companies, 301.95 days; nine engraving and die-sinking establishments, 304.67 days, and, by way of contrast, 49 brick and tile con-

${ }^{1}$ See the Eighteenth Annual Report of the Commissioner of Labor, pp. 288, 289; also Twelfth Census of the United States, 1900, Special Report on Occupations, pp. ccxxvi-ccxxxv. 
cerns averaged but 148.46 busy days. ${ }^{1}$ The burden of unemployment is, therefore, very unevenly distributed among industries and among individuals, and cannot be dealt with by a simple reduction of maximum earnings. Doubtless. some of those men employed at $\$ 20$ per week earned less than $\$ 800$ in the course of the year, but it is inconceivable that all of them were idle twelve weeks. What the fraction was, none can say. Not to quarrel, then, with Professor Nearing's belief that twenty per cent of industrial working time is lost, his method of deducting for unemployment is misleading.

Another question of method arises in connection with the treatment of the earnings of railroad employees. For instance, in Professor Nearing's table, switch-tenders, crossing-tenders, and watchmen to the number of 44,698 are included in one group with average per diem wages of $\$ 1.73$. All these men, he reasons, receive daily between one and two dollars, and, therefore, earn not more than $\$ 600$, or, allowing for unemployment, $\$ 500$ per year. Now as a matter of fact, of the I2O switchmen who were listed in the Bureau of Labor investigation in I9OI, sixty per cent earned more than $\$ 600$ and thirty-five per cent more than $\$ 700$. Again, the author lists all firemen as having labor incomes less than $\$ \mathrm{I}, 000$, yet the official study showed seven per cent of these men receiving more than that sum. Similarly, nearly forty per cent of the engineers, whom Professor Nearing classes as enjoying incomes over $\$ \mathrm{I}, 000$, actually received less. ${ }^{\text {. }}$ These concrete illustrations demonstrate better than argument the fallacy of maintaining that, if the average wages

${ }^{1}$ There were 307 business days in 1908. Mass. Statistics of Manufactures, 1908, pp. I21 et seq.; Eighteenth Annual Report of the Commissioner of Labor, p. 288; Biennial Report, Bureau of Labor Statistics, Illinois, I908, pp. 426, 445.

2 Eighteenth Annual Report of the Commissioner of Labor, p. 283. 
of a given group of men is a certain amount, each individual in that category earns less than, or more than, some other specified sum. There appears no reason for assuming that the errors thus committed are counterbalancing, and, therefore, conclusions thus derived fail to carry conviction.

These two flaws in the method make it impossible to accept Professor Nearing's answer to the question, "What are Wages?" On the other hand, these adverse criticisms of his work serve but to confirm his main contention-that the development of wage statistics in the United States is extremely unsatisfactory.

Having thus briefly considered the two studies of distribution of incomes and of earnings in the United States which have a claim to scientific accuracy, it is well worth while to compare their conclusions with the results of European statistical compilations. For the year 1892, Dr. Spahr found that eighty-eight per cent of the twelve and a half million American families had incomes of $\$ 1,200$ or less. According to Professor Nearing, in the years about I908-I9Io, ninetenths of the adult males engaged in industry east of the Rocky Mountains and north of the Mason and Dixon Line earned annually no more than $\$ 800$, and the same proportion of women received in wages less than $\$ 500$. Suppose that, in this group, the highest paid men marry the best remunerated women; even then, the annual earning power of ninety per cent of the couples dependent on industry would be under $\$ 1,300$. Of course this supposition is purely fanciful; it disregards the contributions of children, and the possible intermarriages between men and women on different wage levels; but it seems to be the only way of comparing the results of the two American studies. In fact the conclusions are not parallel, for Spahr treated incomes of families in the United States as a whole, while Nearing devoted his attention to the earnings of individuals in a 
limited number of occupations in a definite fraction of the country.

On the other hand, there is a surprising coincidence between the figures of Dr. Spahr, and the conclusions of Professor Paul Leroy-Beaulieu. Basing his calculations upon the rentals of lodgings in Paris, the learned French economist found that, in 1896 , probably 89.02 per cent of the families in that city were living on less than 7,000 francs $(\$ \mathrm{I}, 35 \mathrm{I})$ a year and $\mathrm{I} .86$ per cent enjoyed incomes of not less than 32,000 francs $(\$ 6,176)$. These results are remarkably similar to those of Dr. Spahr, who estimated eighty-eight per cent of American families as having, in I892, revenues less than $\$ \mathrm{I}, 200$, and one and six-tenths per cent over $\$ 5,000$. As Professor Leroy-Beaulieu remarks, the proportion of high incomes is probably larger in Paris than in France as a whole; France, moreover, with the exception of Australia and the United Kingdom, is probably the richest country in the world. ${ }^{1}$ The conclusions, therefore, are in a strict sense incomparable one applying to a great city, the other to a nation, yet the similarity is worth noting. ${ }^{2}$

In this connection the Prussian fiscal returns are also interesting. In 1905 , for instance, out of a total population of over thirty-six million, I,88 I,49I were entirely exempt from the assessment, and $20,483,263$, or 56.48 per cent of the individual inhabitants, were attached to families no member of which enjoyed an income of 900 marks (\$214.$20)$. Over ninety per cent of all the residents belonged to

\section{${ }^{1}$ Census, Wealth, Debt, and Taxation, 1904, p. 35.}

2 Incomes were found by multiplying by ten rents over 7,000 fr.; by eight rents from $2,500 \mathrm{fr}$. to $6,999 \mathrm{fr}$.; by seven rents below $2,500 \mathrm{fr}$. Paul Leroy-Beaulieu, Essai sur la répartition des richesses, fourth edition, 1896, p. 563 . 
families no member of which had an income of 3,000 marks (\$714). Suppose that each of the households in the class first mentioned had three members gainfully employed at the maximum of tax exemption (899 M.), there would still be approximately fifty-six per cent of the families in Prussia living on less than 2,700 M. (\$643) per year. Is this supposition impossible? Are there many families in Prussia with four, five, and more providers? Possibly; yet for an industrial family in the United States to have a total revenue double that of its largest wage-earner is quite unusual, and a working-class household enjoying an income three times the compensation of its main supporter is a rarity indeed. In view of these considerations, and of the facts shown in Table XII, it is entirely safe to conclude that more than half, probably more than six-tenths, of the

Note 2, p. 80, continued:

RENTS AND INCOMES IN PARIS, JANUARY I, 1896

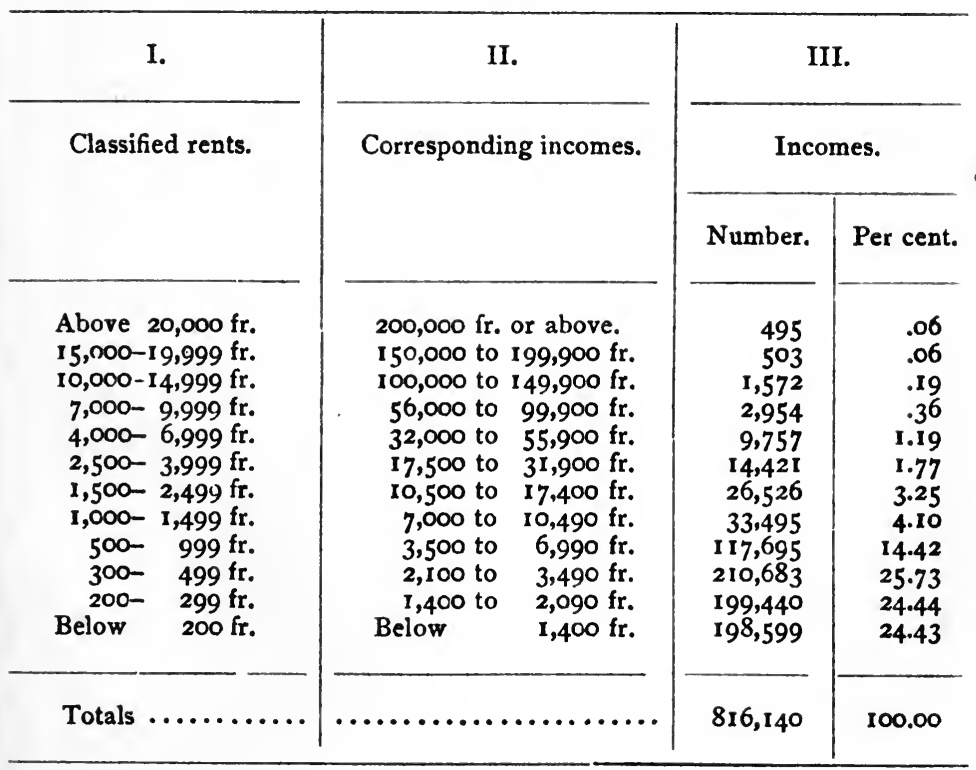


TABLE XII

INCOME TAXES-PRUSSIA, $1905^{1}$

\begin{tabular}{|c|c|c|c|c|}
\hline \multirow[b]{2}{*}{ Class of incomes. } & \multirow[b]{2}{*}{ Taxpayers. } & \multirow[b]{2}{*}{$\begin{array}{l}\text { Members } \\
\text { of } \\
\text { families. }\end{array}$} & \multicolumn{2}{|c|}{ Per cent of } \\
\hline & & & $\begin{array}{c}\text { Tax- } \\
\text { payers. }\end{array}$ & $\begin{array}{c}\text { Members } \\
\text { of } \\
\text { families. }\end{array}$ \\
\hline 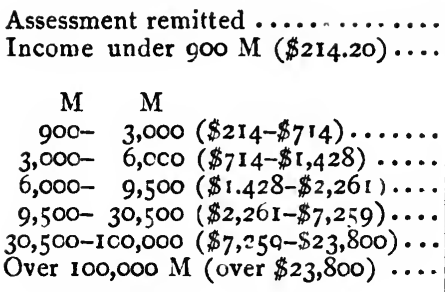 & $\begin{array}{r}\text { (not taxed on } \\
\text { income) } \ldots . \\
3,889,171 \\
326,921 \\
86,340 \\
70,943 \\
14,374 \\
2,859\end{array}$ & $\begin{array}{r}1,881,491 \\
20,483,263 \\
12,262,036 \\
1,083,802 \\
277,123 \\
227,251 \\
45,454 \\
9,019\end{array}$ & $\mid$\begin{tabular}{r|}
$\cdots \cdots$ \\
$\cdots \cdots$ \\
88.58 \\
7.44 \\
1.96 \\
1.62 \\
.33 \\
.07
\end{tabular} & $\begin{array}{r}5.19 \\
56.48 \\
33.81 \\
2.99 \\
.76 \\
.63 \\
.12 \\
.02\end{array}$ \\
\hline 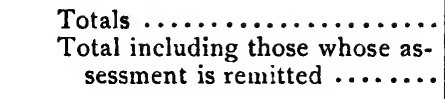 & $\begin{array}{c}4,390,608 \\
\ldots \ldots \ldots\end{array}$ & $\begin{array}{l}34,387,948 \\
36,269,439\end{array}$ & 100.00 & 100.00 \\
\hline
\end{tabular}

families of Prussia do not enjoy annual incomes of $2,700 \mathrm{M}$. $(\$ 643)$. That eighty-eight per cent of the persons who actually pay the income tax in Prussia should be assessed on no more than 3,000 M. (\$7I4), indicates that wages in Germany must be lower than those of the industrial workingmen of the United States of whom ninety per cent, according to Professor Nearing earn less than $\$ 800$ per annum. In discussing these French and German statistics, it must not be forgotten that prices vary from country to country. Even were the comparative costs of living known, a true contrast between the welfare of the inhabitants of different states could not be made without taking account of

1 Jahrbücher für National Oekonomie und Statistik, Volkswirtschaftliche Chronik, 1906, vol. 87, pp. 489, 491. 
the psychological differences of their people. The question of national well-being is extremely complicated.

Because of the separate assessment of (A) returns from the ownership of lands and houses, (B) revenues from the occupation of land, (C) annuities, dividends, and interest payable in the United Kingdom on government securities, (D) annual profits arising to persons residing in the United Kingdom from any kind of property wheresoever situated, or from any profession, trade, employment, or vocation wheresoever carried on; on annual profits arising to persons not resident in the United Kingdom from property wheresoever situated, or from any profession, trade, employment, or vocation exercised in the United Kingdom; and on interest of money, annuities, and other annual profits and gains, and (E) on incomes derived from public offices, or employments of profit, and on annuities, pensions, or stipends payable by her majesty, or out of the public revenue of the United Kingdom:-because personal receipts falling in these different schedules have been separately assessed, the British income tax supplies no answer to the question as to the distribution of incomes. ${ }^{1} \quad$ Schedules D and E include what the English know as "business and professional" incomes. In the fiscal year 1906-1907, there were 904,888 assessments of individuals in these two classes. The population of the Kingdom was about forty-four million, or, roughly, nine million families. Can it then be held that about one-tenth of the British households enjoy incomes of $£_{1} 60$ or more? The answer depends on (I) the number of individuals figuring in both schedules $\mathrm{D}$ and $\mathrm{E},(2)$ the number of persons assessed in the first three classes but not in the last two, (3) the number of persons enjoying revenues from several sources, aggregating over $\mathfrak{f I}_{\mathrm{f}} \mathrm{o}$ but each 
less than that sum, and (4) the extent of evasions. There is also, now, a "Super-Tax" on incomes in excess of $\mathfrak{1}_{5}$,000. Up to March 3 I, I9I I, I0,287 such incomes were reported, and more returns were being received. The Commissioners of Inland Revenue would hazard nothing more than that there were over 10,600 individuals enjoying incomes of at least $\mathfrak{f}_{5}, 000 .^{1}$ It is, therefore, unsafe to speculate upon the interpretation of these British income-tax returns.

\section{TABLE XIII}

INCOME TAX-UNITED KINGDOM, 1909-10²

(Part of Returns of Schedules D and E. The numbers are those of "Assessments," not of Taxpayers)

\begin{tabular}{|c|c|c|c|c|c|c|c|c|c|}
\hline \multicolumn{5}{|c|}{ I. } & II. & III. & IV. & v. & VI. \\
\hline \multicolumn{5}{|c|}{ Income } & 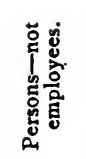 & 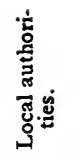 & 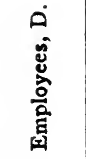 & 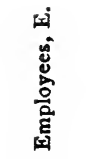 & 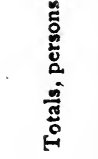 \\
\hline \multicolumn{5}{|c|}{ Not exceeding $€ 160$ but not exempt........... } & 187,774 & $7,53^{8}$ & 18,650 & 186,212 & $400, \mathbf{1 7 4}$ \\
\hline Exceeding & $6 \times 60=$ & id no & exceeding & 6200. & 96,022 & 404 & 37,629 & 100,264 & 234,319 \\
\hline “ & 200 & “ & “ & $500 .$. & $x \times 0,643$ & $\mathrm{I}, 224$ & 49,776 & 172,247 & 333,890 \\
\hline “ & 500 & “ & “ & $x, \infty 00 .$. & 20,956 & 673 & 4,014 & 28,540 & 54,283 \\
\hline “ & 1,000 & “ & “ & 5,000 . & $10, x_{3} 8$ & $\mathbf{x , x 1 6}$ & 753 & $7,30 x$ & $x 9,308$ \\
\hline “ & $£ 5,000$ & ... & (............ & ...... & 805 & $6 \times 5$ & 3 & 167 & $\mathrm{x}, 590$ \\
\hline Total & ls & & & ... & $426,33^{8}$ & 11,570 & 110,825 & $494,73^{x}$ & $x, 043,464$ \\
\hline
\end{tabular}

'Report of the Commissioners of His Majesty's Inland Revenue for the year ended 3Ist March, 19II, p. 99.

${ }^{2}$ Fifty-fourth Report of the Commissioners of Inland Revenue for the year ended 3Ist March, I9II, p. I32. The Royal Statistical Society conducted an investigation in I9lo to determine the distributions of incomes under $t 160$ in the salaried classes. The numbers earning above 
More significant, perhaps, for the present purpose, than the income tax, is the tax on the rental value of inhabited houses.

This table shows that about eighty per cent of the families of England and Scotland live in houses of an annual rental value under $£ 20$ or $\$ 97.33$. Just what are the ratios of rents to incomes in Great Britain, is doubtful, but the recent report of the British Board of Trade showed that money wages in the United States are to money wages in England and Wales as 230 is to 100, and that rents in American cities are to rents in England and Wales as 207 is to Ioo. The fraction of the Englishman's income which goes for housing, therefore, cannot be much different from that of the American's. ${ }^{1}$ Probably few families spend less

and below $£ i 60$, and the percent of those earning less than $£ 160$ in each minor group, is shown in the following table. Jour. Royal Stat. Soc., lxxiv, p. 66.

SALARIED EMPLOYEES-MEN AND LADS

\begin{tabular}{|c|c|c|c|c|c|c|c|c|c|}
\hline Profession & 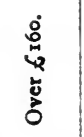 & 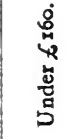 & 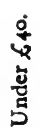 & 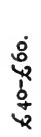 & 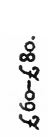 & 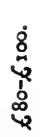 & 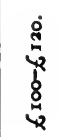 & 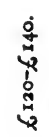 & 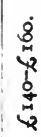 \\
\hline 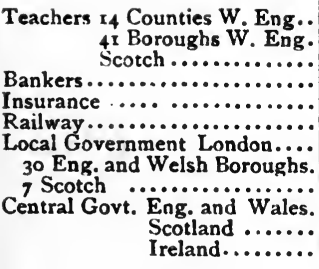 & $\begin{array}{l}7,000 \\
\cdots \cdots \\
1,500 \\
5,744 \\
1,619 \\
2,440 \\
8,000 \\
36,000\end{array}$ & $\begin{array}{l}30,000 \\
\cdots \cdots \\
4,500 \\
8,490 \\
1,585 \\
26,874 \\
26,000 \\
26,000\end{array}$ & $\begin{array}{r}13 \\
13 \\
2 \\
14 \\
21 \\
10 \\
0 \\
13 \\
9 \\
8 \\
8 \\
10\end{array}$ & $\begin{array}{r}6 \\
5 \\
2 \\
13 \\
18 \\
13 \\
1 \\
9 \\
8 \\
14 \\
15 \\
13\end{array}$ & $\begin{array}{r}13 \\
9 \\
4 \\
13 \\
12 \\
26 \\
1 \\
16 \\
13 \\
14 \\
15 \\
16\end{array}$ & $\begin{array}{l}12 \\
16 \\
16 \\
14 \\
12 \\
22 \\
17 \\
18 \\
17 \\
17 \\
23 \\
21\end{array}$ & $\begin{array}{l}22 \\
18 \\
25 \\
14 \\
15 \\
15 \\
28 \\
19 \\
24 \\
17 \\
17 \\
18\end{array}$ & $\begin{array}{r}22 \\
17 \\
24 \\
14 \\
10 \\
8 \\
23 \\
13 \\
15 \\
17 \\
16 \\
14\end{array}$ & $\begin{array}{r}12 \\
22 \\
27 \\
18 \\
12 \\
6 \\
6 \\
30 \\
12 \\
14 \\
13 \\
6 \\
8\end{array}$ \\
\hline Average............... & $\cdots \cdots$ & & 14 & 12 & 18 & 18 & $x 6$ & 12 & 10 \\
\hline
\end{tabular}

${ }^{1}$ Bulletin of the Bureau of Labor, no. 93, p. 555. According to these ratios, the proportion of income spent for rent averages one-tenth more in England than in America. That is, if the American spends 20 per cent of his income for housing, the Englishman spends 22 per cent. 
TABLE XIV

RENTAL VALUES OF HUUSES IN ENGLAND AND SCOTLAND ${ }^{\prime}$

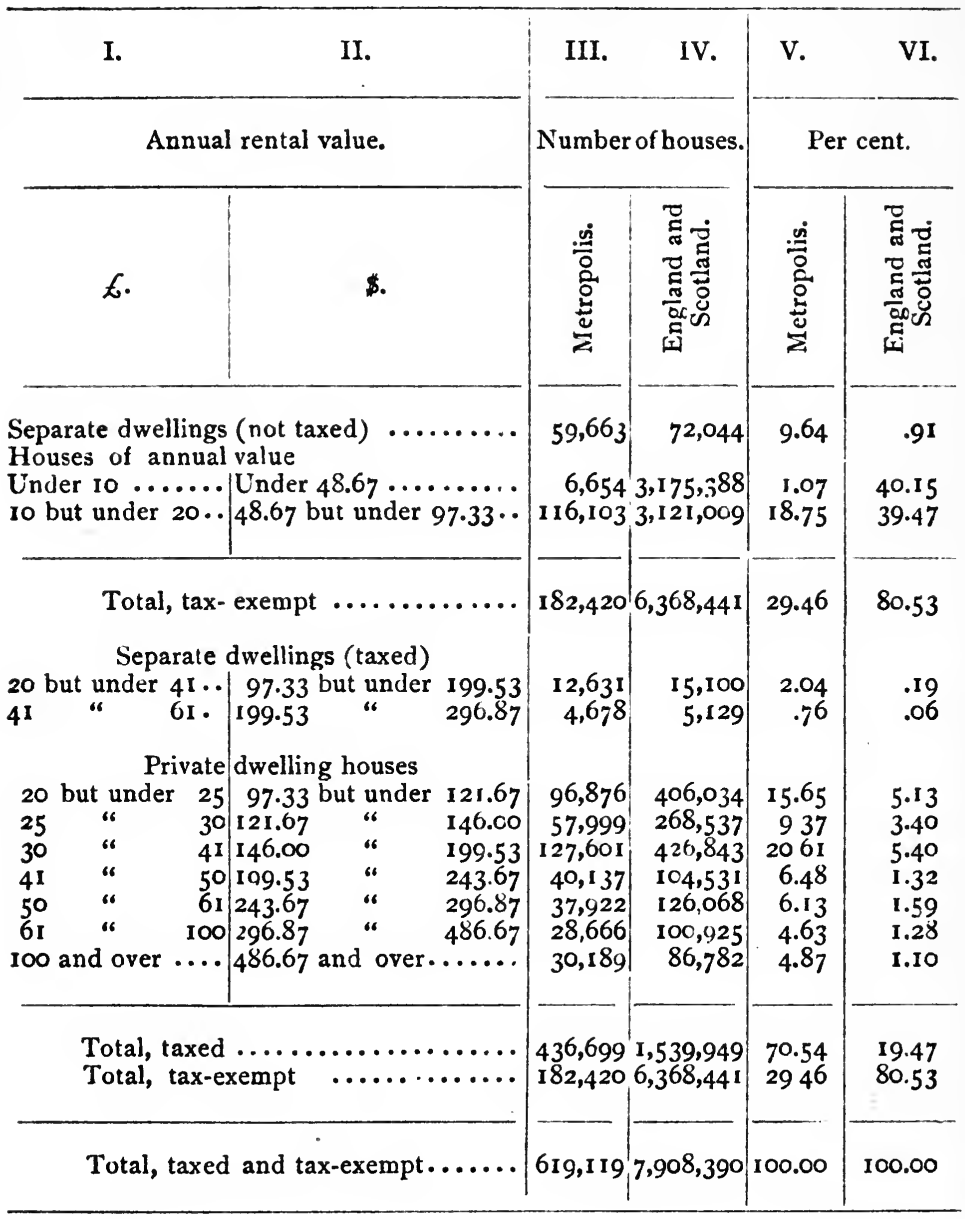

1 Compiled from material on pp. 80, 88, and 97 of the Fifty-fourth Report of the Commissioners of His Majesty's Inland Revenue, for the year ended March 3Ist, I9II. The figures relate to the fiscal year Igog1910, and include dwellings and farm laborers' houses, but omit residential shops, lodging-houses, hotels, public houses, and coffee-houses, some of which should be included for a strictly inclusive presentation. 
than a seventh of their revenue for shelter. On this supposition eighty per cent of the English families have incomes under fr$_{40}$ (\$68I), ninety per cent, under f2ro $^{2}$ $(\$ 1,022) .^{1}$

On the strength of the preceding survey, the following conclusions may be confidently advanced:

I. The best attempts to estimate the distribution of incomes in the United States have been inconclusive.

2. There is a striking similarity between Spahr's description of the distribution of incomes in the United States, and Leroy-Beaulieu's figures for Paris.

3. The Prussian and British income taxes are not a satisfactory guide to the distribution of revenues in those countries, although for incomes over 900 M., the Prussian impost, ignoring the possibility of extensive evasion, is, so far as individuals are concerned, an excellent criterion.

4. The available data certainly indicate that a large number of families in each of the four greatest nations must exist on very small incomes.

5. As far as money incomes are concerned, Americans seem to be somewhat better off than Germans, French, or English, but, in view of the differences in cost of living and in mentality, it is unsafe to attempt to compare "welfare" in the different countries.

6. Professor Nearing has shown that to form the base of a general estimate of the distribution of incomes from labor in the United States, American statistics are inadequate.

1 The use of exact ratios such as may be found in the Eighteenth Annual Report of the Commissioner of Labor, pp. 582, 585; or Chapin, Standard of Living, p. 70, would give a misleading impression of precision. The value of classified rents as a guide to the distribution of incomes will be discussed later, Chapter IX. 


\section{CHAPTER VI}

\section{Statistics of the Distribution of Wages}

IN the preceding chapters it has developed that data for an accurate description of the distribution of incomes or of earnings in the United States do not exist, and that the two most ambitious and scientific estimates have been unsatisfactory. It remains to consider just what inferences the published statistics warrant.

The first question to demand attention is, "Who support the families of the United States?" In I900 there were I 5,963,965 private families. There were $29,073,233$ individuals, ten years of age or over, engaged in gainful occupations, of whom not more than I3,956,3I4 were married men; 9,797,522 were single males, and 5,319,397 were females. Therefore, there were at least $2,007,65 \mathrm{I}$ more families than there were wage-earning married men; that is, two million households were without what is generally considered the natural support and protector. ${ }^{1}$ The average number of gainfully-employed persons per family was I.82. In these figures, however, there is no hint of the number of men who bear unaided the financial burden of maintaining their households. A first approximation may be obtained as follows: Of the 25,440 families investigated by the Bureau of Labor in I901, 95.92 per cent were to some extent dependent on the husband for support. To the total household income the wife contributed in 8.54 per cent, children in 22.19 per cent, boarders and lodgers in 23.26 
per cent, and other resources in 14.35 per cent of the cases.' The sum of these percents is 68.34 , but 4.08 per cent of these families had no aid whatsoever from the father, leaving a maximum of 64.26 per cent of the households having income from two sources. In other words, if the sources of income had been distributed so as to give as many families as possible a revenue from more than one contributor, the expenses of 35.74 per cent would have been entirely defrayed by the father. In $1890,4,3$ I 9 households dependent upon the cotton, woolen, and glass industries were studied by the same office. It was found that in the cotton community 23. I per cent of the families represented were supported solely by the husbands' exertions, 49.6 per cent in the woolen, and 64.I in the glass, or 40.6 per cent in all. ${ }^{2}$ It should be noted that these industries employ a large proportion of women and children. Dr. Chapin found that 46.8 per cent of the households with incomes of from $\$ 600$ to $\$ \mathrm{r}, 099$ in New York City, which came under his observation, were entirely maintained by the father. ${ }^{3}$ In view of these facts is it not safe to conclude that certainly fourtenths, probably forty-five per cent of industrial families, are completely dependent on the father-husband?

It is not necessary to leave the question here, however, for there exist some data which throw light on the problem. In compiling Table XV, the original budgets of $39 \mathrm{r}$ families, prepared in 1907 for the Charity Organization Society and described in Dr. Chapin's Standard of Living in New York City, were used. Table XVI is based upon the individual accounts of industrial families printed in the 1888 report of the New Jersey Bureau of Statistics of Labor

1 Eighteenth Annual Report of the Commissioner of Labor, p. 362.

Streightoff, Standard of Living, p. 59.

'Chapin, Standard of Living, p. 55. 


\begin{tabular}{|c|c|c|c|c|c|}
\hline & $\vec{x}_{x}$ & & 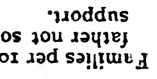 & 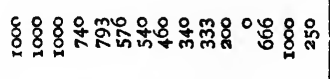 & 8 \\
\hline & $\underset{x}{Z}$ & Ë & '[E]OLL & 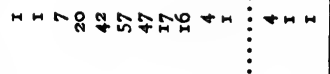 & สิ \\
\hline & 爻 & $\stackrel{g}{\tilde{E}}$ & 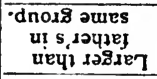 & & 4 \\
\hline$\hat{\circ}$ & $\dot{\vec{x}}$ & & 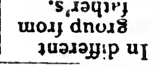 & HMNO & 吕 \\
\hline : & $\dot{x}$ & & ${ }^{2}{ }^{2} 30 \mathrm{~L}$ & HAN क्ष & ప్ \\
\hline 3 & $\underset{x}{x}$ & & $\cdot 66 I^{6} z-\infty I^{\prime} z \$$ & & w \\
\hline$E$ & 3 & & $\cdot 660^{\prime} z-\infty 00^{\prime} z \$$ & & $\omega$ \\
\hline :్ల & 5 & & $\cdot 666^{\prime} x-\infty 6^{\prime} \times \$$ & & $\vdots$ \\
\hline 2 & $\stackrel{1}{>}$ & & $668^{6} x-008^{6} x \$$ & & $\vdots$ \\
\hline m & 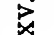 & & $\cdot 66 L^{\prime} I-\infty L^{\prime} x \$$ & $: \vdots$ & $\omega$ \\
\hline 武 & $z$ & & . $669^{\prime} x-\infty 0^{4} x \$$ & & m \\
\hline 贸 & 泉 & $\dot{y}$ & .665'I-0د5'x\$ & & 0 \\
\hline 惫 & $\vec{z}$ & : & $66 b^{\prime} x-00 t^{\prime} x \$$ & & N \\
\hline 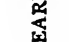 & $\dot{\vec{x}}$ & 臨 & $66 \varepsilon^{\prime} 1-00 \varepsilon^{\prime} 1 \$$ & $\vdots$ & $\infty$ \\
\hline 是 & $\dot{x}$ & & $\cdot 66 z^{\prime} I-00 z^{\prime} x \$$ & $::: H$ & $\infty$ \\
\hline 록 & $\underset{x}{x}$ & & .661'x $\infty x^{\prime} x \$$ & & 욤 \\
\hline ర్ & 봉 & & $.660^{\prime} I-\infty 00^{\prime} I \$$ & & 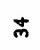 \\
\hline 㝵 & $\stackrel{5}{5}$ & & $.666 \cdot 006 \$$ & H & ભ \\
\hline Fin & $\dot{5}$ & & $.668008 \$$ & $\vdots \vdots$ MUON & $\mathfrak{N}$ \\
\hline $\mathbb{5}$ & $>$ & & $\cdot 66 L-00 \angle \$$ & $\vdots \vdots$ N nag $5 \vdots \vdots \vdots$ & ஃ \\
\hline & $\gtrsim$ & & $.669-009 \$$ & 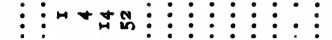 & ה \\
\hline & $\Xi$ & & $\cdot 665 \infty \$$ & 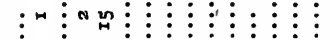 & $\underset{\sim}{\infty}$ \\
\hline & $\stackrel{-}{\sharp}$ & & $.66 t-00 t \$$ & $\vdots \vdots$ ! $\vdots \vdots \vdots \vdots \vdots \vdots \vdots \vdots$ & $\infty$ \\
\hline & $-i$ & & 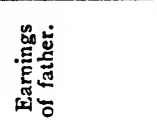 & 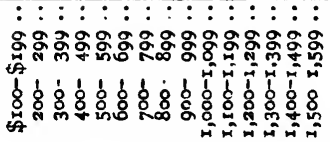 & 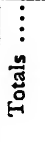 \\
\hline
\end{tabular}




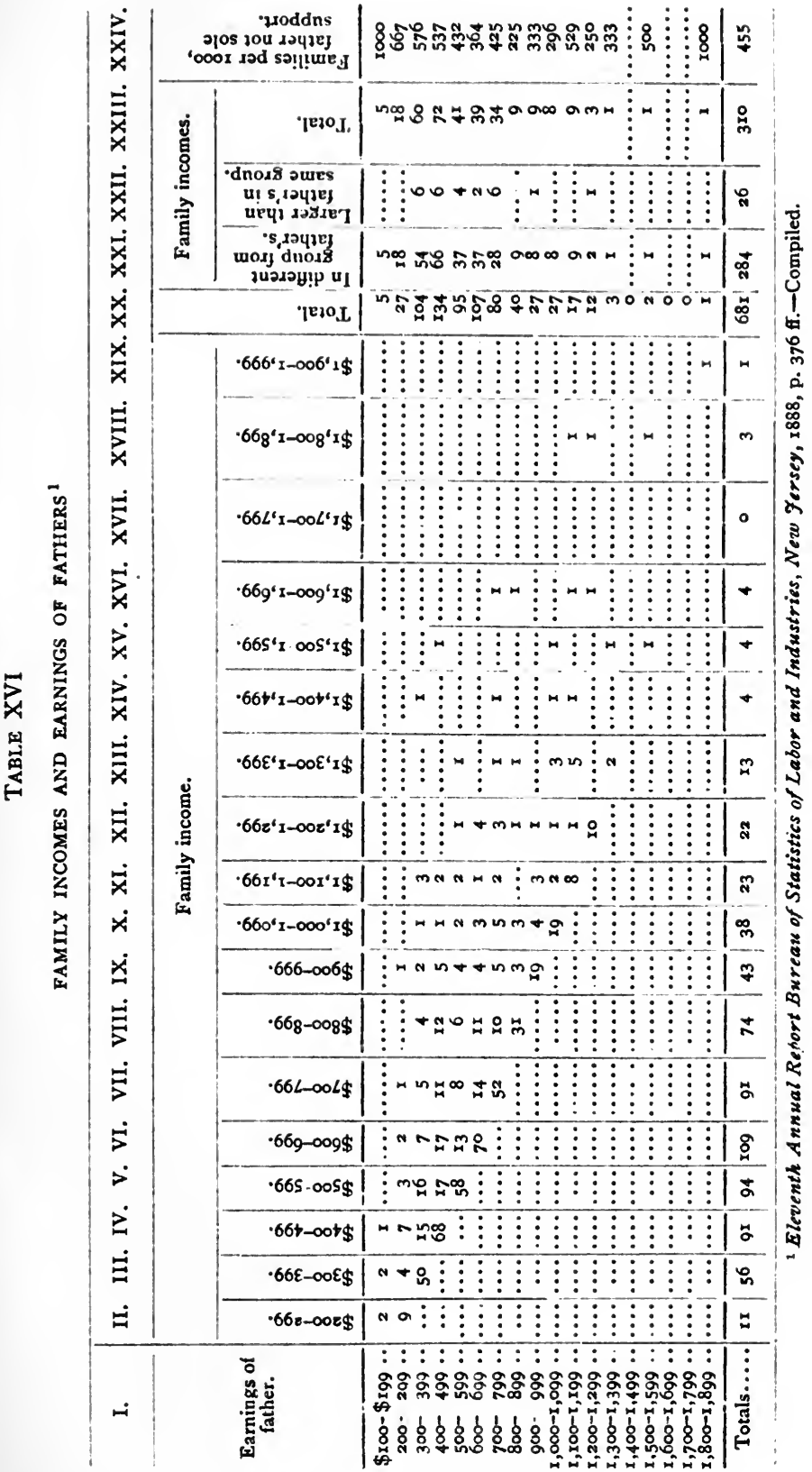


and Industries. Since the number of families considered is in each case so small, it is not surprising to find irregularity. Nevertheless each table reveals a definite tendency for the proportion of families dependent solely upon the father to increase as his wages become larger. In the metropolis 44.0 per cent of all the households, and in New Jersey 54.5 per cent, were supported entirely by the exertion of the husband. The columns numbered IV and $V$ in Table XVII show very conclusively that the greater the earning capacity of the father the less is the probability that his contribution will have to be supplemented from other sources. The apparent inconsistency between these two columns is probably due to the lapse of time, the rise in general prices, the difference in locality, and perhaps to other causes.

The New Jersey figures show that approximately fiftyfive per cent of the households having husbands are entirely supported by them; it will be remembered that the number of private families is about one-seventh larger than the number of married men. If that ratio held in New Jersey in I888, then, roughly, forty-eight per cent of the households were dependent on fathers. ${ }^{1}$ In New York City, in 1907, the ratio would have been $38.3^{\mathrm{I}}$ per cent. It seems, therefore, safe to conclude that between four and five-tenths of the industrial families of the United States derive their entire money income from the labor of the father-husband. ${ }^{2}$

$168 \mathrm{I} \times \frac{8}{7}=778: 68 \mathrm{I}-3 \mathrm{IO}=37 \mathrm{I}: 37 \mathrm{I}$ is $47.69 \%$ of 778 .

2 It should be noted that after the earnings of the father reach a certain point where saving is possible, the probability that he will invest begins to increase. The larger his labor income, the more able he is to set aside. So, if columns IV and V of Table XVII were continued, the values would presently begin to increase, and would doubtless ultimately reach and remain at 1.000. In other words, 100 per cent of the men with very high earnings, probably, have supplemental incomes from some form of capital. 


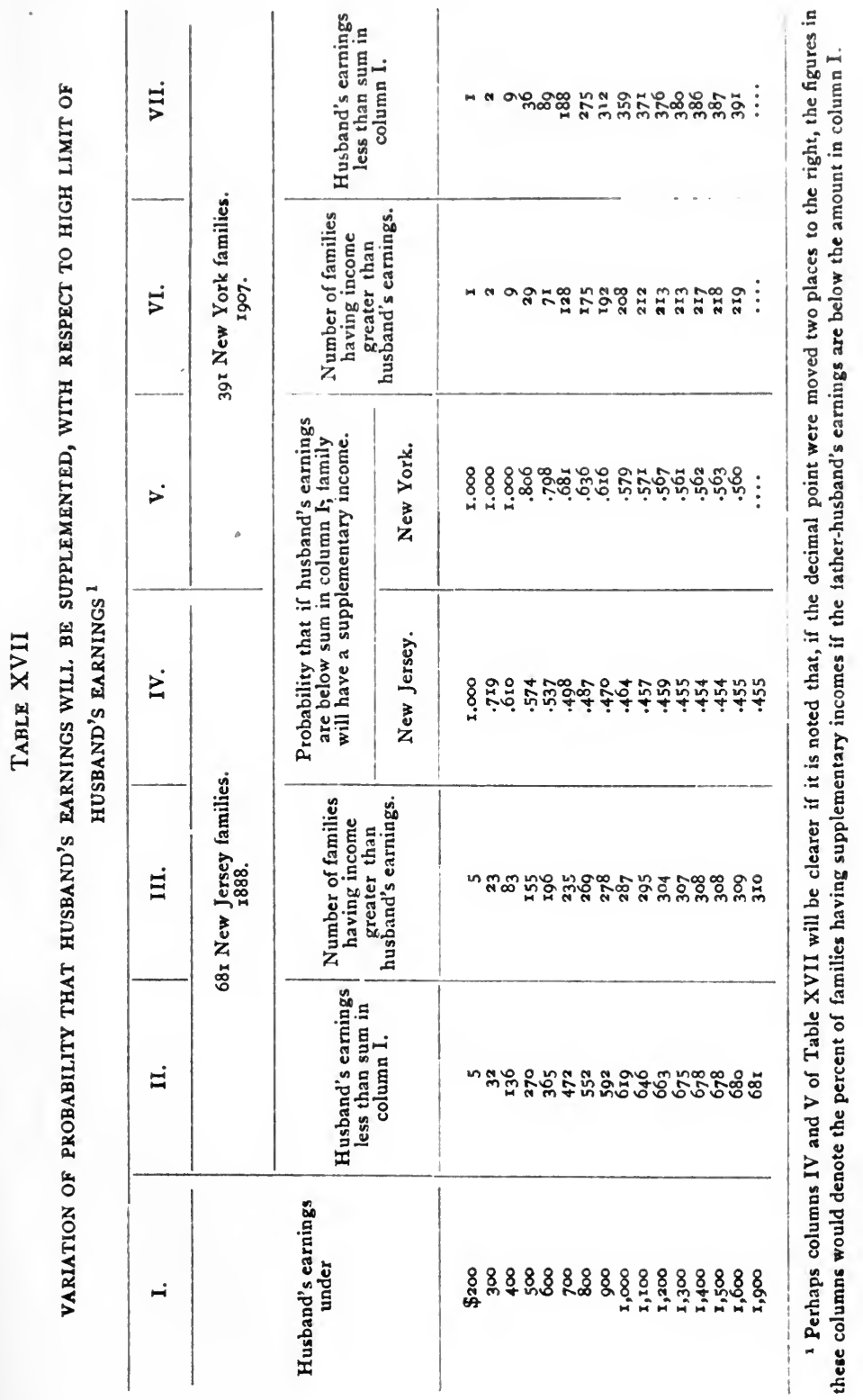


This means that, not including the agricultural population, from four to five million men have each the entire financial responsibility of a home. ${ }^{1}$

The following presentation of statistics of the distribution of incomes cannot make practical recognition of these facts, because most of the published data fail to separate married from unmarried men, and, in addition, even did the distinction exist, these conclusions are too indefinite to permit of mathematical application. The discussion will, moreover, be confined mainly to the earnings of men. This is done for two reasons: first, if an attempt were made to cover the entire field of wage statistics, the essay would be unprofitably prolonged, it being impossible, in the present state of information, to combine the wages of men, women, and children, and thus to develop an approximation of family earnings; second, it is assumed that, in an ideal state, every male of marriageable age would be given a LIVING WAGE, by which is meant an earned income sufficient both to maintain the physical and mental efficiency of every member of a normal family and also to provide for the common emergencies of life-accident, sickness, unemployment, and old age. The first reason needs no defense, the second, perhaps, does. To maintain that society would be better off if all women were productively employed, child rearing in the home not being considered productive labor, is certainly plausible. Doubtless, a large proportion of

1 Of 864 families having children at work in the glass industry, 314 , or 36.3 per cent, were households in which economic necessity compelled the parents to send their children to the factories. Other motives for child labor were probably just as important as the need of their earnings, particularly the desire to have boys learn a trade. Thus other elements than the ability of the father as a provider enter into the causaticn of work by other members of the family. See the Report on the Condition of Woman and Child Wage-Earners, vol. iii, pp. 586,587 . 
mothers are so unfit to train their offspring, that it might really be wise to entrust all children to the care of specialists, perhaps in the day nursery, perhaps continually. This would free the mother to aid in increasing the world's stock of good things, permit the preparation of food by expert dieticians, and give every girl and boy the advantage of the latest material appliances, prompt medical attention, and excellent discipline. The success of Sparta in wholesale public training of youth is an indisputable fact, and it is equally true that Daniel was reared, at least from the later years of childhood, as a ward of the state. Although this argument is reasonable, and in some ways attractive, it does not necessarily carry conviction. The modern tendency in caring for dependent children seems to be all the other way: the "cottage plan" has largely discredited the large asylum with one building; the "placing-out system" seems more and more to be winning its way. There appears to be scientific recognition of the need of the child for " mothering", not as a matter of sentiment, but as a requirement of its mental and moral health. Now, if the mother is to care for her young children, the father must be earning enough to support the family during a period of several years: as men are made, it would be nonsense to say that each should have accumulated enough before marriage to tide him through these years, and at any rate, he should also be saving against the sickness almost sure to come eventually, or against old age. State aid to mothers with dependent children would tend to put a premium upon improvidence, and might entail some of the evil consequences of the old English Poor Law. The policy of paying larger wages to married than to single men, while idealistic, would very probably cause employers to give the preference to bachelors, and thus indirectly encourage prostitution. On the other hand, the wholesale or public 
care of children will not, in all likelihood, be undertaken, before Socialism has made considerable progress. Thus whatever the merits of this question of child rearing, for society as at present organized, it is not an irrational ideal that every man should receive at least a LIVING WAGE. ${ }^{1}$ For these two reasons, therefore, this study is confined to the earnings of men.

Before examining the latest statistics, it may be well to note the progress that has recently been made in raising pay. Reliable wage data have not been published for many decades, but there is an extremely interesting set of figures in the volume containing the report of the New York State Census of 1865 . The number of men engaged in manufactures receiving each an amount from eight to a hundred twenty-eight dollars a month is given separately for each county and for the commonwealth. The rule for the enumerators required that, if board was given as part of the compensation, its value should be added to the money wages in computing the pay. Since there is a marked concentration upon multiples of five, and especially of ten dollars, in the following summary table, the monthly remuneration is given in five-dollar groups having multiples of five as their centers.

1 For an argument for the Living Wage, see Professor John A. Ryan's book, $A$ Living Wage. 
TABLE XVIII

MONTHLY WAGES OF MEN IN MANUFACTURES, NEW YORK STATE, $1865^{1}$

\begin{tabular}{|c|c|c|c|}
\hline 1. & II. & III. & IV. \\
\hline Monthly wages. & Number of men. & Monthly wages. & Number of men. \\
\hline $\begin{array}{l}\$ 8-\$ 12 \ldots \ldots \ldots \ldots \\
13-17 \ldots \ldots \ldots \ldots \\
18-22 \ldots \ldots \ldots \ldots \\
23-27 \ldots \ldots \ldots \ldots \\
28-32 \ldots \ldots \ldots \ldots \\
33-37 \ldots \ldots \ldots \ldots \\
38-42 \ldots \ldots \ldots \ldots \\
43-47 \ldots \ldots \ldots \ldots \\
48-52 \ldots \ldots \ldots \ldots \\
53-57 \ldots \ldots \ldots \ldots \\
58-62 \ldots \ldots \ldots \ldots \\
63-67 \ldots \ldots \ldots \ldots \\
68-72 \ldots \ldots \ldots \ldots \\
73-77 \ldots \ldots \ldots \ldots\end{array}$ & $\begin{array}{r}108 \\
255 \\
2,673 \\
3,361 \\
6,514 \\
9,437 \\
14,781 \\
8,555 \\
15,866 \\
4,944 \\
8,063 \\
4,536 \\
2,850 \\
1,427\end{array}$ & 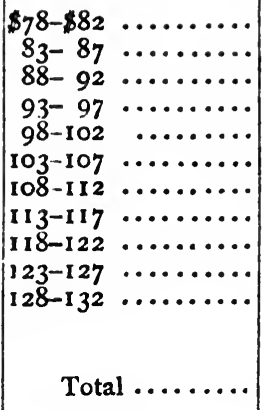 & $\begin{array}{r}2,475 \\
1,381 \\
274 \\
177 \\
767 \\
\cdots \cdots \\
273 \\
60 \\
173 \\
10 \\
2\end{array}$ \\
\hline
\end{tabular}

For the sake of comparison, the results of the federal Census of Manufactures in 1904 are presented, the returns covering 40 per cent of the wage-earners in the factories of the State in that year.

\section{TABLE XIX}

WEEKLY WAGES OF MEN IN MANUFACTURES, SIXTEEN YEARS AND OVER, NEW YORK STATE, $1904^{2}$

\begin{tabular}{|c|c|c|c|}
\hline I. & II. & III. & IV. \\
\hline Wage group. & Number of men. & Wage group. & Number of men. \\
\hline 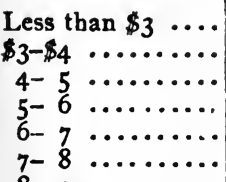 & $\begin{array}{r}5,007 \\
7,174 \\
9,742 \\
11,403 \\
15,534 \\
21,706\end{array}$ & 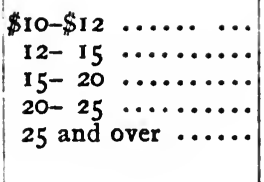 & $\begin{array}{r}49,574 \\
57,275 \\
51,666 \\
16,574 \\
9,300\end{array}$ \\
\hline $\begin{array}{l}8-9 \\
9-10\end{array} \ldots \ldots \ldots \ldots$ & $\begin{array}{l}23,450 \\
39,985\end{array}$ & Total ......... & 318,390 \\
\hline
\end{tabular}

${ }^{1}$ New York'State Census, 1865, pp. 512 et seq., compiled.

'Census of Manufactures, 1905, pt. iv, p. 743. 
From the earlier figures, it appears that the mean wage in New York in 1865 for the men engaged in manufactures was $\$ 48.19$ per month, or $\$ 11.09$ per week. In 1904, the average weekly pay for males, sixteen years of age and over, was \$Ir.79. ${ }^{1}$ These averages, however, cannot be accepted without qualification. In 1865 , the men were probably paid in greenbacks which were worth, in gold, about 0.636 of their face value. At that rate $\$ 11.09$ in greenbacks would buy as much as $\$ 7.05$ in gold, but, since Falkner's index number of prices was 100.3 for 1865 , and 93.3 for 1904, the \$11.09 earned weekly by the operative in 1865 had a purchasing power equal to only $\$ 6.57$ in 1904. ${ }^{2}$ If Falkner's index number of greenback prices be used, the value of the weekly wage of 1865 is reduced still further to $\$ 4 \cdot 77,{ }^{3}$ in purchasing power in 1904. This much, at least, is certain - in forty years, the average real wages of male factory operatives in New York State increased over eighty per cent. ${ }^{4}$

Has this improvement in remuneration been continuous up to the present time, or has it ceased during the last two decades? The Bureau of Labor index number of wages (full-time weekly earnings per employee) was ror.o for I890, 104.I for 1900, and II 2.2 for 1904, rising to I22.4 in 1907, the last year for which it was made public. ${ }^{5}$ The purchasing power of full-time weekly earnings, measured by retail prices of food was 98.6 in $1890,103.0$ in 1900 ,

${ }^{1}$ Census of Manufactures, 1905, pt. iv, p. 670.

'Johnson, Money and Currency, pp. II2, 279.

$$
{ }^{8} 11.09 \times \frac{93.3}{216.8}=4.77
$$

4 It is possible that some allowance should be made for boys under sixteen included in the 1865 figures. The caption, however, reads "Men," and nothing is said of "Children" in those pages of the New York report.

${ }^{5}$ Statistical Abstract of the United States, 1908, p. 233. 
100.4 in 1904, and 101.5 in 1907. These figures would seem to indicate that, although the general tendency of money wages to increase has not been seriously checked, there was no great gain in purchasing power. This index number, however, was not constructed in the most desirable manner, the system of weighting being open to criticism. It would, therefore, be well to seek other evidence. In 1907, Professor Henry L. Moore made a summary of the wage statistics of thirty of the industries treated in the Dewey Report. The following table presents a condensation of his results compared with those of the 1905 Census of Manufactures.

TABLE XX

WAGES IN MANUFACTURES IN THE UNITED STATES, CLASSIFIED WEEKLY EARNINGS OF MALES SIXTEEN YEARS AND OVER ${ }^{1}$

\begin{tabular}{|c|c|c|c|c|c|c|}
\hline I. & II. & III. & IV. & V. & VI. & VII. \\
\hline \multirow{2}{*}{ Wage group. } & \multicolumn{3}{|c|}{ Numbers } & \multicolumn{3}{|c|}{ Per cents. } \\
\hline & 1890. & I 900. & I904. & 1890. & I 900. & I904. \\
\hline 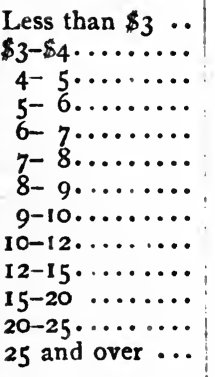 & $\begin{array}{r}444 \\
2,329 \\
3,723 \\
2,735 \\
6,435 \\
9,529 \\
8,184 \\
12,372 \\
18,750 \\
18,234 \\
15,422 \\
3,913 \\
2,853\end{array}$ & $\begin{array}{r}591 \\
2,646 \\
4,331 \\
3,880 \\
7,926 \\
15,727 \\
1,2,2: 3 \\
23,686 \\
25,375 \\
31,403 \\
23,384 \\
4,427 \\
3,446\end{array}$ & $\begin{array}{r}56,346 \\
57,597 \\
87,739 \\
103,429 \\
161,940 \\
196,981 \\
207,954 \\
343,812 \\
409,483 \\
450,568 \\
385,647 \\
106,046 \\
51,511\end{array}$ & \begin{tabular}{r|}
.42 \\
2.22 \\
3.55 \\
2.61 \\
6.13 \\
9.10 \\
7.80 \\
11.79 \\
17.87 \\
17.38 \\
14.70 \\
3.73 \\
2.70
\end{tabular} & $\begin{array}{r}.37 \\
1.66 \\
2.71 \\
2.43 \\
4.95 \\
9.83 \\
8.27 \\
14.80 \\
15.83 \\
19.62 \\
14.61 \\
2.78 \\
2.14\end{array}$ & $\begin{array}{r}2.2 \\
2.2 \\
3.4 \\
4.0 \\
6.2 \\
7.5 \\
7.9 \\
13.1 \\
15.6 \\
17.2 \\
14.7 \\
4.0 \\
2.0\end{array}$ \\
\hline $\begin{array}{l}\text { Totals } . . . \cdots \\
\text { Averages } . . .\end{array}$ & $\begin{array}{r}104,923 \\
\$ 11.57\end{array}$ & $\begin{array}{l}160,055 \\
\$ 11.5^{2}\end{array}$ & $\begin{array}{r}2,619,053 \\
\$ 11.16\end{array}$ & & 100.00 & 100.0 \\
\hline
\end{tabular}

${ }^{1}$ I 890 and 1900 figures give wage rates, as compiled by H. L. Moore from the Dewey Report, Political Science Quarterly, vol. xxii, pp. 66, 67; 1904 figures from Census of Manufactures, 1905, pt. iv, p. 645show earnings, not rates. 
Professor Moore's work revealed the startling truth that between I 890 and 1900 the average rate of pay, in the identical establishments which furnished the data for the Dewey Report, actually decreased from $\$$ I I.57 to $\$ I$ I.52. He further showed that the standard deviation had decreased from 5.309 to 5.017 , and the coefficient of variation from 45.9 to $43.5{ }^{1}$ That the mean of 1904 should be less than that of 1900 is not surprising, because the Dewey Report presented rates of wages, the later Census, actual earnings. Nevertheless, in the face of these facts, it would be absurd to hold that there has been any marked increase in the money wages of males employed in manufacturing between I890 and I904, the most recent year for which general statistics are available. Using the data in Column IV of Table XIX, a rough average of $\$ I I .46$ is obtained, a standard deviation of 5.12 and a coefficient of variation of 44.7 . This approximate coefficient of variation would seem to indicate a lessened tendency to concentrate about the mean. Although these constants for the latest year are not precisely determined, they are not far wrong, for the same tendency can be observed in the distribution as shown in the table: for instance, in I890, 2.64 per cent; in 1900, 2.03, and in 1904, 4.4 were earning less than $\$ 4$ per week. The corresponding percents for those receiving less than \$Io per week were $43.62,45.02$, and 46.5 ; for those paid less than $\$ 12$ per week they were 6I.49,60.85, and 62. I; and for those receiving $\$ 20$ or more, the percents were 6.43 in I890, 4.92 in I900, and 6.0 in I904. The conclusion, then, seems warranted that between 1890 and I904 there was no perceptible increase of the average money wages of male factory operatives, and that for the first decade of the

${ }^{1}$ The standard deviation and the coefficient of variation are measures of distribution about the mean. The smaller these are, the more are the earnings concentrated about some point. 
period there was a tendency for wage rates to concentrate about the mean, a trend which, in the next five years, was probably reversed. ${ }^{1}$

In contrast to these figures for the nation as a whole, the proportion of men in factories earning less than $\$ 8$ per week, fell between 1897 and I908 from 36.0 to 17.4 per cent in New Jersey, and from 32.2 to I3.5 in Massachusetts; likewise, the percent of those receiving less than \$I2 per week decreased from 68. I to 56.7 in the former and from 67.7 to $5 \mathrm{I} .7$ in the latter commonwealth. ${ }^{2}$ Thus, the decline being almost regular, it would appear that in these two important industrial states there has been an actual improvement in the distribution of money wages of the men engaged in manufacture. It is impossible to determine the change in average weekly pay in these two states, but it is certain that the average annual earnings of all employees in the factories of Massachusetts have been considerably augmented. ${ }^{3}$ In New York, the index number for per diem compensation of all organized working men increased from 96 in 1897 to 199 in I908, and for halfyear's earnings, from 93 to III. Although these averages are unweighted, they cannot misrepresent the general tendency, for only four trades, cloth hat and cap makers, cloak makers, longshoremen, and machine wood-workers, suffered a decrease in the average daily wage during this

${ }^{1}$ It must not be forgotten that these conclusions deal with money rates and earnings only. The purchasing power of money fell in this period. On the other hand, no figures have been given for the age composition of the operating forces of the establishments considered at these different periods. A change in this, or in the ratio of skilled to unskilled laborers might materially affect the average wage rates without changing the pay for a given kind of work.

Streightoff, Standard of Living, Appendix A and B; also chart, p. 53 .

Ibid., p. 47. 
period. In nearly every occupation both the average daily and the average half-yearly earnings were higher in 1904 than in 1897 or in $1900 .{ }^{1}$ During 1907 , half-yearly earnings were at a maximum, I22, daily wages being II8. Between 1897 and 1907, the Bureau of Labor index of retail prices of food rose from 96.3 to I20.6. Thus, in these ten years, daily money wages increased an average of 23 per cent, retail food prices 25 per cent, and half-yearly money earnings $3 \mathrm{I}$ per cent. A computation combining these percents would be inexact because the index number of New York wages is not a weighted average, and because the relative prices of food represent the country as a whole; food prices for the North Atlantic States increased 23 per cent. ${ }^{2}$

1 New York, Annual Report of the Bureau of Labor Statistics, Igo8, pt. ii, pp. xxiii, xxviii et seq.

2 Statistical Abstract of the United States, I908, p. 558. The Bureau of Labor index of retail food prices was discontinued after 1907. As to wholesale prices, not a completely reliable guide to retail prices, the general index rose from 1897 to I9I0, from 89.7 to 131.6 , or 46.7 per cent. In the same period wholesale prices of food rose from 87.7 to 128.7, or 46.8 per cent. (Bulletin of the Bureau of Labor, no. 93, pp. 318, 321.)

In this period the index of daily wages in New York rose from 96 to 124 , or about 29 per cent, and the index of quarterly earnings from 94 to 124 , or about 32 per cent. (See Table XXIX in this essay.)

The following table shows the latest wage data published by the Interstate Commerce Commission. Column V shows the increase in the average wages for each occupation, and column VI reduces this increase to per cents. From I900 to I9I0 wholesale prices for all commodities in the United States rose from II0.5 to I3I.6, or I9.I per cent; wholesale food prices rose from 104.2 to 128.7 , or 23.5 per cent. The average wages in seven branches of railway service, now embracing 601,000 men, rose less than I9.I per cent. In each of thirteen occupations, embracing $1,208,000$ employees (in I910) it rose less than 23.5 per cent. These figures tempt rash interpretations, but it is at least safe to say that the daily wages of railway employees have not increased much faster than the cost of living; perhaps they have fallen off a little in purchasing power. It is interesting to note that, except for the "switchtenders, crossing-tenders and watchmen;" the least increase was that in 
To sum up, then, the Bureau of Labor index number shows a rise of three per cent in average full-time weekly money wages from 1890 to 1900 , of eleven per cent from 1890 to 1904, and of twenty-one per cent from 1890 to 1907, while the purchasing power of these wages rose four

the pay of "general office clerks." There may be a tendency to employ women in this work.

COMPENSATION OF EMPLOYEES OF THE RAILWAYS OF THE UNITED STATES, SHOWING INCREASE OF DAILY WAGES, 1900 TO $19 \mathrm{IO}^{1}$

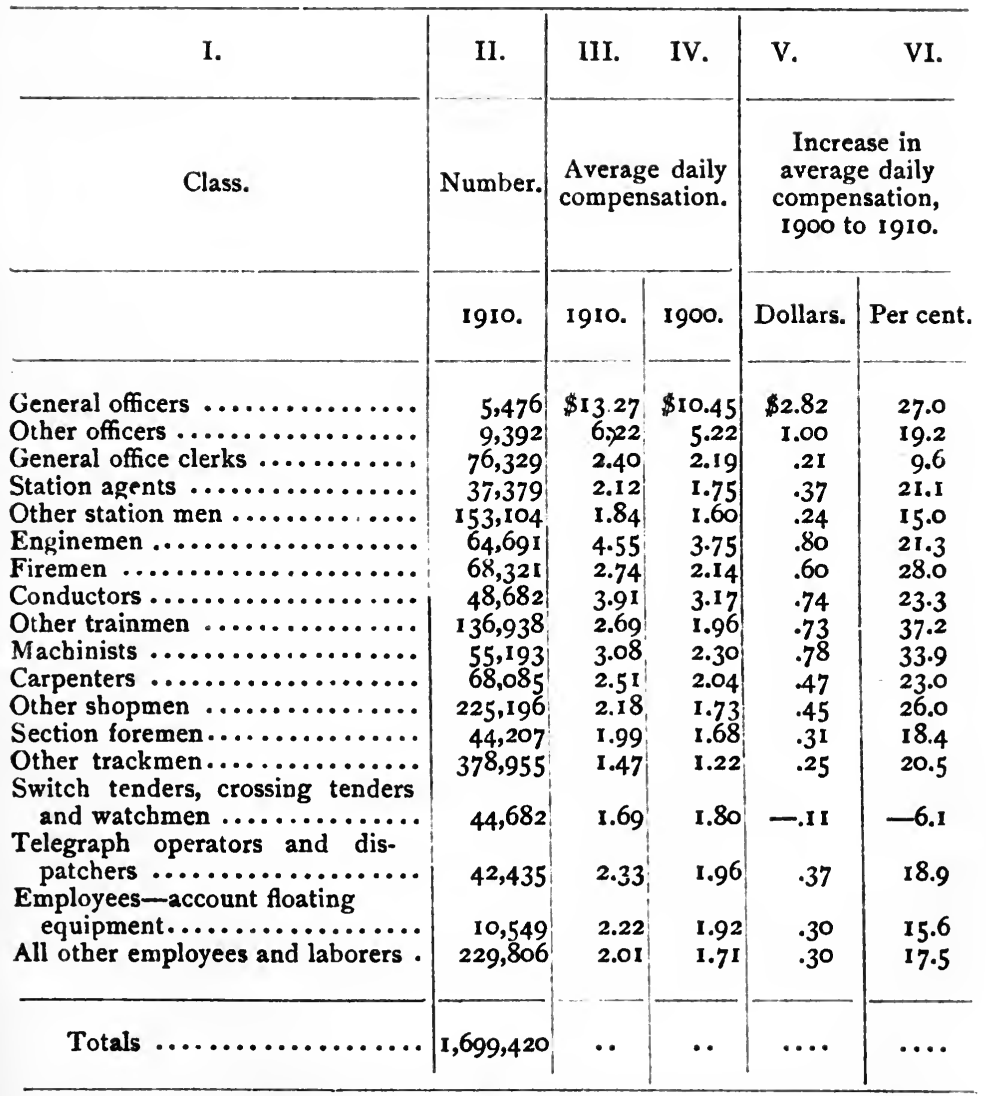

${ }^{1}$ Statistics of the Railways for year ending June 30, 1910, pp. 33, 38. 
and a half, two, and three per cent respectively for these intervals. On the other hand, the Dewey Report and the Census of Manufactures of 1905 indicate an actual decrease of the average money compensation of factory workmen, and, because more concentrated about the mean, a somewhat less favorable distribution of earnings. The statistics of Massachusetts and of New Jersey make it evident that in these two states, each year a smaller proportion of men are in the low-wage groups. There was a considerable rise, in the decade ending I907, of the average daily and half-yearly earnings of the organized workmen of New York; yet in purchasing power of food, it is doubtful if these daily wages have increased at all; in value, the halfyearly labor incomes may have gained five per cent, but from I 897 to I9 Io they probably decreased. The evidence is, therefore, conflicting ; ${ }^{1}$ but it points surely to the conclusion that there was no great improvement in the money compensation of factory operatives between I890 and I904, and that if there has been an increase of the pay of workmen in late years, it has been largely, if not entirely, offset by rapidly rising prices.

The reason for this searching inquiry into the truth of the prevalent belief that there was a large increase in wages during the last two decades, is to show clearly that, in so far as labor earnings are an index, there is no ground for believing that these years witnessed any startling change in the distribution of incomes. From the fact, then, that certain statistics were compiled in I900, or in 1904, it does not inevitably follow that they grossly misrepresent the state of affairs in I9I2. On the other hand,

1 The factor of unemployment has not been considered. Unemployment seems to be periodic: it varies widely from year to year, but it would be difficult to show that it has been growing any less burdensome of late. See reports of the New York Bureau of Labor Statistics, especially Bulletin, Department of Labor, no. 48, Sept. IgI I, p. 344. 
it cannot be maintained that the figures of the Twelfth Census are truly typical of the present. The only excuse for presenting data now over ten years old, is that nothing more recent is available, and that, as long as its true character is recognized, approximate knowledge is better than absolute ignorance.

In the field of manufactures, the Census of 1905 furnishes the most recent data of general scope. Table XXI exhibits the distribution of weekly earnings among males, aged sixteen years or over, engaged in this branch of industry in the United States in 1904:

TABLE XXI'

CLASSIFIED WEEKLY EARNINGS OF MALES, SIXTEEN YEARS AND OVER, ENGAGED IN MANUFACTURE IN THE UNITED STATES IN 1904

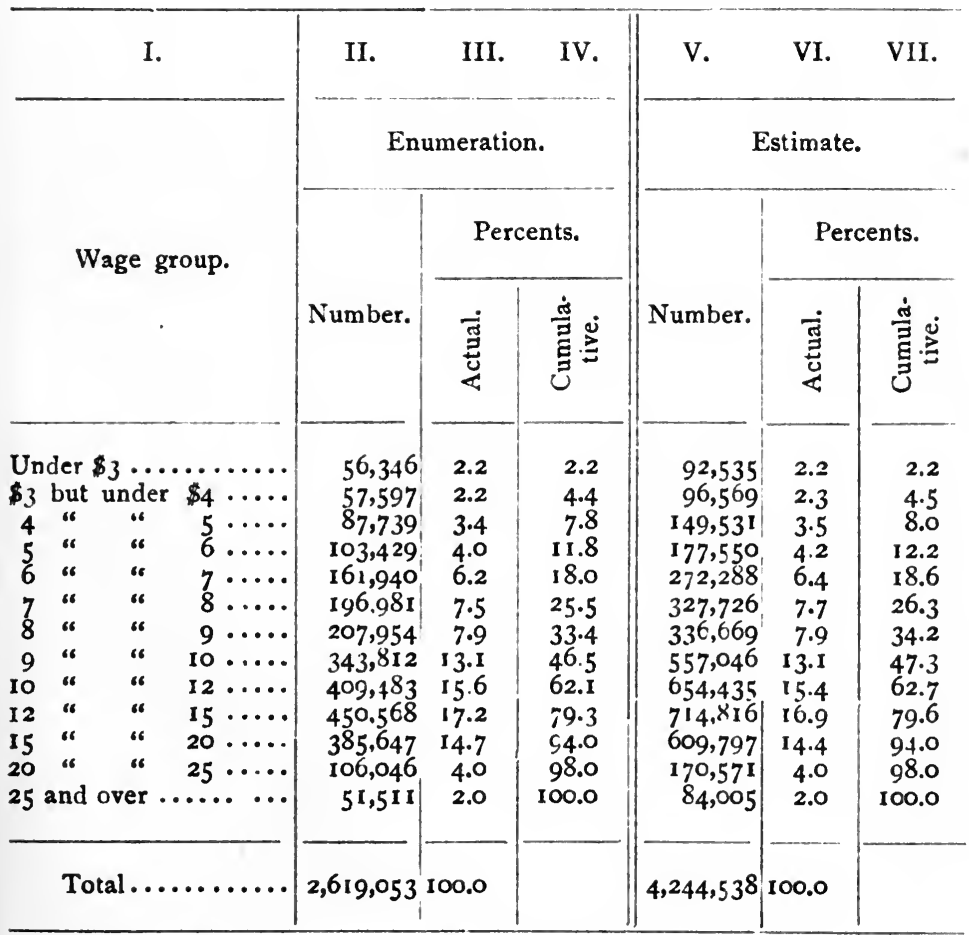

${ }^{1}$ Census of Manufactures, 1905, pt. iv, pp. 645, 647. 
If the estimate is more exactly representative of the conditions in the United States as a whole, than is the enumeration, the differences are trifling. These figures show that over forty-six per cent of the men employed in factories were actually earning less than $\$ 10$ per week, or $\$ 522$ per annum; more than sixty per cent received less than $\$ \mathrm{I} 2$ weekly or $\$ 626$ in the year; on the other hand, some six per cent were so fortunate as to enjoy a weekly compensation of at least $\$ 20$, or, for the twelve months, full-time earnings of $\$ \mathrm{I}, 043$. Of these four million two hundred thousand men, in other words, in excess of two million six hundred thousand were laboring for compensation at a rate which in the year would have netted them under $\$ 626$, and less than two hundred and sixty thousand would have received more than $\$ \mathrm{I}, 043$ if they had earned in every week as much as in the one represented in the Census returns. Two comments may be made on the interpretation of this statement: first, since the "busy week", the week when the greatest number were employed in each establishment, was chosen for the enumeration, the count may have included an unusually large proportion of extra hands; these " extras" may have been mainly non-skilled workers, and, therefore, low paid; second, the remuneration of these "men" is not typical of the recompense of fathers of families. The first observation is merely a surmise, the second expresses known facts. The average wages of women in factories, mills, and stores reaches a maximum after sixteen years of service. ${ }^{1}$, Again, the compensation of males in the Massachusetts cotton factories attains a maximum at the age period forty-five to forty-nine, in North Carolina exactly twenty years earlier, but, in the southern state, the

1 Report on Condition of Women and Child Wage-Earners in the United States, vol. v, pp. 42, 47 ; also vol. i, p. 314. 
high rate continues over a decade. The average male factory operative does not begin to approach his full earning power until he passes his twentieth birthday. Doubtless a considerable number of these four million, two hundred thousand men were below the age of twenty, but since it is improbable that many of the youths had their own families, it is a safe inference that by the time a man is ready to marry, he should normally have passed beyond the lowest earnings groups. The truth of the statement seems to be in a measure confirmed by Table XXII. This table was

\section{TABLE XXII}

COMPARISON OF THE CLASSIFIED RARNINGS OF HEADS OF FAMILIES WITH CLASSIFIED WAGE RATES OF MALES SIXTEEN YEARS AND OVER, ALL FACTORY EMPLOYEES

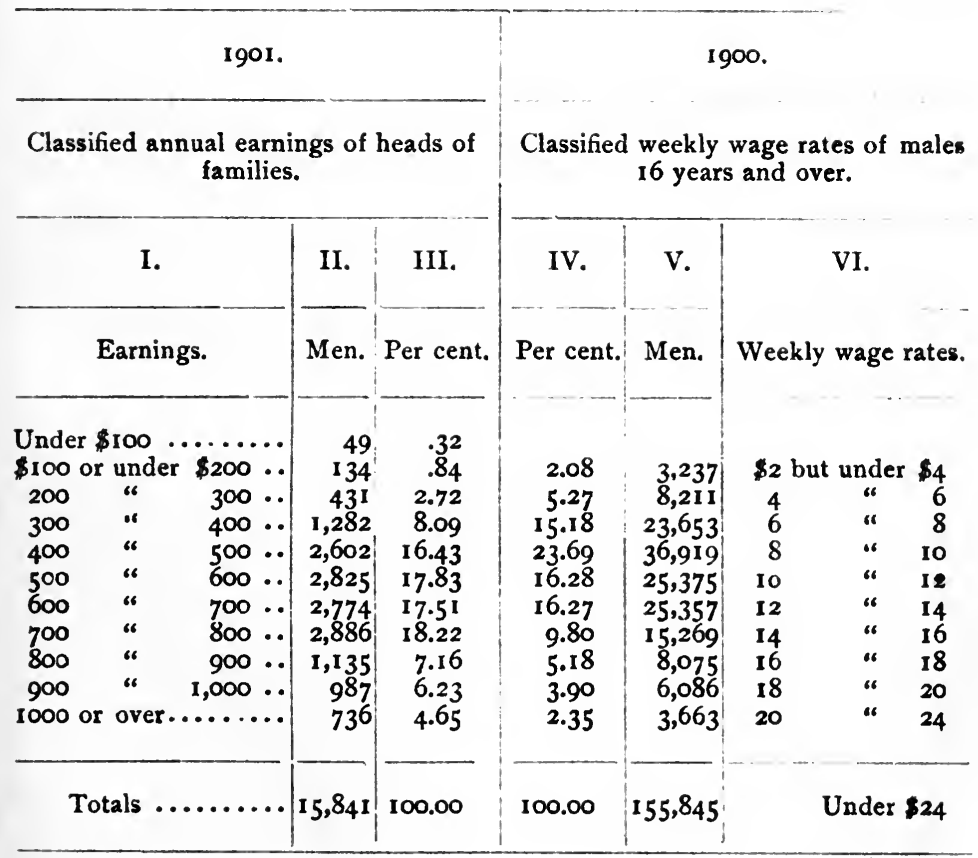


constructed as follows: from the data in the Eighteenth Annual Report of the Commissioner of Labor, were selected those dealing with the distribution of annual earnings among the heads of households who were engaged in various branches of manufacture. ${ }^{1}$ Thus, columns II and III were obtained. Since that study was confined to families having incomes under $\$ \mathrm{I}, 200$, the number of men earning $\$ 24$ per week or over in Professor Moore's summary of the Dewey Report for I900 ${ }^{2}$ was subtracted from the total and the percents recalculated on this basis to give column IV. Columns II and IV are only roughly comparable because the wage rates are only approximately equivalent to the earnings groups; nevertheless, even without taking account of the losses caused by annual unemployment, the conclusion is inevitable that the pay of heads of families engaged in manufacture ranges higher than that of males over sixteen. The surprising fact is that the difference shown is not greater.

Probably the present trend of earnings in manufactures is best exhibited by a comparison of the most recent changes in classified wages. ${ }^{3}$

Table XXIII shows that for both Kansas and New Jersey, the two states for which the returns of the years I904 and 1909 are strictly comparable, there has been a movement from the lower to the higher wage groups, the better-

${ }^{1}$ Eighteenth Annual Report of the Commissioner of Labor, p. 284.

${ }^{2}$ See Table XX.

3 The figures for 1904 are taken from the Census of Manufactures for 1905, pt. iv, pp. 670, 746, and are all for men employed in manufactures, sixteen years or more of age. The figures for 1908 or 1909 are either taken, or calculated from data in the latest available reports of the respective state bureaus. Those for Massachusetts refer to males at least twenty-one years of age, those for New Jersey and Kansas to males at least sixteen, and those for Wisconsin to all males. 


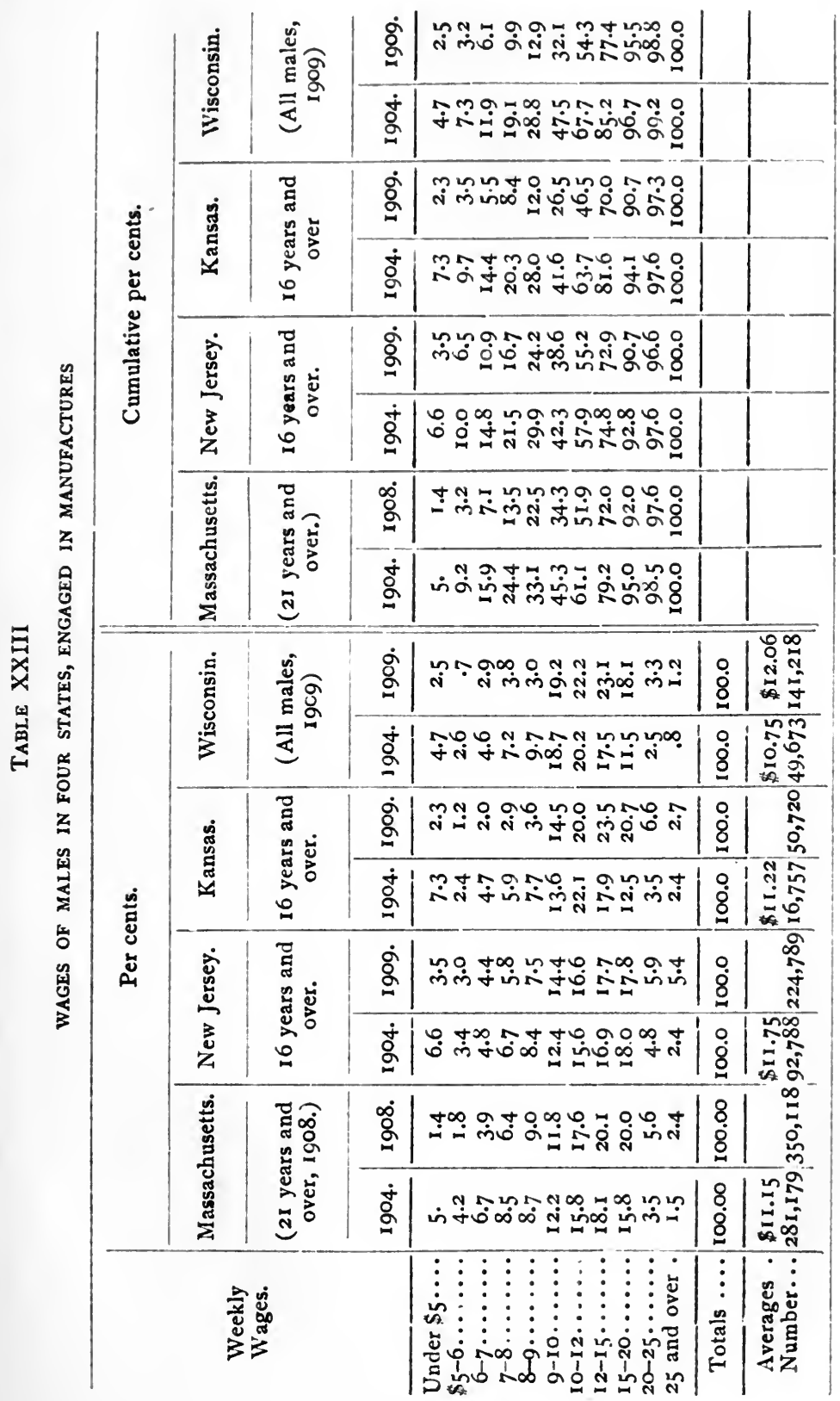


ment being especially marked in Kansas. For instance, in the younger commonwealth the proportion of men earning less than \$1 2 per week fell from 63.7 per cent to 46.5 per cent, a truly remarkable change. In New Jersey the decrease of this proportion was from 57.9 to 55.2 per cent; the greatest improvement in this state was the contraction of the very lowest wage group. In view of the fact that children under sixteen were included in the later Wisconsin enumeration, her progress was particularly great; the figures for Massachusetts are incomparable, but it has already been noted that earnings steadily increased in this commonwealth during the decade 1897 to 1907 , and the 1908 figures show no retrogression. It is, then, safe to believe that, had a general Census of Wages paid in Manufactures been taken in I9IO, it would have shown a considerable reduction in the proportion of males earning less than $\$ \mathrm{I} 2$ weekly; the percent receiving more than $\$ 20$ would have slightly increased; the principal change seems to have been in the direction of greater concentration of wages between $\$ 9$ and $\$ 20$.

The statistics of wages of factory operatives clearly indicate, therefore, that in 1904 the maximum earning power of sixty-two per cent of the adult males employed was $\$ 626$ per year, while, if they worked full time, six per cent may have received upward of $\$ \mathrm{I}, 043$. Moreover, the labor incomes of heads of families engaged in this branch of industry would range a little higher than those of adult males. Finally, the last five years for which some state figures are available, the period from 1904 to 1909 witnessed a general increase of earnings, so that at the latter date the pay of probably less than sixty per cent of the men was below $\$ 12$ per week.

Annual earnings in manufacturing seem to be slightly higher than those in other industrial pursuits. Evidence 
for this exists in the Eighteenth Annual Report of the Commissioner of Labor.

\section{TABLE XXIV'}

CLASSIFIED ANNUAI, EARNINGS OF HEADS OF FAMIIIES, I9OI

\begin{tabular}{|c|c|c|c|c|c|c|c|}
\hline I. & II. & III. & IV. & V. & VI. & VII. & VIII. \\
\hline \multirow[b]{2}{*}{ Annual earnings. } & \multicolumn{7}{|c|}{ Per cent of heads of families in } \\
\hline & $\equiv$ & 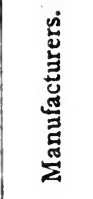 & 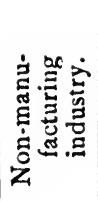 & 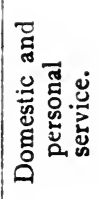 & $\stackrel{\infty}{.0}$ & 总 & 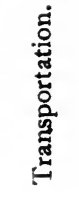 \\
\hline Under $\$ 100 \ldots . . . .$. & $\cdot 37$ & .32 & .48 & 1.34 & $\cdots$ & .18 & .22 \\
\hline$\$ 100-\$ 200 \ldots \ldots \ldots$ & I.I I & .84 & 1.59 & 2.04 & 1.98 & $.5^{8}$ & .77 \\
\hline $200-300 \ldots \ldots \ldots$ & 3.02 & 2.72 & 3.56 & $5 \cdot 57$ & 6.73 & 2.53 & 2.02 \\
\hline $300-400 \ldots \ldots \ldots$ & 8.37 & 8.09 & 8.90 & 9.40 & 19.92 & $7 \cdot 36$ & 6.92 \\
\hline $400-500 \ldots \ldots \ldots$ & I 6.79 & I6.43 & 17.45 & I 5.97 & $26.5^{2}$ & $17 \cdot 79$ & 16.73 \\
\hline $500-600 \ldots \ldots \ldots$ & 17.90 & 17.83 & 18.02 & 14.48 & 16.89 & 21.21 & $19.5^{2}$ \\
\hline $600-700 \ldots \ldots \ldots$ & 17.86 & 17.51 & I 8.50 & $17 \cdot 32$ & 10.95 & 20.98 & 20.17 \\
\hline $700-800 \ldots \ldots \ldots$ & 16.85 & 18.22 & $14 \cdot 32$ & I $3 \cdot 38$ & 7.25 & 15.17 & 16.08 \\
\hline $800-900 . . . \ldots \ldots$ & 6.17 & 7.16 & $4 \cdot 34$ & 5.08 & 3.16 & 3.73 & 4.41 \\
\hline $900-1000 . \ldots \ldots \ldots$ & 6.16 & 6.23 & 6.04 & 7.86 & 4.09 & 4.84 & 5.62 \\
\hline 1000 or over...$\ldots \ldots$ & 5.40 & 4.65 & 6.80 & $7 \cdot 56$ & $2.5^{\mathrm{I}}$ & 5.63 & $7 \cdot 54$ \\
\hline Men engaged ........ & 24,402 & $15,84 I$ & $8,56 r$ & 2,010 & $75^{8}$ & 2,254 & 3,222 \\
\hline
\end{tabular}

The above table indicates that the earnings of factory operatives are somewhat higher than those of men in all the other industries covered in this report. In transportation alone is there a greater percent of heads of families earning upward of $\$ 600$ per annum. However, there is no very great difference in favor of manufacturing over trade. As far as this investigation of over twenty-four

${ }^{1}$ Eighteenth Annual Report of the Commissioner of Labor, pp. 284, 285, partly compiled. 
thousand men is concerned the industrial workers seem to be about equally well off in all of these three branches of industry. However, as the canvass upon which this table is based was confined to families with annual incomes below $\$ 1,200$, no dogmatic statement can safely be made.

Nevertheless, this investigation furnishes the most important published data upon the distribution of incomes in the United States. The summary of the results, so far as they concern the annual earnings of men, presented in Table XXIV, shows that, in I901, 47.56 per cent of the heads of families having incomes under \$1,200 earned less than $\$ 600$ per annum, 34.7 I per cent received $\$ 600$ but less than $\$ 800,12.33$ per cent $\$ 800$ and under $\$ 1,000$, and 5.40 per cent $\$ 1,000$ or more. These percentages probably do not greatly misrepresent the distribution of annual earnings among mature industrial workmen, for although, as has been pointed out, the study was confined to families having incomes under $\$ 1,200$, the fact that, whereas 12.33 per cent of the fathers were earning $\$ 800$ and under $\$ 1,000$, only 5.40 per cent received $\$ 1,000$ or more, is a pretty safe indication that, in the occupations considered, the proportion of the total number of employees enjoying compensation above $\$ \mathrm{I}, 200$ was very small. There are notable exceptions to this statement as a general proposition, particularly the railway engineers and conductors, yet in nineteen of the fifty-five occupations represented by a minimum of one hundred men, not a single individual earned over $\$ \mathrm{I}, \infty 00$, and in thirty-eight, less than four per cent received more than that amount. Moreover, in no published returns of classified wages in manufactures of all those studied in the preparation of this essay, has the proportion of adult males earning over \$25 per week exceeded four per cent, and both the Dewey Report and the Wisconsin manufacturing returns show that 
over two-thirds of the men so well paid receive under $\$ 35^{1}$ Finally, although six and a half per cent of the 68I men canvassed in New Jersey in I $888^{2}$ earned between $\$ \mathrm{I}, 000$ and $\$ \mathrm{I}, 200$, the proportion receiving $\$ \mathrm{I}, 200$ or more was but 2.6 per cent, nearly three-fourths of whom were paid less than $\$ \mathrm{I}, 300$. In Dr. Chapin's study, 4.4 per cent of the men obtained for their labor from $\$ 1,000$ to $\$ 1,200$, and 3.2 per cent above that sum. It seems, therefore, reasonable to believe that Table XXV, which is a condensation of the data on earnings in this Report of the Commissioner of Labor is, except for certain occupations, fairly representative of the distribution of annual labor incomes among the heads of industrial families in the United States in rgor.

For some of the occupations represented in Table XXV, and for a few others the individual returns of annual earnings of working men in Kansas and Iowa as summarized in Tables XXVI and XXVII, offer later data. Table XXVI shows that, with the possible exception of eighteen individuals, who did not report on this subject, the 1,574 persons who filled out the Kansas questionnaires were members of labor unions. This would lead to the expectation that the wages would be higher than those compiled in the federal report, and such is the case. Moreover, the returns for the series of years show a tendency in almost all of the occupations, both in Iowa and in Kansas, for compensation to rise. The summary Table XXVIII may be said roughly to represent the approximate distribution of incomes and earnings among the workers in these occupations from 1903 to 1907 in Kansas, and from 1905 to 1909 in Iowa.

${ }^{1}$ Moore, "Variability of Wages," Political Science Quarterly, vol. xii, p. 67; Fourteenth Annual Report, Bureau of Labor and Industrial Statistics, Wisconsin, I909-I9Io, pt. viii, p. 8 I3.

${ }^{2}$ See Table XVII, p. 93. 


\section{TABLE XXV ${ }^{1}$}

PER CENT OF HEADS OF FAMILIES IN EACH GROUP OF CLASSIFIED EARNINGS, IN OCCUPATIONS EMBRACING IOO OR MORE PERSONS (CONDENSED)

\begin{tabular}{|c|c|c|c|c|}
\hline Occupation. & $\begin{array}{l}\text { Under } \\
\$ 600 \text {. }\end{array}$ & $\begin{array}{l}\$ 600 \\
\text { but under } \\
\$ 800 .\end{array}$ & $\begin{array}{c}\$ 800 \\
\text { but under } \\
\$ x, \infty 00 .\end{array}$ & $\begin{array}{l}\$ r, \infty 00 \\
\text { or over. }\end{array}$ \\
\hline Bakers (food, etc.) $\ldots \ldots \ldots \ldots \ldots \ldots \ldots$ & 36.54 & 57.06 & 4.48 & $\mathbf{x . 9 2}$ \\
\hline & 41.79 & 53.73 & 3.73 & .75 \\
\hline & 30.12 & 60.24 & & 1.20 \\
\hline $\begin{array}{l}\text { Blacksmiths (iron and steel) } \ldots \ldots \ldots \ldots \ldots \ldots \ldots \\
\text { Blacksmiths (vehicles) } \ldots \ldots \ldots \ldots \ldots \ldots \ldots \ldots \ldots\end{array}$ & $24 \cdot 75$ & 41.59 & $3 x .68$ & I 98 \\
\hline & 27.53 & 48.55 & 20.29 & 3.63 \\
\hline 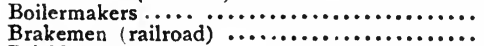 & $x 6.53$ & 4297 & $35 \cdot 54$ & 4.96 \\
\hline & 37.50 & 52.72 & $9 \cdot 78$ & $\ddot{\cdots}$ \\
\hline & 13.92 & 2782 & 46.52 & $1 x .74$ \\
\hline & 47.94 & 44.63 & 4.13 & $3 \cdot 30$ \\
\hline & 39.00 & $4 x .00$ & 17.00 & 3.00 \\
\hline $\begin{array}{l}\text { Carpenters (hand trades) } \ldots \ldots \ldots \ldots \ldots \ldots \ldots \ldots \\
\text { Carpenters (vehicles) } \ldots \ldots \ldots \ldots \ldots \ldots \ldots \ldots \ldots\end{array}$ & 40.46 & 45.84 & $x x_{0} .78$ & $x .92$ \\
\hline & $\begin{array}{l}45.05 \\
48.11\end{array}$ & $\begin{array}{l}45.95 \\
39.46\end{array}$ & $\begin{array}{r}8.10 \\
10.27\end{array}$ & $\begin{array}{r}.90 \\
2,16\end{array}$ \\
\hline 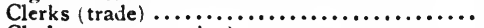 & 2607 & 42.55 & 20.21 & $x 1.17$ \\
\hline Clerks (transportation) $\ldots \ldots \ldots \ldots \ldots \ldots \ldots$ & 22.45 & $455^{8}$ & 22.45 & $9 \cdot 5^{2}$ \\
\hline Coal miners $\ldots \ldots \ldots \ldots \ldots \ldots \ldots \ldots \ldots$ & $8 r . x 8$ & $\mathbf{r 7 . 2 7}$ & $\mathbf{r . 5 5}$ & $\ldots$ \\
\hline 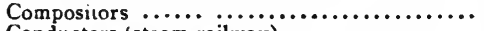 & 21.42 & $3^{8.69}$ & 25.60 & 14.29 \\
\hline Conductors (steam railway) $\quad \ldots \ldots \ldots \ldots \ldots$ & 3.23 & 1935 & 3549 & 41.93 \\
\hline Conductors istreet rallway) $\ldots \ldots \ldots \ldots \ldots \ldots$ & 28.15 & 64.82 & 7.03 & $\ldots$ \\
\hline Drivers (trade) $\ldots \ldots \ldots \ldots \ldots \ldots \ldots \ldots \ldots \ldots \ldots$ & 72.13 & 27.47 & .40 & $\cdots$ \\
\hline $\begin{array}{l}\text { Drivers (transportation) } \ldots \ldots \ldots \\
\text { Engineers (locomotive) } \ldots \ldots \ldots \ldots \ldots \ldots \ldots \ldots \ldots\end{array}$ & 63.38 & $\begin{array}{r}34.27 \\
\times 1.85\end{array}$ & $\begin{array}{r}2.35 \\
28\end{array}$ & $\ddot{\cdots}$ \\
\hline & $x .56$ & $\begin{array}{l}11.85 \\
42.73\end{array}$ & 2886 & $57 \cdot 73$ \\
\hline & 20.00 & 42.73 & 26.36 & $x 0.9 x$ \\
\hline Farm laborers $\ldots \ldots \ldots \ldots \ldots \ldots \cdots \cdots \cdots \cdots \cdots$ & 9000 & 1.00 & $\cdots$ & 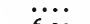 \\
\hline & $22.3^{8}$ & 58.04 & 12.59 & 6.99 \\
\hline Freight handlers $\ldots \ldots \ldots \ldots \ldots \ldots \ldots \ldots \ldots \ldots$ & 83.65 & $\mathbf{r} 6.35$ & $\cdots$ & $\cdots$ \\
\hline Hod-carriers $\ldots \ldots \ldots \ldots \ldots \ldots \ldots \ldots \ldots \ldots \ldots \ldots \ldots \ldots \ldots$ & 78.77 & $2 x .23$ & $\ddot{\cdots}$ & $\cdots$ \\
\hline Janitors $\ldots{ }^{\prime} \cdots \cdots \cdots \cdots \cdots \cdots \cdots \cdots \cdots \cdots \cdots$ & 6030 & $34 \cdot 35$ & 3.82 & $\mathrm{x} .53$ \\
\hline Laborers (domestic and personal service) ..... & 9349 & $6.5 x$ & $\cdots$ & $\cdots \cdots$ \\
\hline Laborers ifood, etc.) $\ldots \ldots \ldots \ldots \ldots \ldots \ldots \ldots$ & 93.39 & $6.6 \mathrm{r}$ & $\cdots$ & $\cdots$ \\
\hline Laborers (iron and steel) $\ldots \ldots \ldots \ldots \ldots \ldots \ldots$ & 92.30 & $7 \cdot 70^{\circ}$ & $\cdots$ & $\cdots$ \\
\hline Laborers (lumber) $\quad \ldots \ldots \ldots \ldots \ldots \ldots \ldots \ldots \ldots$ & 96.18 & 3.82 & $\cdots$ & $\cdots$ \\
\hline Laborers textiles $\ldots \ldots \ldots \ldots \ldots \ldots \ldots \ldots \ldots$ & 9933 & .67 & $\cdots$ & $\cdots$ \\
\hline Laborers (vehicles) $\ldots \ldots \ldots \ldots \ldots \ldots \ldots \ldots$ & 91.89 & 8.i 1 & $\cdots$ & $\cdots$ \\
\hline Laborers (miscellaneous manufactures). ..... & 91.03 & 8.77 & .20 & $\cdots$ \\
\hline Laborers (trade) $\ldots \ldots \ldots \ldots \ldots \ldots \ldots \ldots \ldots \ldots \ldots \ldots \ldots \ldots$ & 90.15 & 9.47 & $\cdot 38$ & $\cdots$ \\
\hline Laborers transportation ) $\ldots \ldots \ldots \ldots \ldots \ldots \ldots$ & 84.80 & $x 520$ & $\cdots$ & $\cdots$ \\
\hline Letter-carriers $\ldots \ldots \ldots \ldots \ldots \ldots \ldots \ldots \ldots \ldots \ldots \ldots \ldots \ldots \ldots$ & 6.86 & 8.82 & 49.02 & $35 \cdot 30$ \\
\hline Longshoremen...$\ldots \ldots \ldots \ldots \ldots \ldots \ldots \ldots$ & $67 \cdot 57$ & 30.40 & $x .35$ & .68 \\
\hline Machinists (iron and steel) ................ & $\pi 4.7^{2}$ & 57.67 & $24 \cdot 70$ & $2.9 x$ \\
\hline Machinists $($ vehicles $) \ldots \ldots \ldots \ldots \ldots \ldots \ldots \ldots \ldots$ & 18.83 & 52.59 & 24.03 & 4.55 \\
\hline Masons $\ldots \ldots \ldots \ldots \ldots \ldots \ldots \ldots \ldots \ldots \ldots \ldots \ldots \ldots \ldots \ldots \ldots$ & 26.19 & 40.48 & $29 \cdot 36$ & 3.97 \\
\hline Molders $\ldots \ldots \ldots \ldots \ldots \ldots \ldots \ldots \ldots \ldots \ldots \ldots \ldots \ldots$ & 18.38 & 50.22 & $27.8 \mathrm{x}$ & 3.59 \\
\hline Motormen $\ldots \ldots \ldots \ldots \ldots \ldots \ldots \ldots \ldots \ldots \ldots \ldots \ldots \ldots \ldots$ & $3^{6.15}$ & 5904 & $4.8 \mathrm{r}$ & $\cdots$ \\
\hline Painters (hand trades) $\ldots \ldots \ldots \ldots \ldots \ldots \ldots \ldots$ & $45 \cdot 35$ & $4^{1} \cdot 57$ & ro.93 & 2.15 \\
\hline 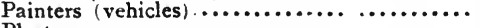 & 43.24 & 45.04 & ro.82 & .90 \\
\hline Plasterers $\quad \ldots \ldots \ldots \ldots \ldots \ldots \ldots \ldots \ldots \ldots \ldots \ldots \ldots \ldots$ & $27 \cdot 36$ & 42.45 & 22.64 & $7 \cdot 55$ \\
\hline 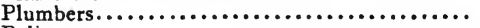 & 7.49 & 29.95 & 35.29 & 27.27 \\
\hline Policemen $\ldots \ldots \ldots \ldots \ldots \ldots \ldots \ldots \ldots \ldots \ldots$ & 5.00 & 26.66 & 45.84 & 22.50 \\
\hline Salesmen (grocery) $\ldots \ldots \ldots \ldots \ldots \ldots \ldots \ldots$ & 41.71 & $50.9^{2}$ & $4 \cdot 30$ & 3.07 \\
\hline Section hands railroad) $\ldots \ldots \ldots$ & 94.23 & $5 \cdot 77$ & & \\
\hline Stone cutters $\ldots \ldots \ldots \ldots \ldots \ldots \ldots \ldots \ldots \ldots \ldots \ldots$ & 18.92 & 33 II & 39.86 & $8.1 \mathrm{I}$ \\
\hline Switchmen (railroad) $\ldots \ldots \ldots \ldots \ldots \ldots \ldots \ldots$ & 3584 & $43 \cdot 33$ & $14 . x 6$ & 6.67 \\
\hline Tailors $\ldots \ldots \ldots \ldots \ldots \ldots \ldots \ldots \ldots \ldots \ldots \ldots \ldots \ldots \ldots$ & 5432 & 30.45 & ro. 5 & 5.08 \\
\hline Tinsmiths $\ldots \ldots \ldots \ldots \ldots \ldots \ldots \ldots \ldots \ldots \ldots \ldots \ldots \ldots \ldots$ & 36.07 & 54.09 & 8.20 & 1.64 \\
\hline All occupations (24, & $47 \cdot 56$ & $34 \cdot 7^{x}$ & 22.33 & $5 \cdot 40$ \\
\hline
\end{tabular}

${ }^{1}$ Eighteenth Annual Report of the Commissioner of Labor, pp. 283, 285 . 
TABLE XXVI

CLASSIFIED INCOMES FOR THE YEARS 1903, I904, 1906, AND 1907, FAMILY OBLIGATIONS AND ORGANIZATION MEMBERSHIP OF CERTAIN WAGEFARNERS IN KANSAS

\begin{tabular}{|c|c|c|c|c|c|c|c|c|c|c|c|}
\hline \multicolumn{2}{|c|}{ Occupation. } & $\stackrel{\text { d }}{\searrow}$ & $\begin{array}{l}\dot{8} \\
\dot{8} \\
\tilde{0} \\
\tilde{D}\end{array}$ & 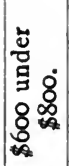 & 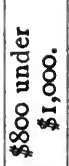 & 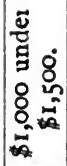 & 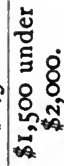 & 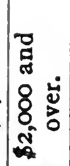 & 离 & 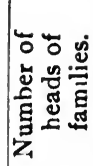 & 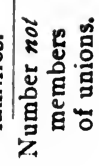 \\
\hline $\begin{array}{c}\text { Brakeman } \\
\text { "6 } \\
\text { " }\end{array}$ & $\begin{array}{l}\ldots \ldots \ldots \\
\ldots \ldots \ldots \\
\cdots \ldots \ldots\end{array}$ & $\begin{array}{l}1903 \\
1904 \\
1906 \\
1907\end{array}$ & $\begin{array}{r}2 \\
1 \\
1 \\
\cdots\end{array}$ & $\begin{array}{l}4 \\
4 \\
2 \\
1\end{array}$ & $\begin{array}{l}4 \\
1 \\
7 \\
6\end{array}$ & $\begin{array}{r}1 \\
\cdots \\
\cdots \\
1\end{array}$ & $\begin{array}{l}\cdots \\
\cdots \\
\cdots \\
\cdots\end{array}$ & $\begin{array}{l}\cdots \\
\cdots \\
\cdots \\
\cdots\end{array}$ & $\begin{array}{r}11 \\
6 \\
10 \\
8\end{array}$ & & $\begin{array}{l}1 \ldots \ldots \\
4(?) \\
9 \ldots \ldots \\
8 \ldots \ldots\end{array}$ \\
\hline Totals & & $\cdots$ & 4 & II & 18 & 2 & $\ldots$ & $\cdots$ & 35 & 32 & 2 (?) 1 \\
\hline
\end{tabular}

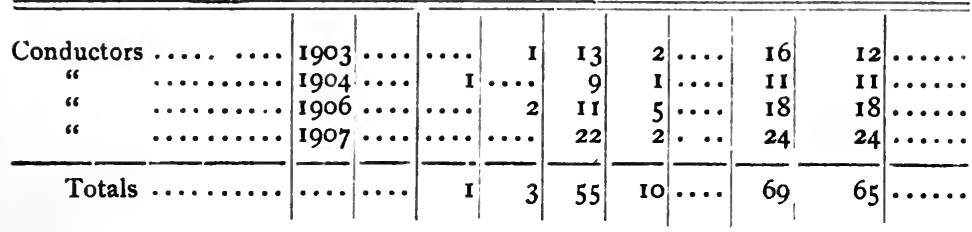

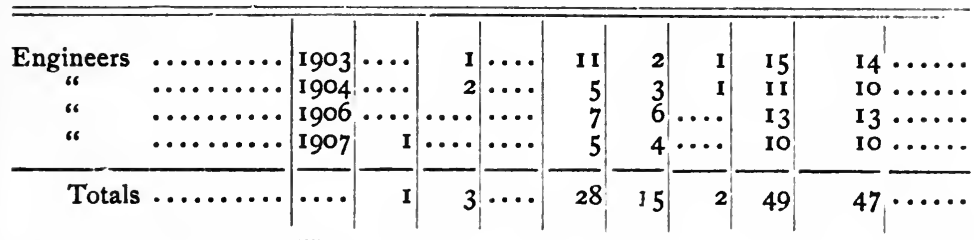

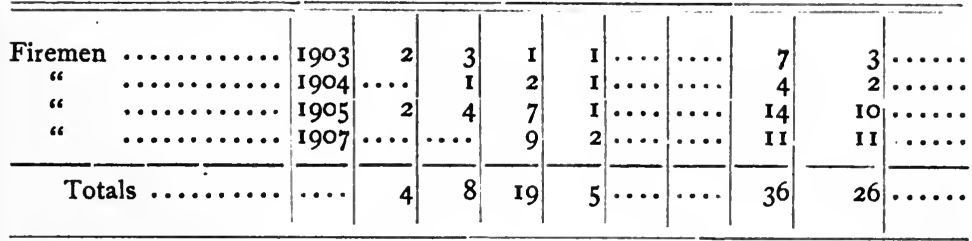

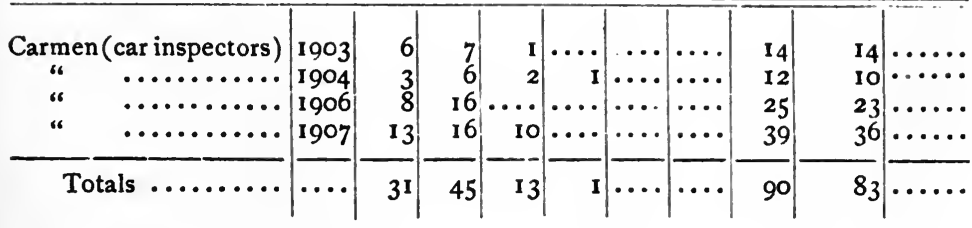


TABLE XXVI

CLASSIFED INCOMES FOR THE YEARS 1903, 1904, 1906, AND 1907, FAMILY OBLIGATIONS AND ORGANIZATION MEMBERSHIP OF CERTAIN WAGE.

EARNERS IN KANSAS-Continued

\begin{tabular}{|c|c|c|c|c|c|c|c|c|c|c|c|}
\hline \multicolumn{2}{|c|}{ Occupation. } & હ্ં & 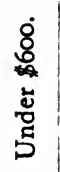 & 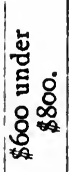 & 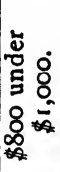 & 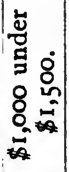 & 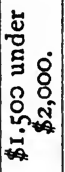 & 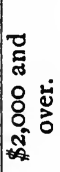 & 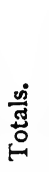 & 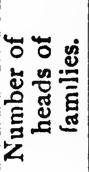 & 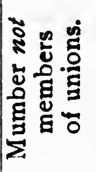 \\
\hline $\begin{array}{c}\text { Machinists } \\
\text { “6 } \\
\text { " }\end{array}$ & $\begin{array}{l}\cdots \ldots \ldots \ldots \\
\ldots \ldots \ldots \ldots \\
\ldots \ldots \ldots \ldots \\
\ldots \ldots \ldots\end{array}$ & $\begin{array}{l}1903 \\
1904 \\
1906 \\
1907\end{array}$ & $\begin{array}{r}\cdots \\
\cdots \\
\cdots \\
\cdots\end{array}$ & $\begin{array}{r}1 \\
5 \\
\cdots \\
\cdots \cdots\end{array}$ & $\begin{array}{r}8 \\
\ldots 6 \\
6\end{array}$ & $\begin{array}{r}4 \\
1 \\
10 \\
2\end{array}$ & $\begin{array}{l}\cdots \\
\cdots \\
\cdots \cdots \\
\cdots \\
\cdots\end{array}$ & $\begin{array}{l}\cdots \\
\cdots \\
\cdots \\
\cdots\end{array}$ & $\begin{array}{r}13 \\
12 \\
16 \\
6\end{array}$ & $\begin{array}{r}13 \\
11 \\
15 \\
5\end{array}$ & $\begin{array}{l}\cdots \ldots \\
\cdots \ldots \\
\cdots \cdots \\
\cdots \cdots\end{array}$ \\
\hline Total & & $\cdots \cdots$ & & & 18 & 17 & $\cdots$ & $\cdots$ & 47 & 44 & \\
\hline
\end{tabular}

\begin{tabular}{|c|c|c|c|c|c|c|c|c|c|c|}
\hline $\begin{array}{l}\text { Other railroad employ- } \\
\text { ees including black- } \\
\text { smiths, boilermakers, } \\
\text { their helpers. iron } \\
\text { molders (varying } \\
\text { numbers) ......... }\end{array}$ & $\begin{array}{l}1903 \\
1904 \\
1906 \\
1907\end{array}$ & $\begin{array}{r}8 \\
8 \\
6 \\
\ldots .\end{array}$ & $\begin{array}{r}10 \\
6 \\
6 \\
3\end{array}$ & $\begin{array}{r}12 \\
12 \\
9 \\
8\end{array}$ & $\begin{array}{r}18 \\
2 \\
1 \\
9\end{array}$ & $\begin{array}{l}\cdots \cdots \\
\cdots \cdots \\
\cdots \cdots \\
\cdots \cdots\end{array}$ & $\begin{array}{c}\cdots \cdots \\
\cdots \cdots \\
\cdots \cdots \\
\cdots\end{array}$ & $\begin{array}{l}48 \\
28 \\
22 \\
20\end{array}$ & $\begin{array}{l}41 \\
25 \\
21 \\
18\end{array}$ & \\
\hline Totals ......... & $\ldots$ & 22 & 25 & $4 \mathrm{I}$ & 30 & $\ldots$ & $\cdots$ & 118 & 105 & : \\
\hline
\end{tabular}

\begin{tabular}{|c|c|c|c|c|c|c|c|c|c|c|}
\hline $\begin{array}{c}\text { Bricklayer } \\
\text { masons } \\
\text { "؛ } \\
\text { " }\end{array}$ & $\begin{array}{c}\text { s and stone- } \\
\ldots \ldots \ldots \ldots \\
\ldots \ldots \ldots\end{array}$ & $\begin{array}{l}1903 \\
1904 \\
1906 \\
1907\end{array}$ & $\begin{array}{r}16 \\
8 \\
4 \\
3\end{array}$ & $\begin{array}{r}11 \\
9 \\
3 \\
5\end{array}$ & $\begin{array}{r}5 \\
7 \\
\cdots \\
9\end{array}$ & $\begin{array}{r}10 \\
4 \\
2 \\
1\end{array}$ & $\begin{array}{r}\mathbf{I} \\
\cdots \\
\mathbf{I} \\
\mathbf{I}\end{array}$ & $\begin{array}{l}\cdots \\
\cdots \\
\cdots \\
\cdots\end{array}$ & $\begin{array}{l}43 \\
28 \\
10 \\
19\end{array}$ & $\begin{array}{r}37 \\
23 \\
6 \\
19\end{array}$ \\
\hline Tota & ... & & 31 & 28 & 21 & 17 & 3 & & & 8 \\
\hline
\end{tabular}

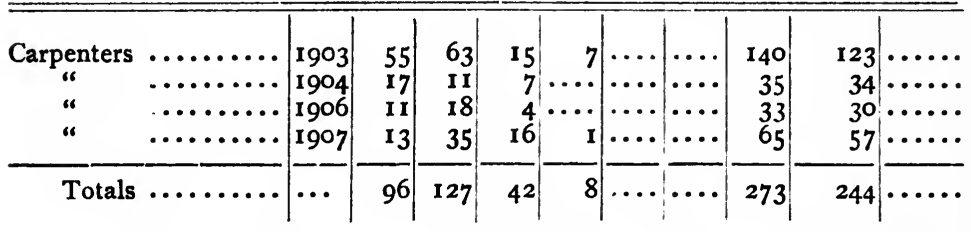

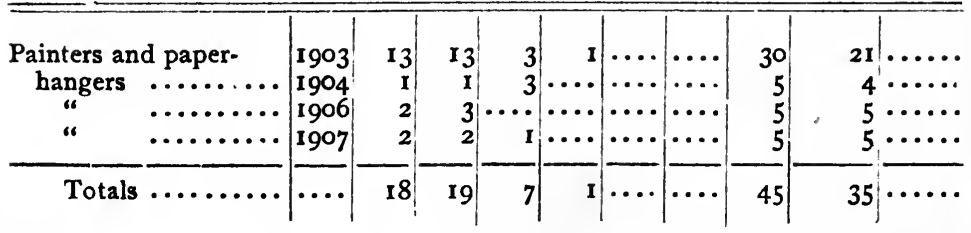


TABLE XXVI

CLASSIFIED INCOMES FOR THE YEARS 1903, 1904, 1906, AND 1907, FAMILY OBLIGATIONS AND ORGANIZATIINN MEMBERSHIP OF CERTAIN WAGE-

KARNERS IN KANSAS- Continued

\begin{tabular}{|c|c|c|c|c|c|c|c|c|c|c|c|}
\hline \multicolumn{2}{|c|}{ Occupation. } & 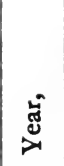 & $\begin{array}{l}8 \\
8 \\
0 \\
4 \\
0 \\
0 \\
0\end{array}$ & 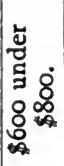 & 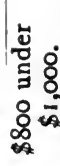 & 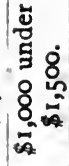 & 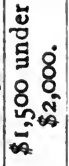 & 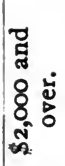 & 离 & 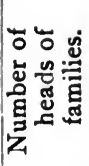 & 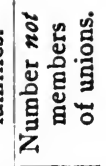 \\
\hline $\begin{array}{c}\text { Barbers } \\
\text { "6 } \\
\text { "6 }\end{array}$ & 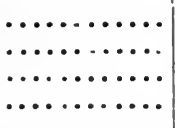 & $\begin{array}{l}1903 \\
1904 \\
1906 \\
1907\end{array}$ & $\begin{array}{r}3 \\
\text { I } \\
\text { I }\end{array}$ & $\begin{array}{r}9 \\
4 \\
25 \\
17\end{array}$ & 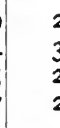 & $\begin{array}{r} \\
\ldots \\
\ldots \\
I\end{array}$ & $\left|\begin{array}{|}\cdots \cdots \\
\cdots \cdots \\
\cdots \cdots \\
\cdots \cdots\end{array}\right|$ & $\begin{array}{l}\cdots \\
\cdots \\
\cdots \\
\cdots\end{array}$ & \begin{tabular}{r|}
15 \\
7 \\
29 \\
20
\end{tabular} & $\begin{array}{r}14 \\
7 \\
20 \\
16\end{array}$ & \begin{tabular}{l|l|}
4 & $\cdots$ \\
7 & $\cdots$ \\
0 & $\cdots$ \\
6 & $\cdots$
\end{tabular} \\
\hline Tot & ls $\ldots \ldots \ldots$ & $\cdots$ & 5 & 55 & 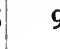 & & $\cdots$ & $\cdots$ & 71 & 57 & 7 . \\
\hline
\end{tabular}

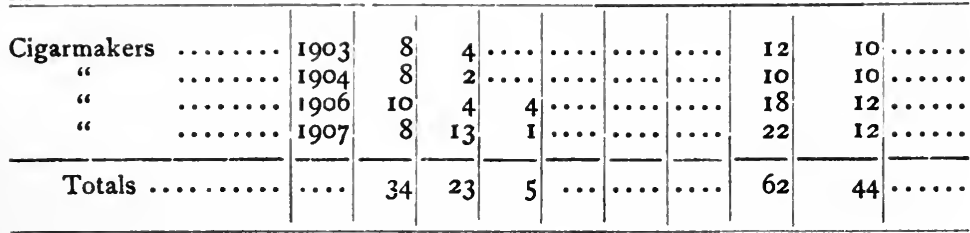

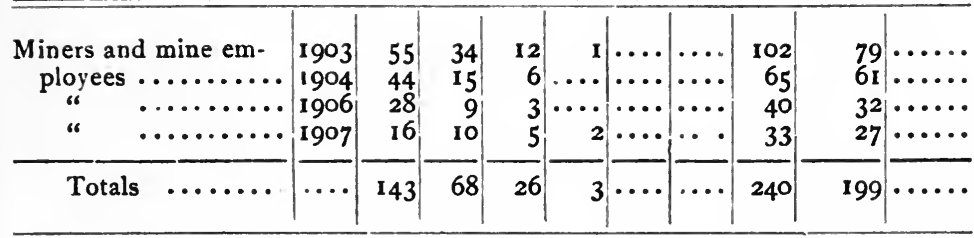

Common labnrers ( 19031903 and 1904 classed with 1904 building trades; 1907 , 1906

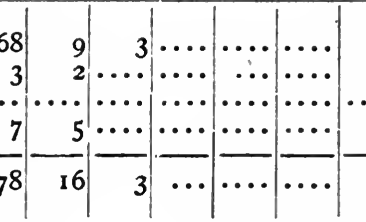
8077 with miscellaneous). 1907

Totals

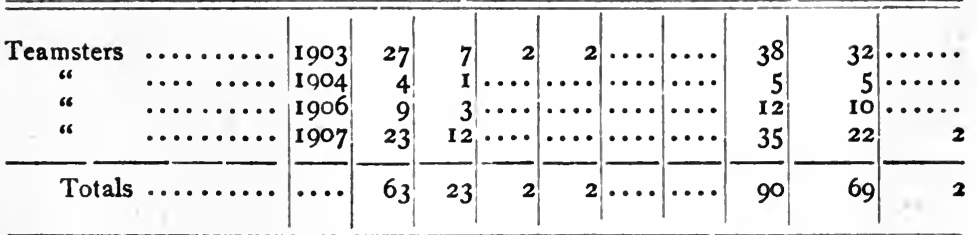


TABLE XXVI

CLASSIFIED INCOMES FOR THE YEARS 1903, 1904, 1906, AND 1907, FAMILY OBLIGATIONS AND ORGANIZATION MEMBERSHIP OF CERTAIN WAGE-

EARNERS IN KANSAS-Concluded

\begin{tabular}{|c|c|c|c|c|c|c|c|c|c|c|}
\hline Occupation. & 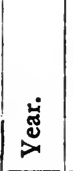 & 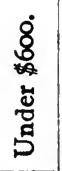 & 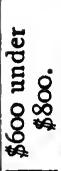 & 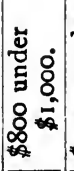 & 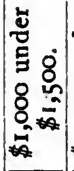 & 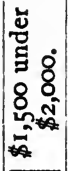 & 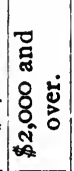 & 苂 & 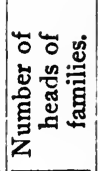 & 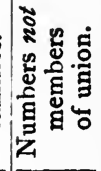 \\
\hline 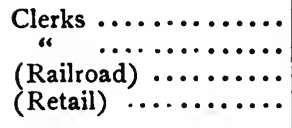 & \begin{tabular}{|l|}
1903 \\
1904 \\
1906 \\
1907
\end{tabular} & $\begin{array}{r}14 \\
3 \\
1 \\
\cdots\end{array}$ & $\begin{array}{l}7 \\
1 \\
5 \\
5\end{array}$ & $\begin{array}{r}2 \\
\cdots \\
\cdots \cdots \\
\cdots \cdots\end{array}$ & $\begin{array}{r}2 \\
2 \\
\cdots \cdots \\
\cdots \cdot\end{array} \mid$ & $\mid \begin{array}{c}\cdots \\
i \\
\cdots\end{array}$ & $\left|\begin{array}{l}\cdots \\
\cdots \cdots \\
\cdots \cdots \\
\cdots \cdots\end{array}\right|$ & $\begin{array}{r}25 \\
7 \\
6 \\
5\end{array}$ & $\begin{array}{r}13 \\
6 \\
6 \\
3\end{array}$ & 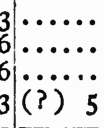 \\
\hline Totals ... & $\cdots$ & 18 & I8 & 2 & & & $\cdots$ & 43 & & 8 (?) 5 \\
\hline 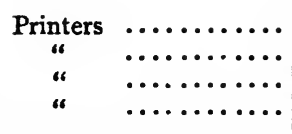 & $\begin{array}{l}1903 \\
1904 \\
1906 \\
1907\end{array}$ & $\begin{array}{l}3 \\
4 \\
2 \\
2\end{array}$ & $\begin{array}{r}7 \\
\text { II } \\
5 \\
\text { 10 }\end{array}$ & 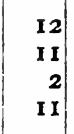 & \begin{tabular}{r|}
8 \\
12 \\
3 \\
3
\end{tabular} & $\begin{array}{r}\cdots \\
2 \\
\cdots \\
\cdots\end{array}$ & $\begin{array}{l}\cdots \\
\cdots \\
\cdots \\
\cdots\end{array}$ & $\begin{array}{l}30 \\
40 \\
13 \\
26\end{array}$ & $\begin{array}{l}24 \\
28 \\
10 \\
19\end{array}$ & \begin{tabular}{l|l}
4 & $\cdots$ \\
& $\cdots$ \\
0 & $\cdots$ \\
9 & $\cdots$
\end{tabular} \\
\hline Totals .. & $\cdots \cdot$ & II & 33 & 36 & 26 & & $\ldots$ & 109 & 81 & $\mathbf{I}$. \\
\hline
\end{tabular}

These averages are purely abstract, but, on the whole, they represent a group of incomes a little higher than at the beginning of the period, and a bit lower than at its close. Of the Kansas workmen contributing, in the four years, these I, 574 replies, nearly thirty-six per cent, were earning less than $\$ 600$ per annum, thirty-two per cent received wages amounting to $\$ 600$ but less than $\$ 800$, seventeen per cent $\$ 800$ and under $\$ 1,000$, thirteen per cent $\$ 1,000$ but less than $\$ 1,500$, and two per cent $\$ 1,500$ or more. They were mature men, members of unions. Owing largely to the preponderation of the railroad employees, but partly to the character of the returns from all the occupations, the range of earnings in Iowa is much higher. Although these figures are interesting as showing the distribution of labor incomes in these two commonwealths, for several reasons they must not be considered typical of the nation or even of these 
TABLE XXVII

CLASSIFIED EARNINGS OF CERTAIN WAGE-EARNERS IN IOWA, I905, 1907, AND I909

\begin{tabular}{|c|c|c|c|c|c|c|c|c|}
\hline Occupation. & 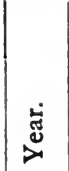 & 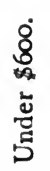 & 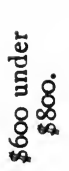 & 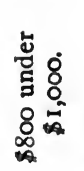 & 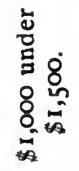 & 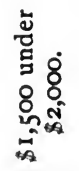 & 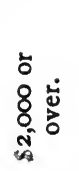 & $\stackrel{\dot{\omega}}{\tilde{\Xi}}$ \\
\hline 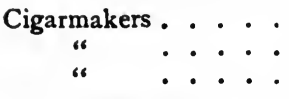 & $\begin{array}{l}1905 \\
1907 \\
1909\end{array}$ & $\begin{array}{l}5 \\
1 \\
5\end{array}$ & $\begin{array}{l}6 \\
5 \\
6\end{array}$ & $\cdot \begin{array}{l}5 \\
2\end{array}$ & $\cdot \dot{P}$ & 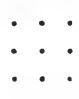 & 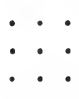 & $\begin{array}{l}\text { II } \\
\text { II } \\
14\end{array}$ \\
\hline .... & . . & I I & 17 & 7 & I & . . & . . & 36 \\
\hline
\end{tabular}

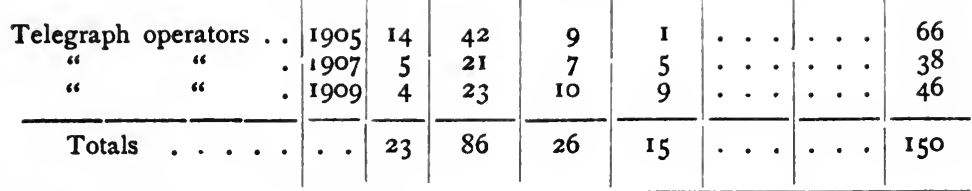

\begin{tabular}{|c|c|c|c|c|c|c|c|c|c|c|}
\hline Miners (coal) & : & $\begin{array}{l}\cdot \dot{ } \\
.\end{array}$ & $\begin{array}{l}1907 \\
1909\end{array}$ & $\begin{array}{l}12 \\
19\end{array}$ & $\begin{array}{r}4 \\
15\end{array}$ & $\begin{array}{l}3 \\
4\end{array}$ & 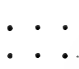 & $\begin{array}{ll}\cdot & \cdot \\
. & .\end{array}$ & $\begin{array}{l}\therefore \\
.\end{array}$ & $\begin{array}{l}19 \\
3^{8}\end{array}$ \\
\hline Totals & . & . & . & 3I & 19 & 7 & . • • & . • & • & 57 \\
\hline
\end{tabular}

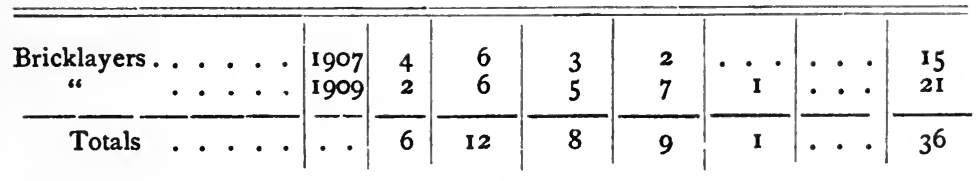

\begin{tabular}{|c|c|c|c|c|c|c|c|c|c|c|}
\hline Clerks (retail) & $\ddot{\circ}$ & $\therefore$ & $\begin{array}{l}1907 \\
1909\end{array}$ & $\begin{array}{l}5 \\
7\end{array}$ & $\begin{array}{r}10 \\
9\end{array}$ & $\begin{array}{l}1 \\
4\end{array}$ & $\cdot 5$ & $\begin{array}{l}. \\
.\end{array}$ & $\cdot \dot{I}$ & $\begin{array}{l}16 \\
26\end{array}$ \\
\hline Totals . & $\cdot \cdot$ & - • & . . & 12 & 19 & 5 & 5 & . . & I & 42 \\
\hline
\end{tabular}

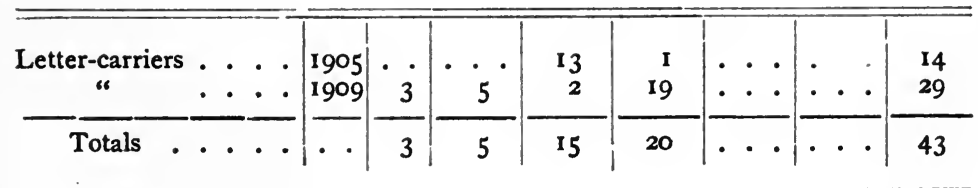




\section{TABLE XXVII}

CLASSIFIED EARNINGS OF CERTAIN WAGR-EARNERS IN IOWA, 1905, 1907, AND 1909 -Concluded

\begin{tabular}{|c|c|c|c|c|c|c|c|c|}
\hline Occupation. & 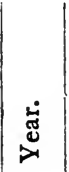 & 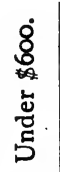 & 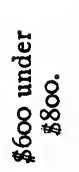 & 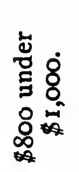 & 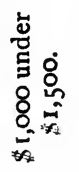 & 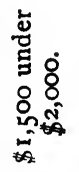 & 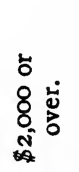 & 营 \\
\hline 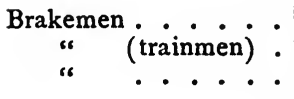 & $\begin{array}{l}1905 \\
1907 \\
1909\end{array}$ & $\begin{array}{l}3 \\
. \\
.\end{array}$ & $\stackrel{9}{9}$ & ${ }_{6}^{9}$. & $\begin{array}{l}2 \\
\cdot . \\
4\end{array}$ & 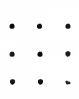 & $\begin{array}{l}\cdot \\
\because . \\
\end{array}$ & $\stackrel{23}{i_{3}}$ \\
\hline . • . & . & 3 & 12 & I5 & 6 & . . & . . . & 36 \\
\hline
\end{tabular}

\begin{tabular}{|c|c|c|c|c|c|c|c|c|c|c|}
\hline $\begin{array}{c}\text { Conductors } \\
\text { "6 }\end{array}$ & 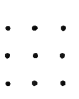 & $\begin{array}{l}. \\
: \\
.\end{array}$ & $\begin{array}{l}1905 \\
1907 \\
1909\end{array}$ & 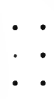 & 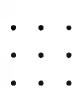 & $\begin{array}{l}\text { I } \\
\text { I } \\
3\end{array}$ & $\begin{array}{r}13 \\
9 \\
10\end{array}$ & $\begin{array}{l}4 \\
3 \\
6\end{array}$ & 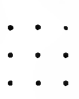 & $\begin{array}{l}18 \\
13 \\
19\end{array}$ \\
\hline Totals & . & . & - . & - . & . . & 5 & $3^{2}$ & 13 & . . & 50 \\
\hline
\end{tabular}

\begin{tabular}{|c|c|c|c|c|c|c|c|c|c|c|c|}
\hline $\begin{array}{c}\text { Engineers } \\
\text { "6 }\end{array}$ & $\dot{0} \cdot \dot{ }$ & $\dot{\cdot}$ & 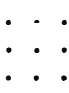 & $\begin{array}{l}1905 \\
1907 \\
1909\end{array}$ & $\begin{array}{l}2 \\
. \dot{ } \\
\cdot\end{array}$ & $\begin{array}{l}3 \\
. \\
\cdot .\end{array}$ & $\begin{array}{r}14 \\
2 \\
3\end{array}$ & $\begin{array}{l}\text { 16 } \\
\text { I3 } \\
27\end{array}$ & $\begin{array}{l}\text { i6 } \\
19\end{array}$ & $\begin{array}{l}\cdot \dot{\cdot} \\
\dot{1}\end{array}$ & $\begin{array}{l}35 \\
31 \\
50\end{array}$ \\
\hline Totals & . & . & . • & . . & 2 & 3 & 19 & $5^{6}$ & 35 & I & 116 \\
\hline
\end{tabular}

\begin{tabular}{|c|c|c|c|c|c|c|c|c|c|c|c|c|}
\hline $\begin{array}{c}\text { Firemen } \\
\text { “ }\end{array}$ & $\begin{array}{l}\cdots \\
\dot{ }\end{array}$ & & 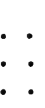 & $\dot{\circ}$ & $\begin{array}{l}1905 \\
190 \% \\
1900\end{array}$ & $\begin{array}{r}4 \\
\text { I } \\
. \quad .\end{array}$ & $\begin{array}{c}8 \\
\cdot 2\end{array}$ & $\begin{array}{l}5 \\
2 \\
5\end{array}$ & $\cdot \begin{array}{l}5 \\
7\end{array}$ & 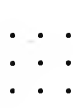 & $\begin{array}{ll}\cdot & \cdot \\
. & \cdot \\
\cdot & \cdot\end{array}$ & $\begin{array}{r}17 \\
8 \\
14\end{array}$ \\
\hline Tota & & . & - • & . • & & 5 & IO & 12 & 12 & $\cdot \cdot$ & $\cdot \cdot$ & 39 \\
\hline
\end{tabular}

\begin{tabular}{|c|c|c|c|c|c|c|c|c|c|c|c|c|}
\hline $\begin{array}{c}\text { Trainmen } \\
\text { "6 }\end{array}$ & $\dot{.}$ & & $\because$ & $\begin{array}{l}\dot{\bullet} \\
\dot{\cdot} \\
\dot{\cdot}\end{array}$ & $\begin{array}{l}1905 \\
1907 \\
1909\end{array}$ & $\begin{array}{r}3 \\
. \\
.\end{array}$ & $\begin{array}{c}10 \\
2 \\
. \quad .\end{array}$ & $\begin{array}{l}8 \\
7 \\
. \quad .\end{array}$ & 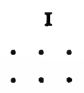 & 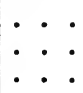 & 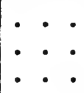 & $\begin{array}{r}22 \\
9 \\
. \quad .\end{array}$ \\
\hline Total & & . & . . & . & . . & 3 & 12 & I 5 & I & . . . & . . & $3 I$ \\
\hline
\end{tabular}

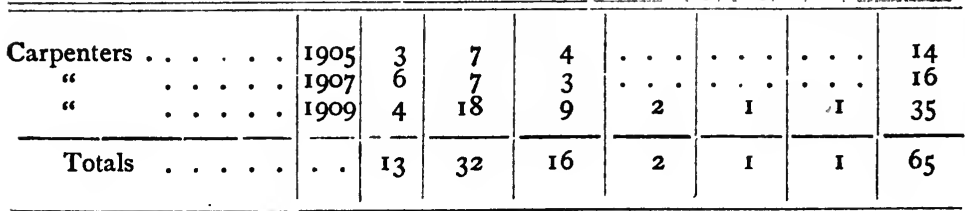


TABLE XXVIII

SUMMARY TABLE OF CLASSIFIED INCOMES OF CERTAIN KANSAS WAGE-EARNERS, AND CLASSIFIED EARNINGS OF CERTAIN IOWA WAGE-EARNERS

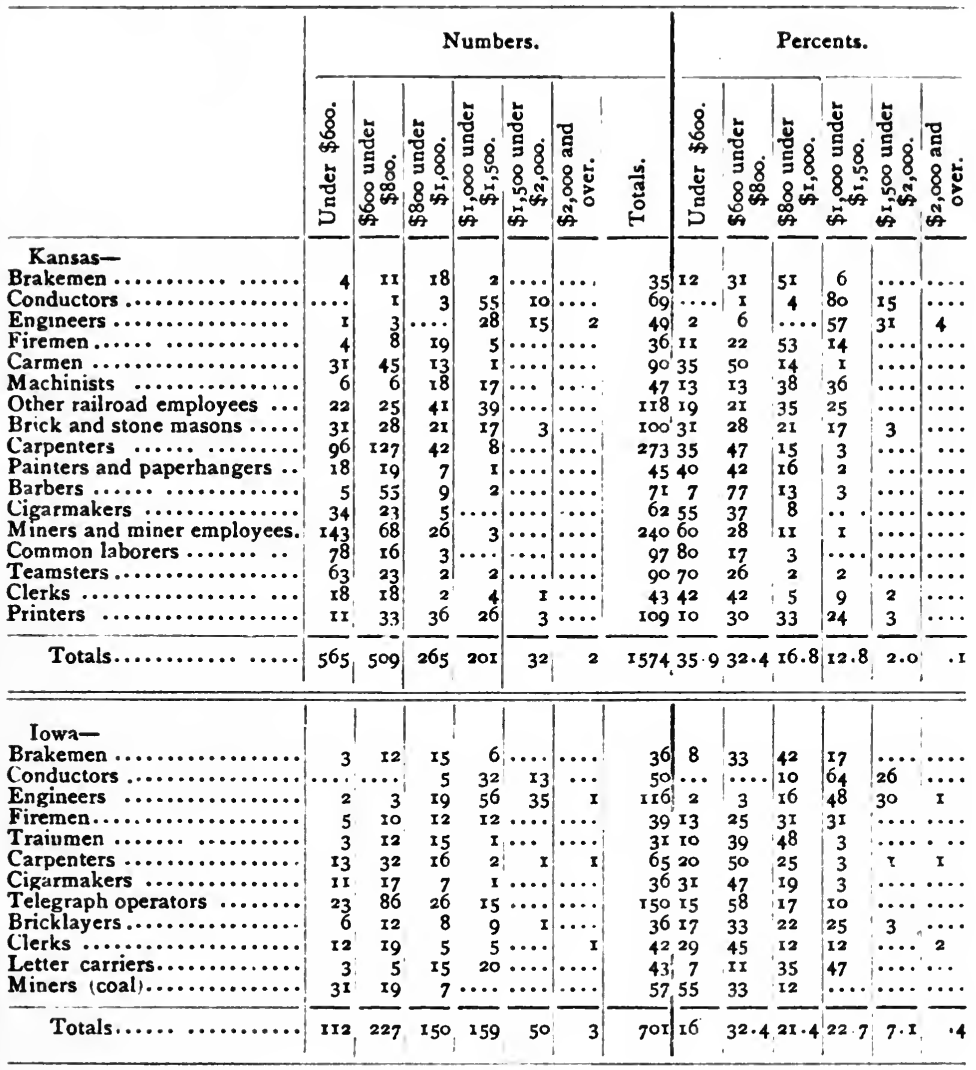

states. First, the Kansas returns, being almost exclusively from union men, have no determinable relation to the condition of the unorganized workers. Second, it is probably the more intelligent and the better-paid laborers who reply to such questionnaires as these states have circulated. Third, the cases are too few for any one year and occupation to be 
trustworthy as a basis of generalization. ${ }^{1}$ Fourth, the figures for Iowa are surprisingly at variance with the results both of the 1905 Census of Manufactures and of the study by the federal Labor Bureau in I90r, both of which show for that state average earnings considerably lower than those for the nation as a whole. ${ }^{2}$ These tables, therefore, depict wages too high to be considered quite representative.

While not, at first blush, as desirable as compilations of annual compensation, the statistics of quarterly earnings of the members of labor organizations, published by New York State, by virtue of the fact that they automatically make allowance for unemployment, are far preferable to any of the other regularly available data. During the year, there is variation from season to season, the building trades, for example, being burdened by idleness to a greater extent in the first three months than in the third, this phenomenon manifests itself in the regularity with which the average pay for the third quarter exceeds that for the first, except when such unusual happenings as the famous Clothing Strike in the fall of rgro interrupt the ordinary course of events. Nevertheless, within bounds, these New York returns can be considered a fair indication of the distribution of annual earnings among the union workingmen of the Empire State.

1 Not all the replies received by these states in the years under discussion have been used in making the summaries. Many occupations were represented in but one year, or by less than five persons in each year. These have been omitted, as a class entitled "miscellaneous" would not represent the same group of crafts from year to year.

2 Census of Manufactures, 1905, pt. iv, p. 670, shows average weekly earnings of males sixteen years and over in factories to be \$Ir.I6 for nation and \$10.48 for Iowa, which ranked thirty-fourth among the states for average earnings of men, p. 672. Eighteenth Annual Report of the Commissioner of Labor, p. 366, shows annual earnings of heads of families to have averaged $\$ 62$ I for the United States, \$5II for Iowa. 


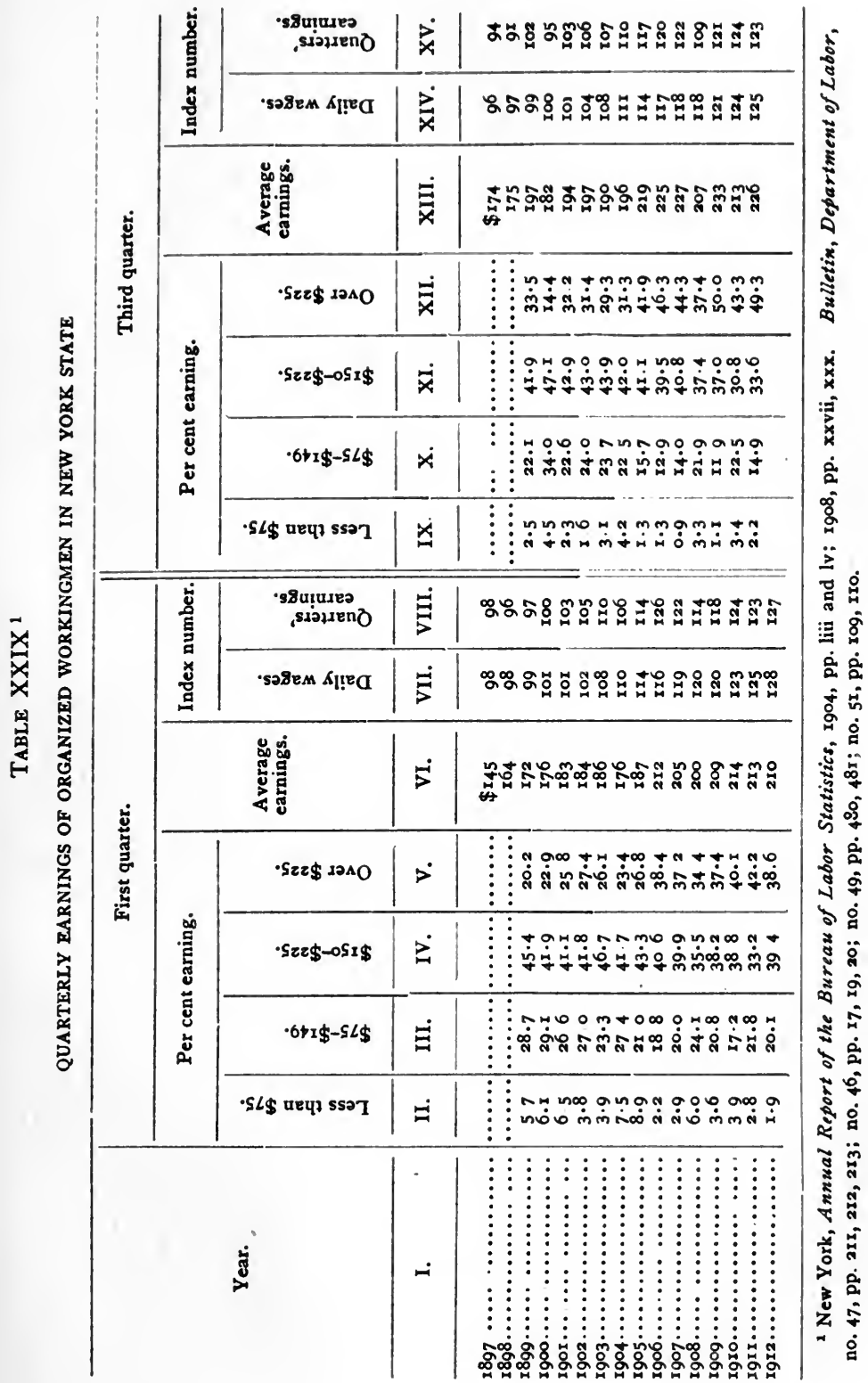


Table XXIX would seem to indicate that, both in average and in distribution, the compensation of union workingmen in New York is tending on the whole to improve. ${ }^{1}$ That, with one exception, for each of the last six quarters on record, more than forty per cent of these men have earned at least $\$ 225$, does not necessarily lead to the conclusion that over forty per cent are receiving as much as $\$ 900$ per annum nor does it inevitably follow from the table that, as a rule, the remuneration of between twenty and twenty-five per cent falls below $\$ 600$ a year: the income of each individual is more or less subject to fluctuation, he may be in one group this season, and in another the next. Neither must these figures be interpreted as applicable to the entire laboring force of New York State, for they relate only to union men. If, however, one assumes that employers consistently seek, in time of business dullness, to lay off the more inefficient hands first, then it is not unreasonable to hold that forty per cent or more of the organized male workers in New York enjoy incomes of at least $\$ 900$, and that well up toward twenty-five per cent do not earn as much as $\$ 600$.

The fact that a large proportion of the men employed in the telephone business possess, of necessity, more or less skill arouses the expectation that their wages are rather higher than those in most industrial occupations. Table $\mathrm{XXX}$ shows this to be the case. Judging by their monthly pay, seventeen per cent of these men receive less than $\$ 600$ per year, about fifty-six per cent earn $\$ 600$ but under $\$ 960$, and the remaining twenty-seven per cent get $\$ 960$ or more, three per cent enjoying at least $\$ 1,500$. These figures cover practically the entire public telephone industry in the United States, and include all males employed, no criterion of their ages being furnished.

${ }^{1}$ Money earnings, conf., p. 274, note. 
TABLE XXX ${ }^{1}$

MONTHLY RATES OF WAGES OF MALES IN THE TELEPHONE INDUSTRY, FOR A PAY ROLL PERIOD IN 1908

\begin{tabular}{|c|c|c|}
\hline I. & II. & III. \\
\hline Monthly rate of pay. & Number of males. & Per cent. \\
\hline Under $\$ 25 \ldots \ldots \ldots \ldots$ & 336 & 2.15 \\
\hline$\$ 25$ liut under $\$ 50 . . . \ldots$. & 2,333 & 14.99 \\
\hline $50 "$ " $60 . . . \ldots$ & 2,782 & 17.90 \\
\hline $60 "$ " $70 \ldots \ldots \ldots$ & 2,970 & 19.09 \\
\hline $80 \ldots \ldots$. & 3, OI 1 & 19.33 \\
\hline 80 " " $90 . \ldots \ldots$ & 1,385 & 8.91 \\
\hline $90 "$ " $100 . . . .$. & 1,325 & 8.51 \\
\hline 100 " " $125 \ldots \ldots \ldots$ & 909 & 5.84 \\
\hline 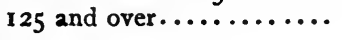 & 512 & 3.28 \\
\hline Totals ............. & 15,563 & 100.00 \\
\hline
\end{tabular}

In 1902, it will be remembered, the Census Bureau investigated Central Electric Light and Power Stations. In the report were published the classified wages of 18,878 of the employees, presumably all men. Since at that time the industry maintained, altogether, some twenty-six thousand wage earners, the sample was probably quite representative. ${ }^{2}$ Of these men, nearly 46 per cent were given less than $\$ 2.00$ per diem or a maximum of $\$ 626$ for the year, unless they were employed seven days to the week; about as many more were paid $\$ 2.00$ but less than $\$ 3.00$, leaving but eight per cent to be remunerated with three dollars or more, the full time equivalent of from nine to eleven hundred dollars a year, depending on the number of holidays and Sundays not worked.

${ }^{1}$ Investigation of the Telephone Companies, pp. 294, 298, 300, compiled.

2 Special Census Report on Central Electric Light and Power Stations, pp. I16, II7, I32, I33. 
TABLE XXXI ${ }^{1}$

WAGES OF EMPLOYEES OF CENTRAL ELECTRIC LIGHT AND POWER STATIONS, 1902

\begin{tabular}{|c|c|c|}
\hline I. & II. & III. \\
\hline Daily wages. & Men. & Per cent. \\
\hline Under $\$ 1 \ldots \ldots \ldots \ldots \ldots$ & 362 & 1.9 \\
\hline$\$ 1.00-\$ 1.24 \ldots \ldots \ldots \ldots \ldots$ & 990 & 5.2 \\
\hline $1.25-1.49 \ldots \ldots \ldots \ldots$ & 1,613 & 8.5 \\
\hline $1.50-1.74 \ldots \ldots \ldots \ldots$ & 3,380 & 17.9 \\
\hline $1.75-1.99 \ldots \ldots \ldots \ldots$ & 2.314 & 12.3 \\
\hline $2.00-2.24 \cdots \ldots \ldots \ldots \cdots$ & 4,089 & 21.7 \\
\hline $2.25-2.49 \ldots \ldots \ldots \ldots \ldots$ & 1,807 & 9.6 \\
\hline $2.5^{0}-2.74 \ldots \ldots \ldots \ldots$ & 1,899 & 10.1 \\
\hline $2.75-2.99 \ldots \ldots \ldots \ldots$ & 823 & 4.4 \\
\hline $3.00-3.24 \cdots \cdots \cdots \cdots \cdots$ & 832 & 4.4 \\
\hline $3.25-3.49 \ldots \ldots \ldots \ldots \ldots$ & 309 & 1.6 \\
\hline $3.5^{0}-3.74 \ldots \ldots \ldots \ldots \ldots$ & IgI & 1.0 \\
\hline 3.75 and over $\ldots \ldots \ldots \ldots$ & 269 & 1.4 \\
\hline Totals ............ & 18,878 & 100.0 \\
\hline
\end{tabular}

In the same year, 1902, the Census Bureau investigated also the Mines and Quarries of the United States and published a table showing the classified wages of the $58 \mathrm{r}, 728$ male employees of all the incorporated companies. Among these wage earners were some II 857 boys under sixteen years of age. Of all males occupied in the mines and quarries, 42.8 per cent were receiving less than $\$ 2.00$ per day, 45 per cent $\$ 2.00$ but less than $\$ 3.00$, and the remaining 12.2 per cent $\$ 3.00$ or more. Of the anthracite coal miners, 62.7 per cent were paid at a per diem rate less than $\$ 2.00$, and 84.8 per cent less than $\$ 2.50$; in the bituminous mines the corresponding percents were respectively 33.0 and 73.8. Unemployment is such a large factor in

${ }^{1}$ Special Census Report, Central Electric Light and Power Station, p. 60 ; the figures cover all wage-earners save those classed as miscellaneous occupations in 80 per cent of the plants. 
curtailing the earning power of coal miners that it would be unsafe to base any estimate of annual compensation upon these daily wages. According to the figures in Tables XXV and XXVIII, over $8 \mathrm{r}$ per cent of the coal miners in the country were receiving, in I90 I, less than $\$ 600$ per annum, in Kansas, about 1905 , 60 per cent. The fact that the great Anthracite Coal Strike of 1904 and the joint agreements have probably raised the rates of pay above those shown in Table XXXII, is another reason for refusing to build much upon this report.

\section{TABLE XXXII 1}

DAILY WAGES OF THE EMPLOYEES OF INCORPORATED COMPANIES, MINES AND QUARRIES IN 1902

\begin{tabular}{|c|c|c|c|}
\hline I. & II. & III. & IV. \\
\hline \multirow{2}{*}{ Daily wages (rate). } & \multicolumn{3}{|c|}{ Per cents. } \\
\hline & All minerals. & $\begin{array}{l}\text { Anthracite } \\
\text { coal. }\end{array}$ & $\begin{array}{l}\text { Bituminous } \\
\text { coal. }\end{array}$ \\
\hline 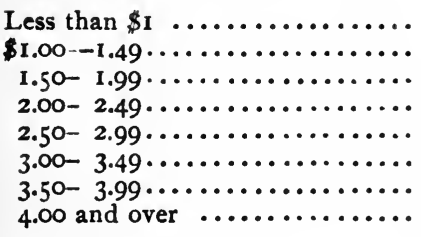 & $\begin{array}{r}2.8 \\
13.6 \\
26.4 \\
31.7 \\
13.3 \\
7.2 \\
3.9 \\
1.1\end{array}$ & $\begin{array}{r}9.1 \\
21.6 \\
32.0 \\
22.1 \\
7.1 \\
4.6 \\
2.6 \\
.9\end{array}$ & $\begin{array}{r}1.4 \\
7.1 \\
24.5 \\
40.8 \\
17.2 \\
6.6 \\
2.1 \\
. \quad 3\end{array}$ \\
\hline Number of men...$\ldots \ldots \ldots \ldots$ & 581,728 & $69,69 \mathrm{I}$ & 280,638 \\
\hline
\end{tabular}

The statistics of distribution of wages and earnings so far presented have been drawn mainly from the groups of manufacturing, transportation, and mining, but in the totals of the Eighteenth Anmual Report of the Commis-

${ }^{1}$ Census, Mines and Quarries, 1902, p. 96. 
sioner of Labor, ${ }^{1}$ were included some returns from the branches of industry known as trade, and domestic and personal service; moreover, data from a few agricultural laborers were given place. Although there seems to be no recent and extensive government study of the earnings of professional men, some information is available. In the first place, the salaries of school teachers in cities having a population of 8,000 or more have been classified under the direction of the late Carroll D. Wright for the National Education Association. Some of the results of this work have been compressed into the following table:

\section{TABLE XXXIII ${ }^{2}$}

SALARIES OF MALE TEACHERS IN PUBLIC SCHOOLS IN CITIES OF 8,000 OR OVER, 1905

\begin{tabular}{|c|c|c|c|}
\hline I. & II. & III. & IV. \\
\hline \multirow{3}{*}{ Salary. } & \multicolumn{3}{|c|}{ Per cents. } \\
\hline & \multirow{2}{*}{$\begin{array}{l}\text { High school } \\
\text { teachers. }\end{array}$} & \multicolumn{2}{|c|}{ Elementary school. } \\
\hline & & Principals. & Teachers. \\
\hline Under $\$ 600 \ldots \ldots \ldots \ldots \ldots \ldots$ & & & \\
\hline$\$ 600$ under $800 \ldots \ldots \ldots \ldots \ldots$ & $\begin{array}{r}2.15 \\
12.84\end{array}$ & $\begin{array}{r}4.20 \\
10.67\end{array}$ & $\begin{array}{l}19.31 \\
13.20\end{array}$ \\
\hline 800 " $1,000 \ldots \ldots \ldots \ldots \ldots$ & 15.28 & 14.18 & 12.26 \\
\hline $1,000 \quad$ “ $1,200 \ldots \ldots \ldots \ldots \ldots$ & 17.95 & 10.13 & 12.47 \\
\hline $1,200 \quad ، \quad 1,500 \ldots \ldots \ldots \ldots \ldots$ & 19.66 & 15.22 & 17.09 \\
\hline $1,500 \quad$ “ $2,000 \ldots \ldots \ldots \ldots \ldots$ & 18.79 & 20.73 & 25.67 \\
\hline 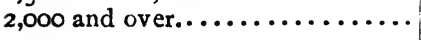 & 13.33 & 24.81 & .... \\
\hline Totals $\ldots \ldots \ldots \ldots \ldots \ldots$ & 100.00 & 100.00 & 100.00 \\
\hline $\begin{array}{l}\text { Number. } . \ldots \ldots \ldots \ldots \ldots \ldots \\
\text { Average salary. } \ldots \ldots \ldots \ldots \ldots\end{array}$ & $\begin{array}{l}2,874 \\
\$ 1303\end{array}$ & $\begin{array}{r}2,378 \\
\$ 1542\end{array}$ & $\begin{array}{r}1,492 \\
\$ 1161\end{array}$ \\
\hline
\end{tabular}

1 Tables XXIV and XXV.

${ }^{2}$ Report on Salaries, Tenure and Pensions of Public School Teachers in the United States, pp. 17-22. 
While this summary is doubtless accurate enough, it by no means represents the earnings of all male teachers in the United States; a glance at the reports of the Commissioner of Education will convince any one that the masters of district schools receive very low wages. Further, since the Census does not furnish the numbers of secondary school instructors and of elementary principals and teachers in the United States, it is impossible to know the sizes of the groups represented by these figures of salary distribution. It is, however, a surprising fact that only $\mathrm{I} 3.33$ per cent of the high-school teachers, a large proportion of whom are presumably well-educated men, are drawing salaries of $\$ 2,000$ or more.

The Census of Religious Bodies, 1906, shows the average salary of ministers of all denominations to have been $\$ 663$, but gives no idea of the distribution of these remunerations. ${ }^{1}$ The mean for the Methodist Episcopal Church was \$8I2, considerably above the general average. The various Conferences of this denomination publish Annual Minutes in which are recorded the salary of each minister and, if the church owns such a building, the rental value of the parsonage. The rgro minutes of ten fairly typical conferences were selected, and the incomes of the I,504 connected ministers noted. Including the worth of these parsonages, the annual remuneration of 30.9 per cent of these men was less than $\$ 600$, of 34.6 per cent $\$ 600$ but under $\$ I, 000$; 78.7 per cent of them received less than $\$ \mathrm{I}, 200$, and but 4.6 per cent, as much as $\$ 2,000$. In view of the fact that the mean pay of the Methodist ministers was found by the Census to be over twenty per cent higher than the average compensation of all clergymen, in Table XXXIV is exhibited a better distribution of incomes than would be found among the entire 108,000 members of this profession.

${ }^{1}$ Vol. i, pp. $94-97$. 
TABLE XXXIV

INCOMES OF 1504 METHODIST EPISCOPAL MINISTERS IN 1910

(Salary plus rental value of parsonage)

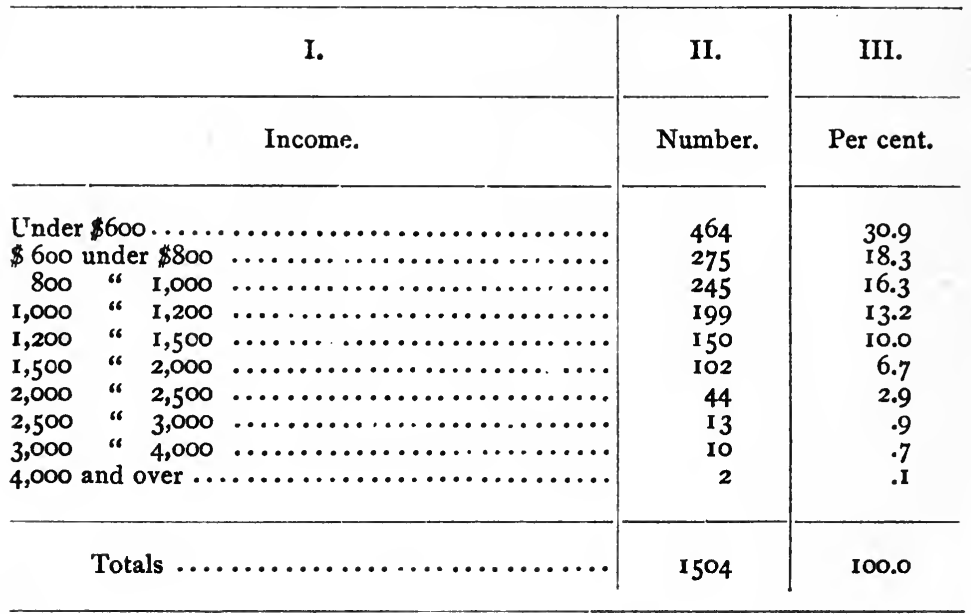

One great field of endeavor remains untouched. ${ }^{1}$ True, Table XXV shows the classified annual earnings of agricultural laborers, but it throws no light upon the incomes of the five million, seven hundred thousand farm families. This lack is partially relieved by the Census of Agriculture which classifies farms according to the value of their products not fed to live stock.

1 There are no reliable statistics of the incomes of physicians, but Dr. Taylor, of Philadelphia, estimated that 100,000 of them "average $\$ 1,000$ a year; $20,000, \$ 2,000$ per annum; $8,000, \$ 3,000 ; 5,000, \$ 5,000$; I,500, $\$ 10,000$; $200, \$ 20,000$; I50, $\$ 25,000$; $100, \$ 30,000$; and 50 physicians average $\$ 45,000$ a year." "Dr. Shrady, of New York, places the annual average income of 100,000 physicians at from $\$ 800$ to $\$ \mathrm{I}, 000$. He says that two or three physicians in New York make over $\$ 100,000$ each year; five or six range from $\$ 50,000$ to $\$ 60,000$, fifty from $\$ 25,000$ to $\$ 30,000$." Editorial, The American Medical Compend, March, 1904, vol. $\mathrm{xx}$, no. 3 , p. 76 . 
TABLE XXXV'

FARMS CLASSIFIED BY THE VALUE OF PRODUCTS NOT FED TO LIVE STOCK, I 899

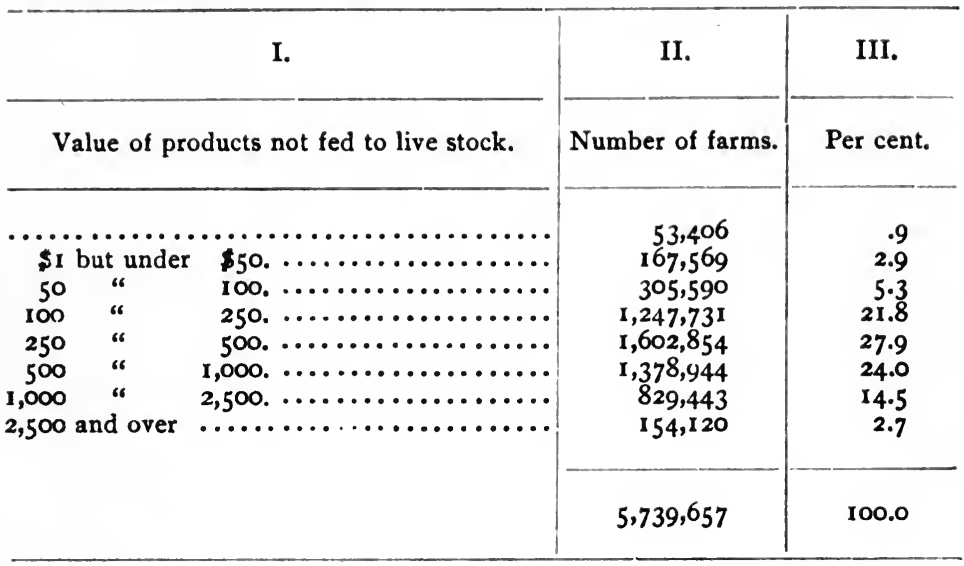

As has been pointed out, the exact distribution of incomes among farm families is not revealed by these figures, for the following reasons: first, in reckoning the value of the products of each farm, no allowance was made for purchases of feed, seed, and fertilizer; second, no deduction was made for rent; third, the wages paid to hired help were not accounted for; fourth, subsidiary incomes, either from rent of another farm owned by the proprietor of the place in question, or from other investments, or from labor performed outside, were not considered; fifth, as ideas on the cost of living in the country are even more vague than those as to the minimum of subsistence in cities, the welfare of these farm families cannot be compared with that of industrial households. What allowance should be made for errors from these opposing sources, it is impossible to say. However, that for a year when all crops except cotton were normal, the Census should show the total value of the products of 30.9 per cent of the farms to be under $\$ 250$, and of

1 Twelfth Census, vol. v, Agriculture, pt. i, pp. Ixiv, Ix. 
58.8 per cent to be less than $\$ 500$, is a safe indication that so far as money is a criterion, farming is not much, if any, more profitable than ordinary urban labor. ${ }^{1}$

The distribution of earnings among federal civil-service employees is shown in the following table. It is immediately patent that the government is a model employer.

\section{TABLE XXXVI ${ }^{2}$}

DISTRIBUTION OF COMPENSATION OF EMPLOYEES IN EXECUTIVE CIVIL SERVICE, 1907

\begin{tabular}{|c|c|c|}
\hline I. & II. & III. \\
\hline \multirow{2}{*}{ Earnings group. } & \multicolumn{2}{|c|}{ Males. } \\
\hline & Number. & Per cent. \\
\hline 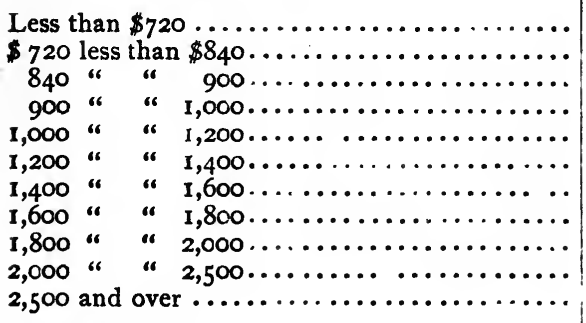 & $\begin{array}{r}28,812 \\
20,331 \\
10,299 \\
42,486 \\
32,696 \\
16,814 \\
8,760 \\
3,186 \\
2,911 \\
2,305 \\
1,872\end{array}$ & $\begin{array}{r}16.7 \\
11.8 \\
6.0 \\
24.7 \\
19.0 \\
9.8 \\
5.1 \\
1.9 \\
1.7 \\
1.3 \\
1.1\end{array}$ \\
\hline 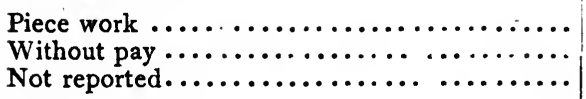 & $\begin{array}{r}1,136 \\
16 \\
429\end{array}$ & $\begin{array}{l}.7 \\
.7 \\
.2\end{array}$ \\
\hline & 172,053 & 100.0 \\
\hline
\end{tabular}

1 The large percents in the low-product groups cannot be entirely explained away by the errors which may have been incurred through the cropping system and similar schemes for cultivation in the South. For instance, a dozen small farms tilled by negroes may have been entered as having a valueless product, but their total output may have been listed as that of a farm .(plantation) producing a crop (cotton?) worth over $\$ 2,500$. (But there is a considerable percentage of farms 
The present chapter has attained such proportions that it may be well to summarize the conclusions.

I. Between four and five-tenths of the industrial families of the United States are entirely supported by the earnings of the father-husband, and the probability of a supplementary income is decreased, up to a certain unknown point, with every increase of the wages of the head of the household.

2. Wages in the factories of New York are vastly higher than at the close of the Civil War when measured by purchasing power, but very little higher in money.

3. Although state statistics show a tendency for money earnings to rise in recent years, an increase in real wages, as measured in terms of purchasing power of food, is doubtful. The Dewey Report and the 1905 Census of Manufactures show a probable decline in the average wages in this important branch of industry between 1890 and I904. Between I890 and 1900, the distribution of wages about the mean became distinctly less satisfactory, but in the years 1900 to 1904 there seems to have been a slight reversal of this tendency.

4. Since 1904 the state figures indicate an improvement of the money wages of men in factories. The extent of this improvement for the nation at large cannot be ascertained.

in each of the sections of the country, and also in the hands of each race, in the low-products group.) See Twelfth Census, vol. v, Agriculture, pt. i, pp. 1x, 1xx; also Abstract, pp. 222, 233.

Bulletin of the Twelfth Census, No. 94, Statistics of Employees, Executive Civil Service of the United States, p. 20. The persons referred to in this bulletin as "employees in the executive Civil Service" include practically all of the employees in the Civil Service of the United States with the exception of persons in the consular and diplomatic service, the postmasters, the clerks in postoffices not having free delivery, the mechanics and laborers in navy yards and naval stations, and the employees of the Isthmian Canal Commission employed on the Isthmus. 
5. The Census of Manufactures showed that, in 1904, 62. I per cent of the males, sixteen years of age or over, employed in factories were earning less than $\$ 12$ per week, the equivalent (full time) of $\$ 626$ or less annually. Six per cent were paid $\$ 20$ or more weekly, $\$$ I, 043 or more per year, full time.

6. The earnings of heads of families range higher than those of all males who have passed their sixteenth birthday.

7. In 1901, 47.56 per cent of the heads of industrial families, having an income less than $\$ \mathrm{I}, 200$ per annum, earned less than $\$ 600 ; 34.7 \mathrm{I}$ per cent received $\$ 600$ and less than $\$ 800 ; 5.40$ per cent, $\$ \mathrm{I}, 000$ or over. $\$ \mathrm{I}, 200$ seems to be almost the limit of wage earnings in most industrial occupations.

8. From 1903 to 1907 , in Kansas, about thirty-six per cent of mature organized workingmen received less than $\$ 600$, thirty-two per cent $\$ 600$ but less than $\$ 800$, fifteen per cent over $\$ \mathrm{I}, \mathrm{OOO}$.

9. In New York, in recent years, between seventeen and twenty-five per cent of the organized workingmen have earned less than $\$ 150$ per quarter, and over forty per cent have received $\$ 225$ or more.

Io. About seventeen per cent of the males in the telephone industry are paid under $\$ 600$ a year, fifty-six per cent $\$ 600$ but under $\$ 960$, nine per cent $\$ 1,200$ or over.

II. Nearly forty-six per cent of the men employed in central electric light and power stations, in 1902, were paid less than $\$ 2.00$ per day, and nearly another forty-six per cent $\$ 2.00$ but less than $\$ 3.00$.

I2. In the mines and quarries, in 1902, 42.8 per cent of the males employed earned less than $\$ 2.00$ daily, 45.0 per cent $\$ 2.00$ but less than $\$ 3.00$. Among these males, however, were II 857 boys under sixteen years of age (two per cent of all). 
I3. Male teachers in cities of at least 8,000 population receive salaries much above the wages in industry, over ninety per cent earning at least $\$ 600$, and nearly seventy per cent at least $\$ \mathrm{I}, 000$.

I4. Of Methodist Episcopal ministers, better paid than the average of all denominations, 30.9 per cent have incomes under $\$ 600$ per annum ; 34.6 per cent, $\$ 600$ but under $\$ 1,000 ; 4.6$ per cent, $\$ 2,000$ or over.

I5. According to the Census of Agriculture, in 1899, on 58.8 per cent of the farms of the United States the total value of all products not fed to live stock was under $\$ 500$; on 24 per cent the value was $\$ 500$ but under $\$$ r , 000.

r6. The United States government is more liberal with its compensation of ordinary labor than private employers.

The validity of any sweeping generalization which might be based upon these sixteen statements, would be subject to doubt. It is, however, desirable to describe the distribution of earnings among the largest possible group of men. The obtaining of this description involves an estimate. Estimates are at best only approximations of the truth, but they may, nevertheless, serve useful purposes. It is, however, essential to science that the real character of an estimate be appreciated; it is a guess, presumably a "wise guess", based upon a thorough consideration of the known facts, and subject to alteration as soon as new and better information is presented.

With this caution, it is not improper to submit the following estimate of the distribution of money earnings, first among the industrial people, that is, among males of at least sixteen years engaged in manufacturing, mining, and in some branches of trade, transportation, and personal service; and, second, among these industrial workers combined with ministers, agricultural laborers, and farm families. In the table, the third column gives the approximate num- 
ber of males sixteen years of age or over engaged in 1904 in the occupation or industry named in column I. The rest of the table was constructed as follows: taking "barbers and hair dressers", for example, the "a" in column II signifies that, on the whole, the best statistics covering men in this trade are to be found in Table XXV of this essay, which shows that about forty-two per cent of the barbers investigated in I90I earned less than $\$ 600$, about fiftyseven per cent $\$ 600$ but less than $\$ \mathrm{I}, 000$, and less than one per cent, $\$ \mathrm{I}, \mathrm{OOO}$ or over. Using these proportions and recording the results in round numbers, columns IV, V, and VI were filled in-forty-two per cent of I34,00o being 56,280 , for instance. The men engaged in manufacture could not be treated in exactly this way, as annual compensations are not available; the number of these persons earning less than \$12 per week was placed in column IV, the number receiving $\$ 12$ but less than $\$ 20$ in column V, and the number paid $\$ 20$ or over in column VI. The same process was used in distributing the "miners and quarrymen-not coal", except that, from the total number of miners and quarrymen, belonging in each column according to the census, was subtracted the number of coal miners in that column, approximately according to the Kansas distribution; thus the Census group of 582 ,000 was divided into two classes. The cost of living being lower outside than within cities, the number of agricultural laborers earning less than $\$ 400$ was placed in column IV, along with the number of farm families, or more strictly speaking, of farms, the products of which were valued at less than $\$ 500$. Corresponding changes were made in column V. With this explanation, the table should be intelligible. 
TABLE XXXVII

ESTIMATE OF THE DISTRIBUTION OF INCOMES PRIMARILY FROM LABOR

\begin{tabular}{|c|c|c|c|c|c|}
\hline I. & II. & III. & IV. & $\mathbf{V}$ & VI. \\
\hline Occupation or industry. & 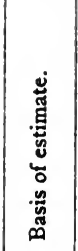 & 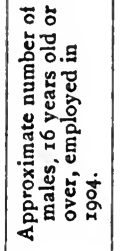 & 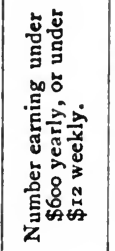 & 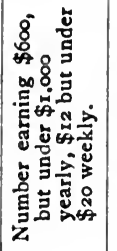 & 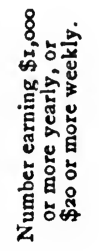 \\
\hline 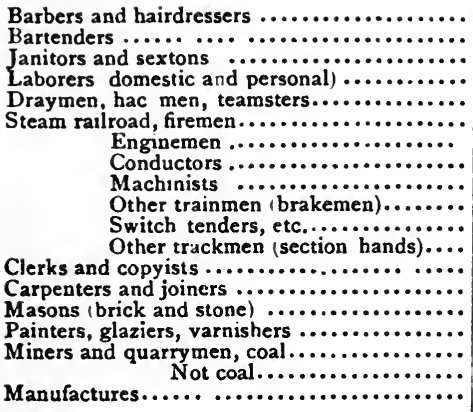 & $\begin{array}{l}\text { a. } \\
\text { a. } \\
\text { a. } \\
\text { a. } \\
\text { b. } \\
\text { b. } \\
\text { b. } \\
\text { b. } \\
\text { b. } \\
\text { c. } \\
\text { a. } \\
\text { c. } \\
\text { b. } \\
\text { b. } \\
\text { a. } \\
\text { b. } \\
\text { b. \&d. } \\
\text { e. }\end{array}$ & $\begin{array}{r}134,000 \\
95,000 \\
52,000 \\
2,691,000 \\
568,000 \\
55, \infty 00 \\
52,000 \\
40,000 \\
46, \infty 00 \\
107, \infty 00 \\
46, \infty 00 \\
289,000 \\
569,000 \\
645,000 \\
173,000 \\
294,000 \\
351,000 \\
231,000 \\
4,245,000\end{array}$ & $\begin{array}{r}56,000 \\
29,000 \\
31,000 \\
2,516,000 \\
360,000 \\
6,000 \\
1,000 \\
\ldots . \\
6,000 \\
13,000 \\
18,0610 \\
245,000 \\
132,000 \\
226,000 \\
53,000 \\
127,000 \\
210,000 \\
38,000 \\
2,664,000\end{array}$ & \begin{tabular}{|r|}
77,000 \\
65,000 \\
20,000 \\
175,000 \\
208,000 \\
41,000 \\
3,000 \\
2,000 \\
24,000 \\
88,000 \\
23,000 \\
44,000 \\
323,000 \\
400,000 \\
85,000 \\
161,000 \\
137,000 \\
167,000 \\
$1,325,000$
\end{tabular} & 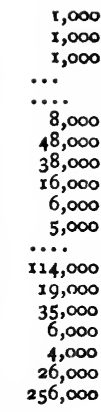 \\
\hline $\begin{array}{l}\text { Totals, industrial } \ldots \ldots \ldots \ldots \ldots \ldots \ldots \ldots \ldots \ldots \ldots \\
\text { Ministers } \ldots \ldots \ldots \ldots \ldots \ldots \ldots \ldots \ldots \ldots \ldots \ldots \ldots \\
\text { Agricultural laborers } \ldots \ldots \ldots \ldots \ldots \ldots \ldots \ldots \ldots \ldots \ldots \ldots \\
\text { Farm families } \ldots \ldots \ldots \ldots \ldots \ldots \ldots \ldots \ldots \ldots \ldots \ldots \ldots \ldots\end{array}$ & $\mid \begin{array}{l}\cdots \\
\text { g. } y . \\
\text { t. } x .\end{array}$ & $\begin{array}{r}10,683, \infty 00 \\
106,000 \\
3,129,000 \\
5,740,000\end{array}$ & $\begin{array}{r}6,731,000 \\
33,000 \\
2,597, \infty 00 \\
3,377, \infty 00\end{array}$ & $\begin{array}{r}3,368,000 \\
36,000 \\
532,000 \\
1,379,000\end{array}$ & $\begin{array}{l}584, \infty 00 \\
37,000 \\
\ddot{984,000}\end{array}$ \\
\hline Totals........ & $\cdots \cdots$ & $19,658, \infty 00$ & $12,73^{8}, 000$ & $5,3 \times 5, \infty$ & $x, 605, \infty 00$ \\
\hline
\end{tabular}

${ }^{1}$ The bases of the estimate are as follows:

a. Eighteenth Annual Report of the Commissioner of Labor, or in this essay, Table XXV.

b. Reports of the Kansas Bureau of Labor, or Table XXVIII.

c. Slight modification of the proportions in "a."

d. Census of Mines and Quarries-includes II,800 boys under sixteen years of age, Table XXXII.

e. Census of Manufactures, 1905, Table XXI.

f. Census of Agriculture, 1900, Table XXXV.

g. Table XXXIV.

$x$. In column iv are placed all farms the value of whose products, 
The reason for including in column III the approximate number of men employed in each branch of work in 1904, is the fact that at present the largest compilation of classified wage data is the Census of Manufactures for that year; the statistics showing earnings in other occupations relate to years on both sides of 1904. Doubtless it is inaccurate to combine figures for different dates, yet it has already been noted that the rise of compensation in manufactures between 1900 and 1904 was very slight, if it was not entirely imaginary; there is, moreover, no evidence of a considerable advance in other wages during this period. Consequently, it is probable that, including in the same table results of computations based on studies made in different years entails, in this case, no great error.

It requires little ingenuity to find faults in this summary table. For instance, among the "farm families" the Census enumerated about three hundred thousand establishments headed by women; the bases of some of the estimates

not fed to live-stock, was less than $\$ 500$; in column $v$ the number of farms producing to the value of $\$ 500$, but less than $\$ 1,000$; in column vi the number producing $\$ 1,000$ or more.

y. In column iv is placed the number earning less than $\$ 400$; in column v those earning $\$ 400$ but less than $\$ 1,000$. This is done that the difference in cost of living in urban and rural localities may be somewhat taken into account in a rough way.

As only Ioo agricultural laborers were included in the Bureau of Labor investigation, the basis for the distribution of the earnings of three million men may seem absurdly small. However, the average earnings of the 100 was $\$ 269$. An investigation of the Michigan Bureau of Labor in 1905, covering 5,922 farms in 1,210 towns, showed that farm hands worked an average of 8.5 months at a mean wage, including value of board, of \$23.II, or \$196 per year. (Michigan, Report Bureau of Labor, 1905, p. 347.) Doubtless there are many localities in the North where the earnings of agricultural labor are greater than this, but there are other communities where help, especially in the South, gets much less. So probably the distribution shown in the Bureau of Labor Report is substantially correct. 
are narrow; there is not an exact coincidence in the nomenclature of occupations between the various sources of statistics; the year I904 is long past; there is such a combination of wages and annual earnings in the data that there can be no strict line between the income groups; it is impossible to determine the distribution of yearly remuneration from that of weekly pay. On the other hand, except in the cases of manufacturing and mining, the estimate is based on the compensation of mature men-mostly heads of families, and, in some trades, members of labor unions; moreover, where wage statistics were used, it was impossible to make any legitimate allowance for unemployment. Most of these inaccuracies would tend to make the distribution of annual earnings, among males sixteen years or more of age, appear better than, in I904, it actually was.

In view of this consideration, and of the general harmony of the statistics presented in this chapter, it is reasonable to believe that, in I904, something over sixty per cent of the males at least sixteen years of age, employed in manufacturing, mining, trade, transportation, and a few other occupations associated with industrial life, were earning less than $\$ 626$ per annum, about thirty per cent were receiving $\$ 626$ but under $\$ 1,044$, and perhaps ten per cent enjoyed labor incomes of at least $\$ \mathrm{I}, \mathrm{OoO}$. If to these the agriculturists are added, sixty-five per cent fall in the lowearnings group, twenty-seven in the medium, and eight in the high. Suppose all the men engaged in gainful occupations in I904, but unaccounted for in this estimate, to have been paid \$I2 per week or more. This is manifestly impossible, yet, even upon such an assumption, fully onehalf of the adult males engaged in remunerative labor were rewarded that year with less than $\$ 626$. 


\section{CHAPTER VII}

\section{INCOMES FROM PROPERTY}

IN I900 the Census Bureau estimated the value of the total wealth of the United States at about eighty-eight and a half billion dollars, and in 1904 at just over one hundred seven billion. If, since that time, this rate of increase has been consistently maintained the riches of the nation were close to one hundred forty-three billion in I9ro and to one hundred fifty-six billion in I9I2. A large proportion of this wealth is productive, for instance, the farm lands, ${ }^{1}$ mines, quarries, factories, railways, telephones, telegraphs, and other forms of business property, and a large part of the residential real estate. Desirable as it would be to know the distribution of this income-yielding property, it is, as appeared in Chapter III, impossible even to approximate the number of individuals who possess it. There are, however, some hints as to the extent of ownership, which are well worth consideration.

On June 7, I9I I, the I,884 savings banks in the United States had 9,597, I 85 accounts, aggregating $\$ 4,2$ I $2,583,598$, an average of $\$ 438.93 .{ }^{2}$ It is a perfectly well-known fact that the number of individual depositors is less than the number of accounts, as well-to-do persons frequently have money in several institutions at the same time. On the other hand, one acquainted with such large savings banks

1 The advance figures of the census of rgro show an increase in value of farm lands from $\$ 13,058,008,000$ in 1900 to $\$ 28,386,770,000$ in 1910 .

2 American Year-Book for I9II, p. 303. 
as the Bowery, the Dime of Brooklyn, or the Williamsburgh, can confidently assert that the great mass of beneficiaries are working people. Thursday afternoon, for instance, is sometimes known as "Servant Girls' Day". In I9I0, there were eighty-seven savings banks in Connecticut with 575,9 I 3 depositors, of whom 492,773 , or 85.5 per cent, had balances of under $\$ \mathrm{I}, 000$ each; not less than $\$ \mathrm{I}, 000 \mathrm{but}$ less than $\$ 2,000$ was due to 54,669 persons, or 9.5 per cent; $\$ 2,000$ or more, to $28,74 \mathrm{I}$ individuals or five per cent of the depositors. This five per cent had total claims amounting to $\$$ IOI,544,660, the first eighty-five and a half per cent to $\$$ IOI,682,7 IO, the average of all accounts being $\$ 478.96$. $^{1}$ In the fiscal year ending June 30, 1910, the mutual savings banks in the United States paid their customers dividends averaging 3.92 per cent, the mean return in the stock savings banks was $3.5^{6}$ per cent. ${ }^{2}$ Some depositors make a practice of regularly drawing their " interest". It is thus apparent that, whatever allowance must be made for duplications among the owners of the nine and a half-million accounts, there is a large number of people, mostly of small means, who are regularly deriving some income from savings banks. The dividends due one individual may seldom be large, but they aggregate over $\$$ I I0,000,000 per annum.

Another form of saving is life insurance. Although the twenty-three million odd industrial policies are a form of thrift, they are not properly income-yielding investments, at least in the sense, that dividends do not accrue to their

${ }^{1}$ Report of the Bank Commissioners, State of Connecticut, for year ending Sept. 30, I910, p. II.

2 It should be noted that dividends are paid only on money actually in the bank on the dividend day, having been on deposit at least three months. Savings banks do not pay "interest on daily balances." In mutual savings banks all the earnings belong to the depositors. Stock savings banks are run for profit by corporations, which appropriate part of the earnings. Conf. Table XXXIX. 
owners. However, nearly seventy-three per cent of the $\$ 13,227,213,168$ of ordinary insurance carried, on some 6,954, I I9 policies, is "participating". In I9IO, the dividends paid to the holders of these policies amounted to $\$ 75,353,638$. Needless to say cash was not often directly given to the insured, but the amount of the profit was either deducted from the necessary premium, reserved against future obligations, or added to the value of the policy. Thus whatever of this sum was actually deducted from payments or used to increase principal is the equivalent of income to the policy holder. Insurance is therefore another form of property which yields a real, if individually small, income to literally millions of persons. ${ }^{1}$

Nearly as widely distributed as savings accounts and insurance policies is productive real estate. In I9IO, there were some 6,340,357 farms of which 2,622,34I were owned outright by the families that tilled them; another I,3II,364 mortgaged farms were occupied by the title holders; $2,349,254$ were worked by tenants and 57,398 by managers. ${ }^{2}$ How much of the $\$ 8,926,000$,000 gross agricultural products were imputable to the land and capital, and how much to the labor of the farmers and their help cannot be determined from the existing data. It is clear, however, that at least 3,933,705 persons, probably well up toward five million owned agricultural property, and since the value of these farms more than doubled in a decade, it is safe to conclude that the large majority receive incomes properly attributable to this real estate.

The I9Io figures for residential real estate are not yet published. As has been indicated, in 1900, nearly sixty-

${ }^{1}$ F. L. Hoffman, Quarterly Publications of the American Statistical Association, no. 95, vol. xii, Sept. I9I I, pp. 684, 735, 748.

2 Advance Statement of the Thirteenth Census, General Data on Agriculture. 
four per cent of the families not on the farms hired their tenements, and only 23.4 per cent owned their homes free of encumbrance. Of those who did hold title to their dwellings certainly most enjoyed a psychic income, and many an additional financial benefit, inasmuch as they did not pay rent. Subtract upkeep and taxes from the cost of accommodations of the same grade, and what remains is the income to the owner from his possession, nonetheless real because he does not calculate it in money. On the other hand, the 4,999,302 households hiring their quarters were, at least in the greater part, contributing to the property income of their landlords, but the number of these proprietors and the amount of their revenue is hidden. Here again is painfully apparent the impossibility of statistically treating the distribution of property incomes.

Not a bit more satisfactory is the information relating to the ownership of factories. Although the schedule of the r9io Census of Manufactures called for the number of "proprietors and partnership members, if a non-incorporated organization ", and of stockholders, if a corporation, the returns so far published give only 273,265 as the number of " proprietors and firm members" of the $268,49 \mathrm{I}$ establishments. ${ }^{1}$ Even if the total of the numbers of stockholders in the separate establishments was known, because of the infinite possibilities of duplications among the owners of the 69,50I incorporated plants, it would be as little representative of the true state of affairs as the data on the holders of railway and industrial securities discussed in Chapter III. Since allowance for the proper depreciation charges has been carefully avoided, and since no data is offered regarding the interest on funded debts, the Bureau of the Census is extremely careful to warn the world

${ }^{1}$ Census Bulletin, Manufactures: United States, p. 3. 
against drawing any conclusions as to profits in manufacturing.

Further citation of " near-facts" would be profitless, but it may be worth while to mention the light which may be gained from the tax lists. In I895, the New Jersey Bureau of Statistics of Labor and Industry published the following table:

TABLE XXXVIII 1

DISTRIBUTION OF ASSESSMENTS IN NEWARK, CAMDEN, JERSEY CITY, AND PATTERSON IN 1895

\begin{tabular}{|c|c|c|c|}
\hline I. & II. & III. & IV. \\
\hline Assessment. & Individuals. & Firms. & Corporations. \\
\hline$\$ 1,000-\$ 2,000 . \ldots \ldots \ldots \ldots \ldots \ldots$ & I 7,832 & 336 & 158 \\
\hline $2,000-\quad 3,000 . \ldots \ldots \ldots \ldots \ldots \ldots$ & I 1,033 & 220 & I 6 \\
\hline $3,000-4,000 . \ldots \ldots \ldots \ldots \ldots$ & 6,576 & $14^{0}$ & 85 \\
\hline $4,000-\quad 5,000 . \ldots \ldots \ldots \ldots \ldots \ldots$ & 3,838 & 82 & 73 \\
\hline $5,000-10,000 . \ldots \ldots \ldots \ldots \ldots$ & 5,596 & 240 & 169 \\
\hline $10,000-1_{5}, 000, \ldots \ldots \ldots \ldots \ldots \ldots$ & $x, 316$ & 97 & 97 \\
\hline $15,000-25,000, \ldots \ldots \ldots \ldots \ldots \ldots$ & 886 & 85 & 114 \\
\hline $25,000-50,000 . \ldots \ldots \ldots \ldots \ldots$ & $44^{\circ}$ & 72 & 105 \\
\hline $50,000-100,000 . \ldots \ldots \ldots \ldots \ldots$ & 163 & 36 & 85 \\
\hline \multirow[t]{2}{*}{100,000 and over $\ldots \ldots \ldots \ldots \ldots$} & $9 \mathrm{I}$ & 17 & IOI \\
\hline & $47,77 \mathrm{I}$ & 1,325 & I, 103 \\
\hline
\end{tabular}

The population of Newark, Camden, Jersey City, and Patterson, in I895, was found to be 559,$330 ; 8,492$ individuals, or I.5 per cent of the population, were believed, by the assessors, each to own at least $\$ 5$,000 worth of real and personal property. These persons probably belonged to not more than eight per cent of the families. The $47,77 \mathrm{I}$ possessors of at least $\$ \mathrm{I}, 000$ worth of assessable property were 8.54 per cent of the population and could hardly have repre-

${ }^{1}$ Report N. J. Bu. Stat. Lab. and Industry, 1895, p. 169. 
sented forty per cent of the families in the four municipalities.

New Britain, Connecticut, "the Hardware City", is a typical cosmopolitan industrial center. Its " Grand List" for ry ro showed $\$ 37,002,903$ of taxable property, of which $\$ 36,700,000$ was invested in land, houses, stores and their stocks, mills and factories, and manufacturing and mechanical operations. In this city an effort has been made to rate all wealth at its full market price, but in spite of the stringent Connecticut oath personalty seems to escape. Assuming that residential real estate yields income, the distribution of taxed values will correspond closely with the diffusion of tangible productive property. Inspection of the Grand List shows that 988 individuals, 2.25 per cent of the population, were assessed for upwards of $\$ 5,000 ; 2,364$ persons, 5.38 per cent of the inhabitants, for at least $\$ 2,000$ : and that 3,468 names were on the books as more than "polls". Perhaps one-eighth of the families in the city were worth $\$ 5,000$ or over, and one-third could command as much as an even thousand dollars.

Thase tax statistics from New Jersey and Connecticut are not cited as proof that approximately an eighth of the urban households of the United States are possessed of productive property to the value of $\$ 5.000$. The point is, first, that the number of families deriving any considerable income from the direct ownership of tangible wealth is exceedingly small, and second, that, because of the obvious failure to reach many forms of capital, the general property tax can offer no safe ground for inference as to the distribution of incomes. ${ }^{1}$

In 1892 and 1902 , the Tribune and the World published

I In New Britain not an individual reported money on hand or on deposit exceeding $\$ 100$, or ownership of stock liable to taxation. 
lists of American millionaires. On the first, there were 4,047 names and on the second 3,$045 ;^{1}$ but it is extremely difficult to believe that the number of such fortunes had actually decreased in the decade. The Financial Red Book of America, a volume apparently designed to facilitate soliciting, gives the names of over eighteen thousand " rich men".

The endeavor to determine the number of persons or of families enjoying incomes from the ownership of property cannot at present lead to a definite result. There are probably nine million individuals receiving some return on savings accounts, and upward of five million indirectly obtaining profit from participating life-insurance policies. About five million persons possess agricultural land, and perhaps as many more hold residential real estate. Approximately 270,000 proprietors own the unincorporated factories, but how many have invested in corporate securities is enigmatical. Tax lists show that the number of families having large amounts of wealth is small, but fail to give the clue to the diffusion of capital. Although it may be crudely stated that there are over eighteen thousand rich families in the country, this knowledge is of little value without some definition of "rich". There are probably more than four thousand millionaires. To attempt, therefore, to estimate the distribution of incomes from property would be absurd.

If it is impossible to determine the number of persons who own productive property, it is not quite so difficult to approximate the earning power of capital. "Seven trust companies in New York, with a total capitalization of \$25,375,000 , made during the period between November Io, I9I0, and December 2I, I9II, \$10,436,300, or 45.I per

${ }^{1}$ Watkins, American Economic Association, 1907, vol. 8, pp. I43, I45. 
cent. These figures are taken from the reports on those dates and include the dividends paid by these companies in that interval." ${ }^{1}$ Thus the annual rate of return on the par value of stock was close to forty per cent. It must be remembered, however, when considering banking institutions of any class that the "surplus" really is capital. Even with this reservation, the fact that the thirty-six New York City Trust Companies in 1909 earned a net income of 36.88 per cent of their capitalization, and paid dividends averaging 22.49 per cent shows well what great return may be reaped by investors in a comparatively " sure thing ". 2

Other enterprises are not so highly remunerative. During the year ending June 30 , I9I0, for example, no dividend was paid on over thirty-three per cent of the stock of the railways, and less than four per cent on thirty-nine per cent. The successful companies seem to distribute from six to eight per cent. ${ }^{8}$ In Table XXXIX is shown the capital stock, funded debt, dividends and interest, or net corporate income, for various forms of enterprise. The return to stockholders varies from 1.62 per cent of the par value of capitalization in the case of independent telephone companies to 14.52 per cent for private banks and a rate higher still for express companies; but in almost every industry there are some concerns which earn even less than the interest on the bonds. The most important item in the table is the last, the returns of the 270,202 corporations reporting to the Commissioner of Internal Revenue. The average rate of interest on bonds paid by commercial con-

${ }^{1}$ Wall Street Journal, 16 Jan., I912.

2 Compiled from reports in the Financial Age, 3 Jan., 19ro, pp. 34, 35, vol. xxi.

3 Statistics of Railways for year ending June 30, 1910, p. 56. 


\begin{tabular}{|c|c|c|c|c|c|c|}
\hline & $\dot{x}$ & 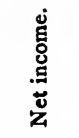 & 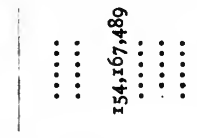 & $\vdots \vdots$ & $:: \vdots:: \vdots$ & 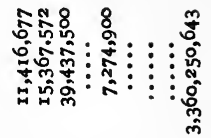 \\
\hline & $\ddot{x}$ & 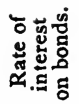 & 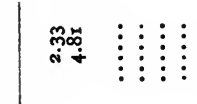 & : $\vdots$ & 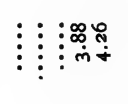 & 实 \\
\hline & $\stackrel{\Xi}{J}$ & 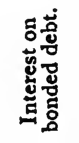 & 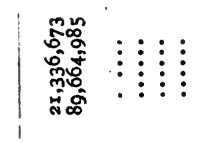 & $\vdots \vdots$ & 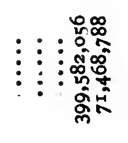 & 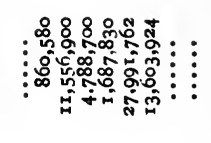 \\
\hline & $\dot{5}$ & 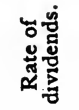 & 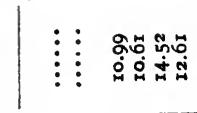 & 边 & 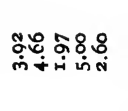 & 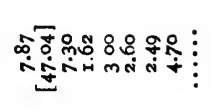 \\
\hline 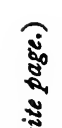 & $\dot{s}$ & 咅 & 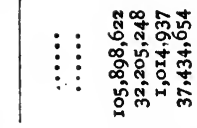 & 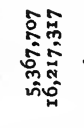 & 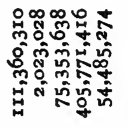 & 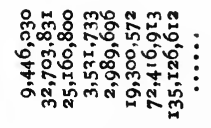 \\
\hline 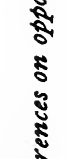 & $>$ & 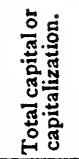 & 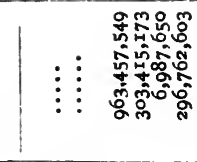 & 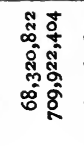 & 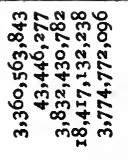 & 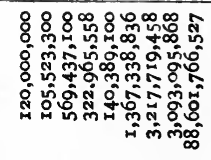 \\
\hline 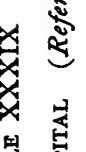 & $\dot{2}$ & 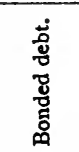 & 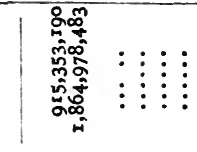 & $\vdots \vdots \vdots$ & $\vdots \vdots \vdots \vdots$ : & 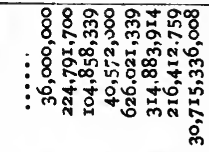 \\
\hline 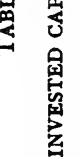 & $\Xi$ & 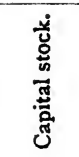 & 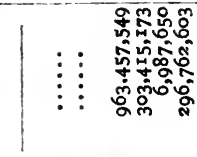 & 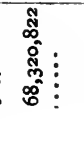 & 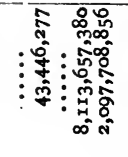 & 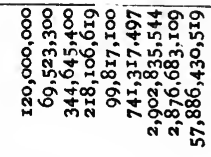 \\
\hline 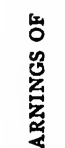 & $\dot{\Xi}$ & 它 & 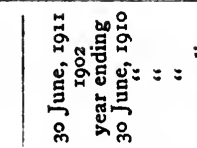 & 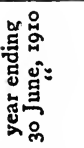 & = 옳: 영 & 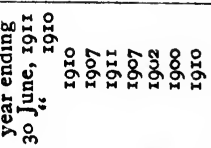 \\
\hline & 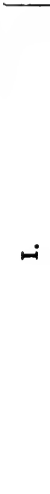 & 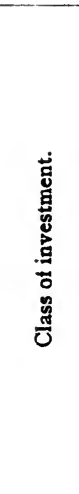 & 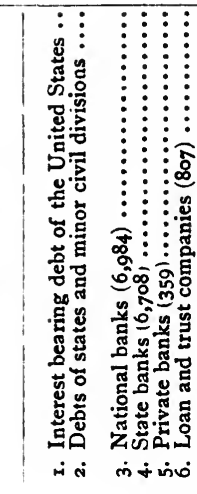 & 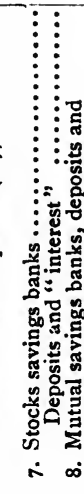 & 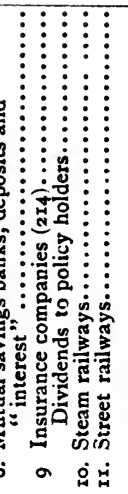 & 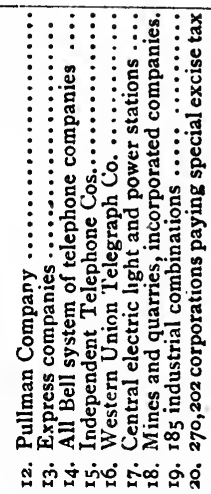 \\
\hline
\end{tabular}


cerns, as shown by the figures in the table, is 3.99 per cent; at this rate the bonds of these corporations would pay in the course of the year $\$ 1,225,541,900$. Adding this sum to the official net income gives $\$ 4,585,893,000$, or a return of 5.176 per cent on the total capitalization of $\$ 88,601,-$ $766,527 . .^{1}$ These figures are particularly significant in that the receipts of companies due to intercorporate holdings of stock are deducted in finding the net revenue; thus the in-

1 It may be interesting to note that the census estimate of the total wealth of the United States in 1900 was $\$ 88,517,306,775$. Statistical Abstract of the United States for I910, p. 589. Compare this with the nominal capital of the corporations' in $1910, \$ 88,601,766,527$.

\section{REFERENCES FOR TABLE XXXIX:}

I. American Year-Book, p. 27.

2. Wealth, Debt, and Taxation, Twelfth Census, pp. I42, 221 .

3. Report of the Comptroller of the Currency, I9I0, p. 334.

4, 5, 6. Ibid., p. 831. (Includes only those paying dividends on stock.) 7. Ibid., pp. $743,783,831$.

8. Ibid., pp. 739, 783 .

9. F. L. Hoffman, Quarterly Publications of the American Statistical Association, no. 95, vol. xii, pp. 732, 735, 751. (Includes fortythree mutual companies. "Admitted assets" entered in table as capital stock. Only 66 of the companies paid dividends, their rate being 8.48 per cent on the $\$ 23,842,44$ I stock.)

I0. Statistics of Railways, 1910, pp. 50, 51, 55, 57.

II. Street Railways, Special Census Report, 1907, pp. I02, 103.

12. Preliminary Abstract of Statistics of Common Carriers, I9I , p. 55 .

13. Special Report, Interstate Commerce Commission, Express Companies, 1910, pp. 15, 30. (Includes $\$ 24,000,000$ extra dividend by Wells, Fargo Co.)

14. American Year-Book, I9II, p. 549.

15. Special Census Report, Telephone Companies, 1907, pp. 57, 59. (Excludes inter-company payments.)

I6. American Year-Book, I9I I, p. 548.

17. Special Census Report, Central Electric Light and Power Stations, p. 6r.

18. Census Report, Mines and Quarries, 1902, p. 88.

19. Census of Manufactures, 1900, pt. i, p. lxxix.

20. Report of the Commissioner of Internal Revenue, I9II, p. 75. 
come as reported by the Commissioner of Internal Revenue has eliminated duplications.

Even with this excellent information as to the earnings of all the corporations doing business in the United States, it is impossible to find the net earnings of capital, because the necessary data are lacking for such important industries as farming, the renting of real estate, store-keeping, and a host of minor enterprises. For example, in the field of agriculture, there is no way of determining how much of the $\$ 8,900,000,000$ worth of produce in 1909 was due to the labor of the farmer, and how much to his land and implements; and, indeed, the value of some of the farm products reappears in the dividends of such corporations as the great milk companies. Moreover, the capitalization of corporations is no criterion of the actual investment.

A triple conclusion is, therefore, confirmed at every turn. First, that the number of individuals enjoying incomes from capital is unknown, though large; second, that the total national income from capital cannot be accurately determined; third, that as a consequence, it is futile to attempt to describe, in any way definite enough to be valuable, the distribution of incomes from property in the United States. ${ }^{1}$

1 The same may be said of incomes from the right of private property. From the Surrogates' books in New York, and the Probate records in Connecticut, it would be possible to compile a table showing the distribution of inheritances by size, but to-day the state of New York keeps no record of either the number or the aggregate value of estates assessed, much less anything more detailed. 


\section{CHAPTER VIII}

\section{Summary and Conclusion}

For the intelligent discussion of many social questions which are pressing more and more their claim upon public attention, a clear concept of the distribution of incomes among the individuals and families of the United States is necessary. The more elaborate and exact this concept is, the more useful it may become; but, for many purposes, all that is requisite is a simple presentation of the number of adult males or of families in each income group, the groups being definite and preferably limited in range to one hundred dollars, at least as far as the thousand-dollar mark. It would be well, if possible, to draw a distinction between rewards of labor, and returns from the ownership of property; inheritance and gifts, being essentially transfers of revenue from capital, are not particularly important in this connection. Although a great mass of wage statistics is at hand, most of this material is of little value in determining annual earnings; but there have been some important compilations of the classified weekly pay of factory operatives in the United States as a whole, and in the commonwealths of Massachusetts, New Jersey, Kansas, and Wisconsin, as well as the unique reports from labor organizations in New York, and several excellent special studies, notably the Eighteenth Annual Report of the Bureau of Labor, and the returns to the Kansas and Iowa questionnaires. These publications, however, treat only the compensation of labor; and there is scant basis for an investigation of the division 323] 
of the earnings of capital. The incomplete success, which has attended the serious attempts to treat statistically the distribution either of incomes or of earnings in the United States, is due to this surprising lack of data.

It has not been the aim of this essay to solve the problem, but rather to depict the deplorable dearth of information on a subject so vital to the welfare of the country. Some conclusions have been reached, but they must be considered tentative, and accepted, if at all, only with their qualifications. It is important to note that somewhere between four and five-tenths of the industrial families of the United States are dependent for support entirely upon the father-husband; probably the same proportion does not hold for agricultural districts. In the second place, the purchasing power of pay in manufactures in New York has nearly doubled since the close of the Civil War; presumably this is also true of other industries, and of other states. On the other hand, in the last twenty years, the gain of REAL wages, among factory operatives, and among trade-unionists in New York, seems to have been slight. A consideration of the evidence found in all the available reports, leads to the conclusion that in 1904, and probably at the present time, at least half of the males aged sixteen or more, engaged in gainful occupations were earning less than $\$ 626$ a year. This statement cannot be considered a description of the distribution of incomes, for there is sometimes a wide difference between the earnings of the head of a household and its actual receipts. ' It neither refutes nor confirms the belief of Dr. Spahr, that in I892, i I,000,000, or seven-eighths of the American families, had incomes under $\$ 1,200$, but it is interesting to note that of the nineteen and a half-million mer tabulated in Table XXXVII, hardly one-twelfth were annually earning more than $\$ \mathrm{I}, 000$ (or \$r,043). Another striking fact is that the grand list 
of New Britain showed about one-eighth of the families having property worth at least $\$ 5,000$, exactly the proportion found by Dr. Spahr for New York State eighteen years before, and by him used as the foundation of his estimate. ${ }^{1}$

This estimate of at least one-half the adult males earning less than $\$ 626$ per annum is in perfect harmony with the results of Professor Nearing, ${ }^{2}$ provided his rather questionable deduction for unemployment be ignored. The important point to note here, however, is that in this essay account was taken roughly of agricultural laborers and of farm families, which gives the conclusion a far greater scope than that confined to industrial workers north of the Mason-Dixon line and east of the Rockies.

The remarkable similarity between the results of Spahr for the United States and of Leroy-Beaulieu for Paris has been noted; for this country 87.5 per cent of the families were said to have incomes under $\$ 1,200$, for Paris 89.02 under 7,000 francs $(\$ \mathrm{I}, 35 \mathrm{I})$. The earnings of men are of course not comparable with the family incomes of Parisians. Taking only the industrial workers in Table XXXVII, it is noticable that about sixty-three per cent were earning less than $\$ 626$ per year and over ninety per cent less than $\$ \mathrm{r}, 044$. In Paris the incomes of nearly fortynine per cent of the families were under 2, 100 francs $(\$ 505.30)$, and of 74.60 per cent under 3,500 francs $(\$ 675 .-$ 50). Although there seems to be no way of accurately comparing the two scales, as the earnings of industrial workingmen are being contrasted with the incomes of ALL the families of the French capital, the situation in America appears to be no worse.

${ }^{1}$ Vide supra, opening pages of chapter $\mathrm{v}$.

2 Vide supra, p. 75. 
It appeared that, in 1905, over one-half, probably sixtenths of the Prussians belonged to families having incomes under 2,700 M. ( $\$ 643)$. As 56.48 per cent of the inhabitants of this principality lived in households no member of which annually received $900 \mathrm{M}$. (\$2I4), it is safe to conclude that money wages are far higher in the United States than in Germany. Similarly, so far as money alone is concerned, the Americans are certainly better off than the English, for it will be remembered that the "inhabited house tax" showed that about four-fifths of the English families were in tenements the rental value of which would indicate an income under $\mathfrak{f}_{\mathrm{I} 4 \mathrm{O}}(\$ 68 \mathrm{I})$.

In all these comparisons no attention has been paid to price levels in the different localities or at the different periods of time. Without fuller knowledge, it is folly to compare the welfare of American workers with that of people of other countries, for the statistics are absolutely incomparable; earnings of men and family incomes are essentially distinct, mental traits vary from place to place, purchasing power of money constantly changes, and, finally, the conclusions as to wages are all uncertain. This much, however, can be said, the money earnings of American men, seem to be at least equal to the money incomes of families in France, England, and Prussia.

Vague as must be these conclusions as to the earnings of labor, even less is known of incomes from property. More than ten million individuals are doubtless recipients of small dividends from savings banks and life insurance companies, probably over eight million enjoy returns from agricultural and residential real estate, but how many are interested in incorporated companies none can tell. Eighteen thousand men are rich enough to have their names entered in the Financial Red Book, and over four thousand were millionaires in 1892 . But these bits of information are no 
sound basis for studying the distribution of incomes from property.

The conclusion of the whole matter is this. Knowledge of the distribution of incomes is vital to sane legislative direction of progress. In a form definite enough for practical use, this knowledge does not exist. No time should be wasted in obtaining this knowledge. 


\section{CHAPTER IX}

\section{A Suggestion}

FROM the foregoing discussion two facts should be clear: first, that up to the present time there has been no satisfactory study of the distribution of incomes in the United States; and, second, that the material for such a study is not now available. It remains to suggest a simple and effective method of obtaining this material.

A well-administered, progressive income tax might easily furnish the clue. But it must be remembered that taxes are not imposed for the purpose of gathering sociological data. ${ }^{1}$ Neither the English nor the Prussian imposts allow of precise translation into terms of distribution of incomes, and the Comptroller of the State of New York cannot even say how many estates are assessed in a given year. Suppose that the Constitutional amendment now apparently approaching ratification be adopted, and a tax imposed under it, if the policy of tapping at the source be adopted, the records will completely fail to reveal the distribution of incomes. Taxation, therefore, promises slight aid.

Obviously the simplest expedient is to ask at the census what the income of the family, or of its head and of each contributing member, is. But this plan is probably imprac-

1 The income-tax law of Wisconsin, the first assessment under which is not complete at this writing, exempts $\$ 800$ to individuals. Thus a summary of the assessments will not show the distribution of incomes; other deductions will make even more difficult the estimate of distribution. 
ticable at the present time. It is so "inquisitorial" that it is "un-American". Such a question would certainly encounter resentment, and, perhaps, misrepresentation if not defiance. Moreover, it is probable that many of the very rich do not know exactly what their income is; the poor are very frequently unable to say what they have earned in the course of the year. So it seems that, at least for the present, the direct question is not feasible.

There is nothing original in the plan about to be proposed except the technique of its application. But in the technique lies the secret of accuracy of approximation to the facts.

First, the families of the United States may be divided into two large classes, farm families, and non-agricultural families. Sixty-four per cent of the agricultural households own their homes, nearly sixty-four per cent of the non-farm families rent their dwellings. ${ }^{1}$ As to the farm families, the recent Census of Agriculture called for the following information concerning the individual farms in r909:

I. Total value of products at the farm.

2. Amount spent in cash for farm labor (exclusive of housework).

3. Amount spent for feed for domestic animals.

4. Amount spent for fertilizers.

5. Estimated value of house rent and board furnished farm laborers in addition to cash wages.

6 . Whether the operator owned and rented other farm land.

7. Total value of products not fed to live stock.

It will readily be seen that if, from the value of products not fed to live stock, were subtracted the amount spent in 
cash for labor, the cost of purchased feed and fertilizers, and the value of the accommodations furnished to the help, there would be left a fairly close approximation to the income of the farm family. If the next Census include one additional question, calling for the rent paid by those who hire their places, or for the interest on mortgages, the information for determining the net return to the household from working the farm will be complete. ${ }^{1}$ The revenues thus determined should be classified according to size, and, also, with regard to whether the operator holds other land from which he derives income, owns simply the farm he tills, or hires the property. Since the additional question concerning rent or interest on mortgage is no more "inquisitorial" than those already asked and answered concerning the value of products, the value of the farm, and the amount of mortgage indebtedness, it should prove itself practical. A classification of the net returns calculated on this basis would not, to be sure, give an exact summary of the distribution of incomes among the agricultural families, for some farmers have other investments than land, but it would approach much more closely to the facts than any knowledge available at present, and would be a valuable first step.

The problem of the distribution of incomes among the non-agricultural families can probably be best approached through the rental values of their living accommodations. To ask the rent paid for a hired dwelling, or the rental value of an owned home, is hardly more bold than to inquire whether the house is mortgaged. An intelligent agent could form an accurate opinion of the correctness of the

${ }^{1}$ For real accuracy a further deduction should be made for seeds, insurance, depreciation of implements, and part of taxes. The plan aims at the simplest way of securing approximately correct results, without cumbering the schedules. 
reply. An ignorant laborer could answer this question much more easily than one calling for a knowledge of his year's earnings. This inquiry could, therefore, easily be carried on the Population Schedule without incurring much risk of misrepresentation or of opposition. The interpretation of the returns in terms of the distribution of incomes, although not so simple as may at first appear, is entirely feasible.

It is well known that as the incomes of families increase the average expenditure for rent rises in absolute amount but decreases relatively. For example, in 1890 , there were collected in St. Louis budgets which showed the total earnings and the rents paid by 254 households. As these were industrial people, the error is probably not great in treating the total earnings as the family income. On this basis the following table has been compiled:

TABLE XL ${ }^{1}$

RELATION OF RENT TO FAMILY EARNINGS, ST. LOUIS, I 890

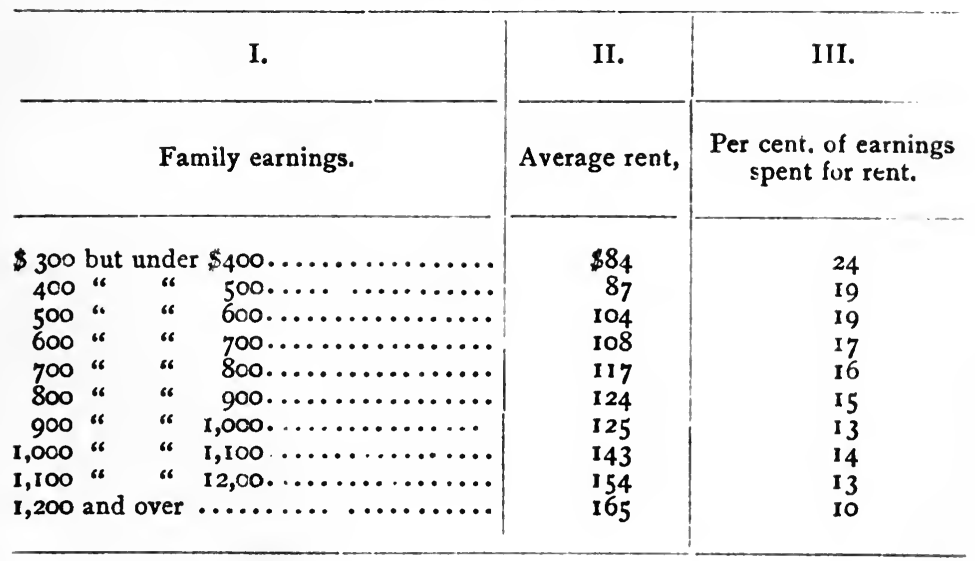

1 Compiled from the individual returns in the Annual Report of the Missouri Bureau of Labor Statistics, I890, pp. 400 et seq. 
In addition to the facts in Table XL the distribution of rents among these families is known to be that in Table XLI.

\section{TABLE XLI}

DISTRIBUTION OF RENTS AMONG 254 ST. LOUIS FAMILIES, 1890

\begin{tabular}{|c|c|c|}
\hline & I. & II. \\
\hline & Rent. & Number of families. \\
\hline $\begin{array}{l}\$ 50 \text { but under } \\
70 \text { “ “ } \\
90 \text { “ “ } \\
110 “ \\
130 \% \\
150 \text { “ “ “ } \\
170 \text { “ “ } \\
160 \text { and over }\end{array}$ & 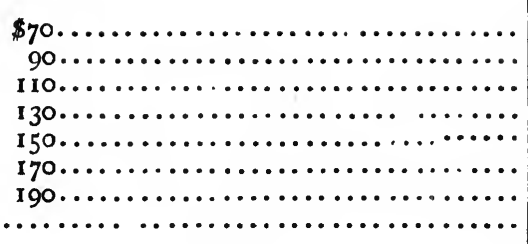 & $\begin{array}{r}4 \\
34 \\
74 \\
70 \\
37 \\
16 \\
9 \\
10\end{array}$ \\
\hline
\end{tabular}

Is it permissible to reason thus? If the income is $\$ 500$ and under $\$ 600$ the proportion spent for rent is 19 per cent, if the earnings are $\$ 600$ but under $\$ 700,17$ per cent. Thus the proper rent to be paid from a $\$ 600$ income is about 18 per cent of $\$ 600$ or $\$ 108$. From the table it appears that 38 rents are less than $\$ 90 ; 74$ are between $\$ 90$ and $\$$ I Io; eighteen-twentieths of 74 is 66 ; therefore about I04 rents are under $\$ 108$, or the earnings of 104 families are less than $\$ 600$. The answer is to be found in the following table which compares the number in each earnings group as thus computed, and as actually enumerated. 
TABLE XLII

DISTRIBUTION OF INCOMES AMONG 254 ST. LOUIS FAMILIES AS COMPUTED FROM RENTALS BY FIRST METHOD, AND AS ENUMERATED

\begin{tabular}{|c|c|c|c|}
\hline I. & II. & III. & IV. \\
\hline \multirow{2}{*}{ Income group. } & \multicolumn{2}{|c|}{ Number in group. } & \multirow{2}{*}{$\begin{array}{l}\text { Difference } \\
\text { II-III. }\end{array}$} \\
\hline & Computed from rents. & Enumerated. & \\
\hline 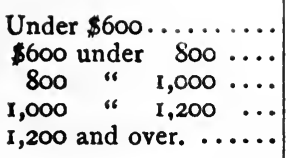 & $\begin{array}{r}104 \\
57 \\
30 \\
33 \\
30\end{array}$ & $\begin{array}{l}65 \\
86 \\
54 \\
22 \\
27\end{array}$ & $\begin{array}{l}+39 \\
+29 \\
+24 \\
+11 \\
+\quad 3\end{array}$ \\
\hline Totals ........... & 254 & 254 & $\begin{array}{l}+53 \\
-53\end{array}$ \\
\hline
\end{tabular}

The experiment makes it clear that this method of estimating the distribution of incomes from the classified returns of rents is not at all satisfactory. The trouble probably lies in the tendency for rents to concentrate on multiples of six and twelve.

Is there not a law of the relation of rent to income? Certainly. If, in the case of these particular St. Louis families the total earnings be measured on the $\mathrm{X}$ axis, and the rent paid on the $\mathrm{Y}$ axis, and if the origin is at $(0,0)$, then the law of the relation of rent to income is $\mathrm{y}=0.055 \mathrm{x}+$ 74.30. ${ }^{1}$ In other words, to find the normal rent for a given income, multiply the earnings by 0.055 and add $\$ 74.30$. Applying this law, and using the actual rents of the individual families, instead of interpolating as above, the following approximation of the distribution of incomes is obtained :

${ }^{1}$ Calculated by the method of moments. 
TABLE XLIII

DISTRIBUTION OF INCOMES AMONG 254 ST. LOUIS FAMILIES, AS COMPUTED BY MEANS OF THE EQUATION OF REGRESSION

\begin{tabular}{|c|c|c|c|c|}
\hline I. & II. & III. & IV. & v. \\
\hline \multirow[b]{2}{*}{ Income group. } & \multirow[b]{2}{*}{$\begin{array}{l}\text { Corresponding } \\
\text { rents. }\end{array}$} & \multicolumn{2}{|c|}{ Number in group. } & \\
\hline & & $\begin{array}{l}\text { Computed } \\
\text { from rents. }\end{array}$ & $\begin{array}{c}\text { Enumera- } \\
\text { tion. }\end{array}$ & $\begin{array}{l}\text { Difference } \\
\text { III-IV. }\end{array}$ \\
\hline 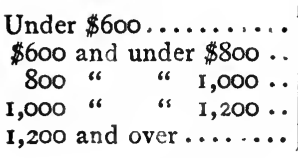 & $\begin{array}{l}\text { Under } \$ 107.30 \ldots \\
\$ 107.31-118.30 . \\
118.31-129.30 . \\
129.31-140.30 . \\
\text { 140.3I and over. }\end{array}$ & $\begin{array}{l}76 \\
46 \\
60 \\
20 \\
52\end{array}$ & $\begin{array}{l}65 \\
86 \\
54 \\
22 \\
27\end{array}$ & $\begin{array}{l}+11 \\
+40 \\
+6 \\
+2 \\
+25\end{array}$ \\
\hline Totals $\ldots \ldots \ldots$ & ...... & 254 & 254 & $\begin{array}{r}+42 \\
-42\end{array}$ \\
\hline
\end{tabular}

This estimate is not much preferable to the other. By the first method fifty-three cases were misplaced, by the second, forty-two.

Probably the best approximation can be obtained by the method exemplified in Table XLIV. After shuffling thoroughly the cards on which were entered the rents and family earnings of these 254 St. Louis families, a random sample was taken without particular reference to size. It included 124 cards. Sorting showed the distribution of rents and incomes to be that recorded in Table XLIV, A. Section B of the table was next computed to show the percent distribution of earnings among the families in each rent group. The first line in section $\mathrm{C}$ gives the distribution of the families in the rent groups as determined by the enumeration. Using the percents in section $B$, these numbers in the first line of section $\mathrm{C}$ were apportioned among the various income groups for 
TABLE XLIV

COMPUTATION OF DISTRIBUTION OF INCOMES FROM DISTRIBUTION OF RENTS, 254 ST. LOUIS FAMILIES

A. Numerical Distribution of Rents and Incomes in Sample

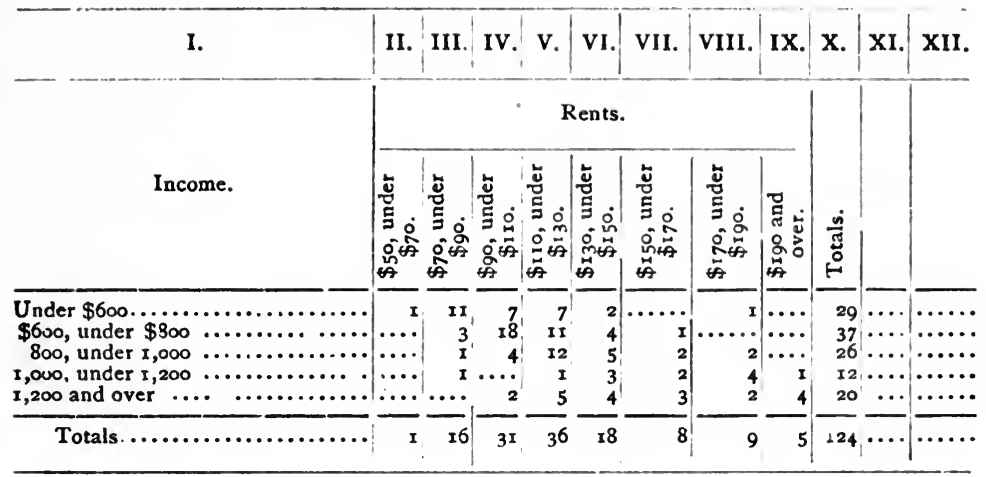

B. Per cent Distribution of Incomes in each Rent Group

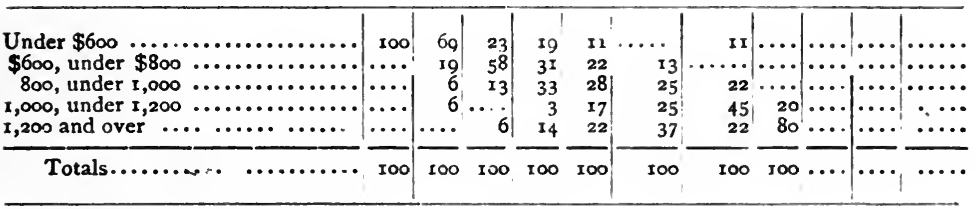

C. Numerical Distribution of Incomes among 254 St. Louis Families Computed from Actual Distribution of all Rents and from B, Compared with Results of Actual Enumeration

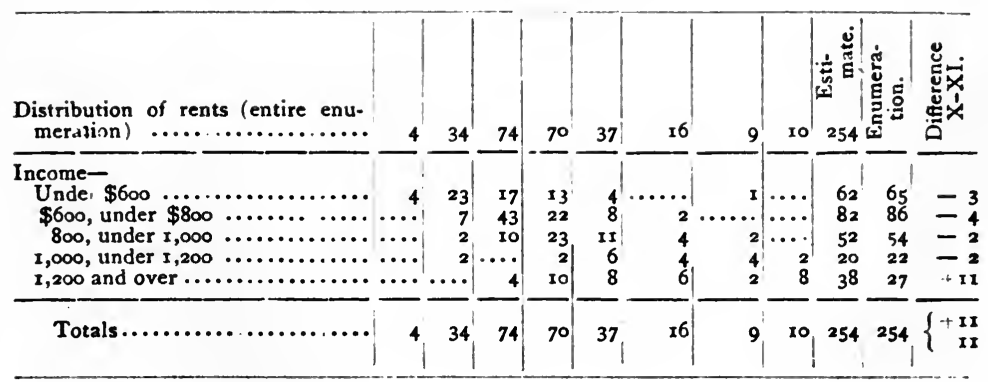




\section{TABLE XLV}

COMPUTATION OF DISTRIBUTION OF INCOMES FROM THE DISTRIBUTION OF RENTS, 39I NEW YORK FAMILIES

A. Numerical Distribution of Rents and Incomes in Sample

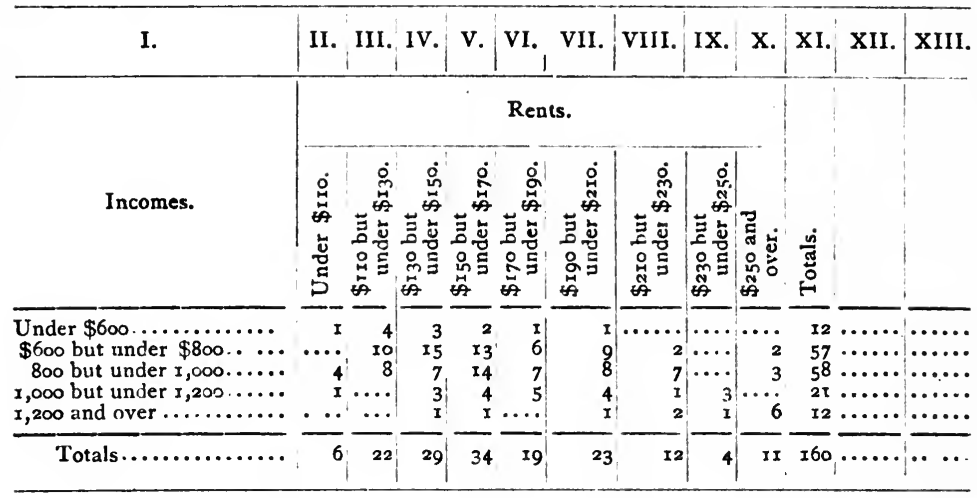

B. Per cent Distribution of Incomes in Each Rent Group

\begin{tabular}{|c|c|c|c|c|c|c|c|c|c|c|c|c|}
\hline 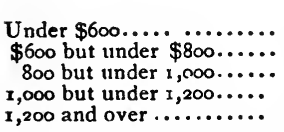 & $\begin{array}{r}x 7 \\
67 \\
67 \\
\cdots\end{array}$ & $\begin{array}{r}18 \\
45 \\
37 \\
\cdots\end{array}$ & $\begin{array}{l}10 \\
53 \\
24 \\
10 \\
3\end{array}$ & $\begin{array}{r}6 \\
3^{8} \\
41 \\
12 \\
3\end{array}$ & $\begin{array}{r}5 \\
32 \\
37 \\
26 \\
\ldots \ldots\end{array}$ & $\begin{array}{r}4 \\
39 \\
35 \\
18 \\
4\end{array}$ & $\begin{array}{r}17 \\
58 \\
8 \\
17\end{array}$ & $\begin{array}{r}\cdots \cdots \\
\cdots \\
\cdots \\
75 \\
25\end{array}$ & $\begin{array}{r}\cdots \\
18 \\
27 \\
\cdots \\
55\end{array}$ & $\begin{array}{c}\quad \\
\cdots \\
\cdots \\
\cdots \\
\cdots\end{array}$ & $\begin{array}{c}\ldots \ldots \\
\ldots \ldots \\
\ldots \ldots \\
\ldots \ldots\end{array}$ & $\begin{array}{ll}\cdots \cdots \\
\cdots \cdots \\
\cdots \cdots \\
\cdots \cdots\end{array}$ \\
\hline & 100 & 100 & 100 & 100 & 100 & 100 & 100 & 100 & 100 & . & & \\
\hline
\end{tabular}

C. Numerical Distribution of Incomes among 391 New York City Families Computed from Actual Distritution of Rents and from B, and Compared with Results of Enumeration

\begin{tabular}{|c|c|c|c|c|c|c|c|c|c|c|c|c|}
\hline $\begin{array}{l}\text { Distribution of rents (en- } \\
\text { tire enumeration } \ldots \ldots .\end{array}$ & r7 & $5 I$ & $70^{+}$ & 100 & $4 \mathrm{I}$ & 49 & 24 & $x_{3}^{\prime}$ & 26 & 391 & : & 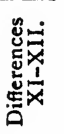 \\
\hline $\begin{array}{l}\text { Incomes- } \\
\text { Under } \$ 600 \ldots \ldots \ldots \ldots \\
\$ 600 \text { but under } \$ 800 \ldots . \\
800 \text { but under } r, \infty 00 \ldots . \\
x, \infty 00 \text { but under } 1,200 \ldots \ldots \\
r, 200 \text { and over } \ldots \ldots \ldots \ldots \ldots\end{array}$ & $\begin{array}{r}3 \\
\ldots \\
\text { iI } \\
3 \\
\ldots\end{array}$ & $\begin{array}{r}9 \\
23 \\
19 \\
\ldots \ldots \\
\ldots \ldots\end{array}$ & $\begin{array}{r}7 \\
37 \\
17 \\
7 \\
2\end{array}$ & $\begin{array}{r}6 \\
6 \\
38 \\
4 \mathbf{1} \\
12 \\
3\end{array}$ & $\begin{array}{r}2 \\
13 \\
15 \\
15 \\
\cdots\end{array}$ & $\begin{array}{r}2 \\
19 \\
17 \\
9 \\
2\end{array}$ & $\begin{array}{r}4 \\
14 \\
2 \\
4\end{array}$ & $\begin{array}{l}\cdots \\
\cdots \\
9 \\
4\end{array}$ & $\begin{array}{r}\cdots \\
5 \\
7 \\
\cdots \\
{ }_{14}\end{array}$ & $\begin{array}{r}29 \\
139 \\
141 \\
53 \\
29\end{array}$ & $\begin{array}{r}26 \\
151 \\
r 34 \\
50 \\
30\end{array}$ & $\begin{array}{r}3 \\
-12 \\
7 \\
-1 \\
3\end{array}$ \\
\hline Totals.............. & I7 & $5 \mathrm{I}$ & 70 & 100 & $4 I$ & 49 & 24 & 13 & 26 & $39 \mathbf{r}$ & $39 \mathrm{I}$ & $\begin{array}{l}+13 \\
-13\end{array}$ \\
\hline
\end{tabular}


each rent group. ${ }^{1}$ Then the totals for the income groups were determined and placed in column $\mathrm{X}$. It will be noticed that these agree much more closely with the figures actually found by the enumeration than the results of either of the two previous estimates, the net number of misplacements being II, as contrasted with 53 and 42. An even better result was obtained for the 39I New York families with a random sample of $\mathrm{I} 60$, there being $\mathrm{I} 3$ misplacements net. If there were available for the test data involving a greater number of cases, the accuracy would doubtless be far greater.

A simple plan, then, of obtaining an approximate estimate of the distribution of incomes among the families of the United States is briefly this:

I. The distribution of incomes among farm families may be obtained from the data of the Census of Agriculture, if a new question calling for rent paid or interest on mortgage, be added to the schedule; and if, in compilation, the incomes of the farm families-computed by subtracting from the total value of products not fed to live stock, the wages and value of accommodation extended to farm laborers, the cost of feed and fertilizer purchased, and the rent or interest on the mortgage ${ }^{2}$ - be classified according to

1 For example, take column III. According to the first line of section $C$, the actual count showed thirty-four families paying rents of $\$ 70$ but less than $\$ g 0$. Section $B$ reveals the fact that sixty-nine per cent of these thirty-four families have incomes under $\$ 600$. Therefore, in column III, in the line for families having incomes below $\$ 600$, is placed the number twenty-three (sixty-nine per cent of thirty-four). Similarly, nineteen per cent (seven) had incomes of $\$ 500$ but under $\$ 800$, six per cent (two) had incomes of $\$ 800$ but under $\$ 1,000$, s:x per cent (two) had inccmes of $\$ 1,000$ but under $\$ 1,200$, and none had an income of $\$ 1,200$ or over. In the same way the other columns of section $C$ were filled out.

' Cost of insurance, seed, taxes, and depreciation of implements should be deducted if they can be obtained in the census. 
size and to the condition of the operator-whether he owns or hires his farm, and whether he possesses other farm property from which he secures a return.

2. The distribution of incomes among the non-agricultural households is to be determined by adding to the population schedule a question calling for the rent or the rental value of the house or tenement occupied by the family. A supplementary study must be made of a large number of households to ascertain exactly the distribution of incomes among the families in each rent group. Such a study could be made a year or two before the Census by the Bureau of Labor; enough families could be found willing to co-operate to give a sufficient basis for generalization. The results of this study should be tabulated separately for the small and large municipalities of each commonwealth. Similarly the Census returns should be separated for different-sized communities in each state, and for families in which the father-husband is and is not the only wage-earner.

The combination of the results of these two investigations would not be an exact summary of the distribution of incomes in the United States. The results would not likely be such as to aid in the development of wage theory; but the approximation would probably be so close to the facts that it would be a material aid in the solution of several great social questions. 


\section{BIBLIOGRAPHY}

\section{LIST OF PUBLICATIONS TO WHICH REFERENCE IS MADE IN THIS ESSAY}

I. Publications of the United States Government, Washington, D.C. A. Census Publications.

I. Tenth Census of the United States.

Public Indebtedness, Vol. VII.

2. Twelfth Census of the United States. Abstract of the Twelfth Census, 1904. Agriculture, Vols. V and VI, 1902. Manufactures, four volumes, 1900.

Special Reports-

Mines and Quarries, 1902.

Telephones and Telegraphs, 1902.

Employees and Wages, 1903.

Occupations, 1904.

Wealth, Debt, and T:xation, 1904.

Manufactures, 1905, four volumes.

Religious Bodies, 1906.

Central Electric Light and Power Stations, Ic07.

Express Business in the United States, 1907.

Statistics of Employees, Executive Civil Service of the Unitsd States, 1907. Bulletin No. 94.

Street and Electric Railways, 1907.

Telephone Industry, 1907.

The Shipping Industry. Mortality Statistics, annual.

3. Thirteenth Census of the United States. Advance Statement, General Data on Agriculture. Bulletin, Manufactures; United States.

B. Publications prepared by the Department of Commerce and Labor.

Bulletin of the Bureau of Labor. Bi-monthly.

Eighteenth Annual Report of the Commissioner of Labor. 1903. 
Investigation of Telephone Companies. Sen. Doc., 380, 61st Cong., and Ses., I9Io.

Report on Strike at the Bethlehem Steel Works. Sen. Doc., 521, 6Ist Cong., and Ses., I9Io.

Report on Condition of Woman and Child Wage-Earners in the United States. Sen. Doc., 645, 6Ist Cong., and Ses., I9II, 1912.

Statistical Abstract of the United States, annual.

C. Publications prepared by the Interstate Commerce Commission.

Sen. Doc., 188, 58th Cong., 3rd Ses. Ownership of $R . R$. Stock, 1905 .

Statistics of the Railways, annual.

Preliminary Abstract of Statistics of Common Carriers for Year ending June 30, I9I I (I912).

Statistics of Express Companies for Year Ending June 30, I9IO (I9II).

D. Publications prepared by the Treasury Department.

Report of the Comptroller of Currency.

Report of the Commissioner of Internal Revenue, annual.

E. Report of the Select Committee on Wages and Prices of

Commodities. Sen. Doc., 847, 6ist Cong., 3rd Ses., I9Ir.

F. Year Book, Department of Agriculture, annual.

G. Report, Commissioner of Education, annual.

II. Publications of State Authorities.

Connecticut, Report of Bank Commissioner, annual.

Illinois, Report of Bureau of Labor Statistics, biennial.

Iowa, Report of Bureau of Labor Statistics, biennial.

Kansas, Report of Bureau of Labor and Industry, annual.

Massachusetts, Statistics of Manufactures, annual.

Michigan, Report of the Bureau of Labor, annual.

Missouri, Report of the Burean of Labor Statistics, annual.

New Jersey, Report, Bureau of Statistics of Labor and Industries, annual.

New York, Report of Bureau of Labor Statistics, annual.

Report of Commissioner of Labor, annual.

Bulletin, Department of Labor, quarterly.

Report of the Comptroller, annual.

Census, 1865 .

Ohio, Report of the Burean of Labor Statistics, annual.

Pennsylvania, Report of the Secretary of Internal Affairs, Pt. III, Industrial Statistics, annual.

Tennessee, Report of the Burean of Labor Statistics and Mines, annual. 
Washington, Report of the Bureau of Labor Statistics and Factory Inspection, biennial.

Wisconsin, Report of the Bureau of Labor and Industrial Statistics, Pt. VIII, Manufacturing Returns, biennial.

III. Other Official Publications.

Annual Minutes of Various Methodist Episcopal Conferences.

Report of the Commissioners of His Majesty's Inland Revenue, annual.

IV. Private Publications.

Adams, H. C., Science of Finance. New York, I898, 1906.

Adams, T. S., and Sumner, H. L., Labor Problems. New York, 1905.

Beaulieu, Paul Leroy-, Essai sur la repartition des richesses, fourth ed. Paris, 1896 .

Chapin, Robert C., The Standard of Living in New York City. Charities Publication Committee, New York, 1909.

Clark, J. B., Essentials of Economic Theory. New York, 1907.

Johnson, J. F., Money and Currency. Boston, 1905.

Nearing, Scott, Wages in the United States. New York, I9II.

Ryan, J. A., A Living Wage. New York, 1906.

Seager, H. R., Introduction to Economics. New York, 1904, 1907.

Seligman, E. R. A, Principles of Economics. New York, 1905.

Spahr, Chas. B., Present Distribution of Wealth in the United States. New York, I896.

Streightoff, F. H., Standard of Living among the Industrial People of America. Boston, I9II.

Watkins, G. P., The Growth of Large Fortunes. Publications of the American Economic Association, 3rd Series, vol. vii, no. 4. New York, 1907.

Wright, C. D., ed., Report of Committee on Salaries, Tenure and Pensions of Public School Teachers in the United States. National Education Association.

Financial Red Book of America. New York, 1905.

V. Periodicals.

American Medical Compend.

American Year Book for $191 \mathrm{I}$.

The Financial Age.

Jahrbücher für National Oekonomie und Statistik.

Journal of the Royal Statistical Society.

Political Science Quarterly.

Quarterly Publications, American Statistical Association.

Wall Street Journal. 


\section{Additional References}

I. BoOKs

Brooks, J. G., The Social Unrest: Studies in Labor and Social Movements. New York, 1903.

Carver, T. N., Distribution of Wealth. New York.

Cherbuliez, J., Riche ou pauvre, exposition succincte des causes et des effets de la distribution actuelle des richesses sociales. Paris, 1840.

Clark, J. B., The Distribution of Wealth: a Theory of Wages, Interest, and Profit. New York, I899.

Collins, J. A., Distribution of Wealth in the United States. Sen. Doc., 75, 55th Cong., and Ses., I8g8.

Commons, J. R., The Distribution of Wealth. New York, I893.

Conrad, J., Handwörterbuch der Staatswissenschaften.

Giffen, R., Progress of the Working Classes. London, 1885.

Matthews, B. C., Our Irrational Distribution of Wealth. New York, I908.

Money, L. G. Chiozza-, M. P., Riches and Poverty. London, 1905.

Moore, H. L., Laws of Wages. New York, I9I I.

Mulhall, M. G., Industries and Wealth of Nations. New York, I896.

Pareto, W., Cours d'economie politique. Lausanne and Paris, I897.

Smart, W., Distribution of Income. London, I899.

Smith, R. Mayo-, The Science of Statistics, 2 vols. New York.

Sergeew, C., Die Verteilung der Güter in einigen Kantonen der Schweiz. Basel, I889.

Underwood, J. H., The Distribution of Ownership. Columbia University Studies in History, Economics and Public Law, New York, 1907.

Webb, A. D., New Dictionary of Statistics. New York, I9II.

Cost of Living in American Towns. Report into Working Class Rent, Housing, Wages, etc. Cd. 5609. London, I9Ir.

\section{ARTICLES}

Bowley, A. L., "Suggestions for the International Comparison of Wages by the Use of the Median." Journal Royal Statistical Society, vol. 72, p. 718. 1909 .

Cannan, E., "Division of Income." Quarterly Journal of Economics, vol. 19, p. 34I. 1905.

Carver, T. N., "How Ought Wealth to be Distributed?" Atlantic Monthly, vol. 97, p. 727.

Edwards, E. J., "The New Salaried Class." American Monthly Review of Reviews, vol. 32, p. 339. 1905.

Forbes, E. A., "Is the Doctor a Shylock?" World's Work, vol. I4, p. 8892. 1907. 
Giffen, R., "The Wealth of the Empire and How it Should be Used." J. R. S. S., vol. 66. 1903.

Goschen, G. J., "Increase of Moderate Incomes." J. R. S. S., vol. 50. 1887.

Harris, W. J., and Lake, K. A., "Estimates of the Realizable Wealth of the United Kingdom." J. R. S. S., vol. 69, p. 709. 1906.

Holmes, G. K., "How Far Should Family Wealth be Encouraged and Conserved?" American Journal of Sociology, vol. 14, p. 823. I909.

Hutchinson, J. G., "Can the Working Class Save?" Nineteenth Century, vol. 63, p. 285 .

Lorenz, M. O., "Methods of Measuring the Concentration of Wealth." American Statistical Association, vol. 9, p. 209. 1905.

Moore, H. L., "The Differential Law of Wages." J. R. S. S., vol. 70. p. 638.1907.

Moore, H. L., "Variability of Wages." Political Science Quarterly, vol. 22, p. 6I. 1907.

Persons, W. M., "Present Distribution of Wealth." Q. J. Ec., vol. 23, p. 4I6. 1909.

Powers, L. G., "The Assets of the United States." Am. J. Soc., vol. I4, p. I7I. 1908.

Watkins, G. P., "An Interpretation of Certain Statistical Evidence of Concentration of Wealth." Am. St. Ass'n., vol. II, p. 27. 1908.

Watkins, G. P., and Persons, W. M., "Measurement of Concentration of Wealth." $Q . J . E c$., vol. 23, p. I60. 1909.

Wright, C. D., "Are the Rich Growing Richer and the Poor, Poorer?" Atlantic, vol. 80, p. $300 . \quad$ I897.

"Amount and Distribution of Incomes," report of a committee of the Royal Statistical Society. J. R. S. S., vol. 74, p. 37. I9Io. 



\section{VITA}

ThE writer of this dissertation was born in Brooklyn, New York, 23 February, i886. Having prepared for college in the schools of Montclair, New Jersey, he attended Wesleyan University. $\mathrm{He}$ was awarded the degree of A. B. in 1909, and M. A. in I9lo for work in Economics and History under Professors Willard C. Fisher and George M. Dutcher, his master's essay being published as "The Standard of Living among the Industrial People of America." As a graduate student in Columbia University, he was Garth Fellow in I9IO-I I and Honorary Fellow in I9II-I2; he attended the lectures of Professors Edwin R. A. Seligman, John Bates Clark, Henry R. Seager, Henry R. Mussey, Henry L. Moore, Franklin H. Giddings, Alvin A. Tenney, Vladimir G. Simkhovitch, and Charles A. Beard, and was a member of the Seminars of Professors Seligman and Seager. He taught Mathematics in Bellefonte Academy during the academic year I909-I9Io, acted as a Special Agent for the New York State Department of Labor in the summer of 1912, and is at present Instructor in Economics at De Pauw University. 




RETURN TO the circulation desk of any

University of California Library

or to the

NORTHERN REGIONAL LIBRARY FACILITY Bldg. 400, Richmond Field Station

University of California

Richmond, CA 94804-4698

ALL BOOKS MAY BE RECALLED AFTER 7 DAYS

2-month loans may be renewed by calling

(415) 642-6753

1-year loans may be recharged by bringing books to NRLF

Renewals and recharges may be made 4 days prior to due date

DUE AS STAMPED BELOW

SEP

21992

FEB 251993

AUTODISCCIRC DEC 21 '92 
YC173660

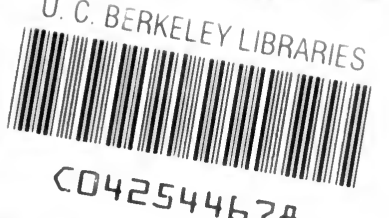


